\title{
Effects of a Floodwater-Retarding Structure on the Hydrology and Ecology of Trout Creek in Southwestern Wisconsin
}

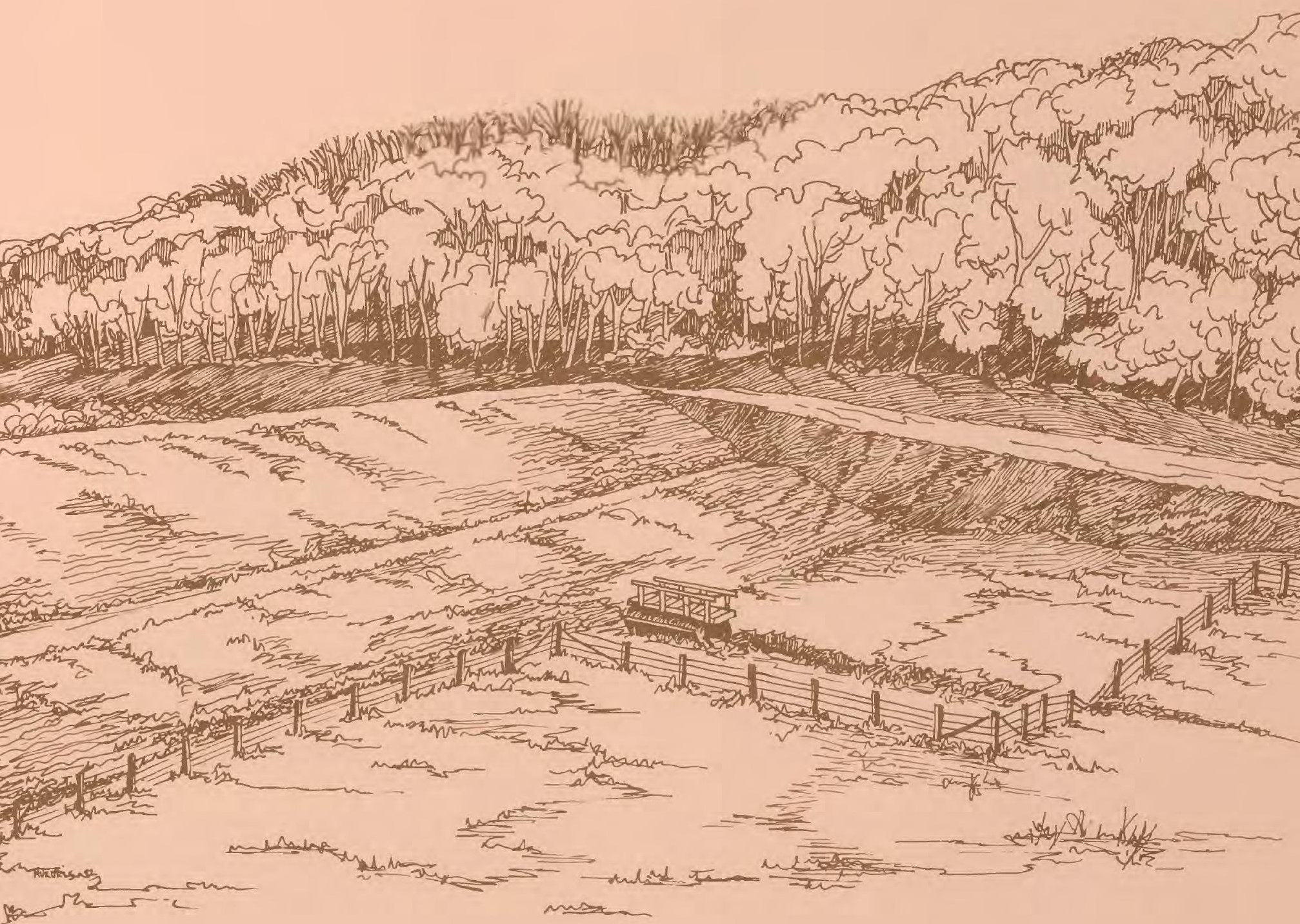




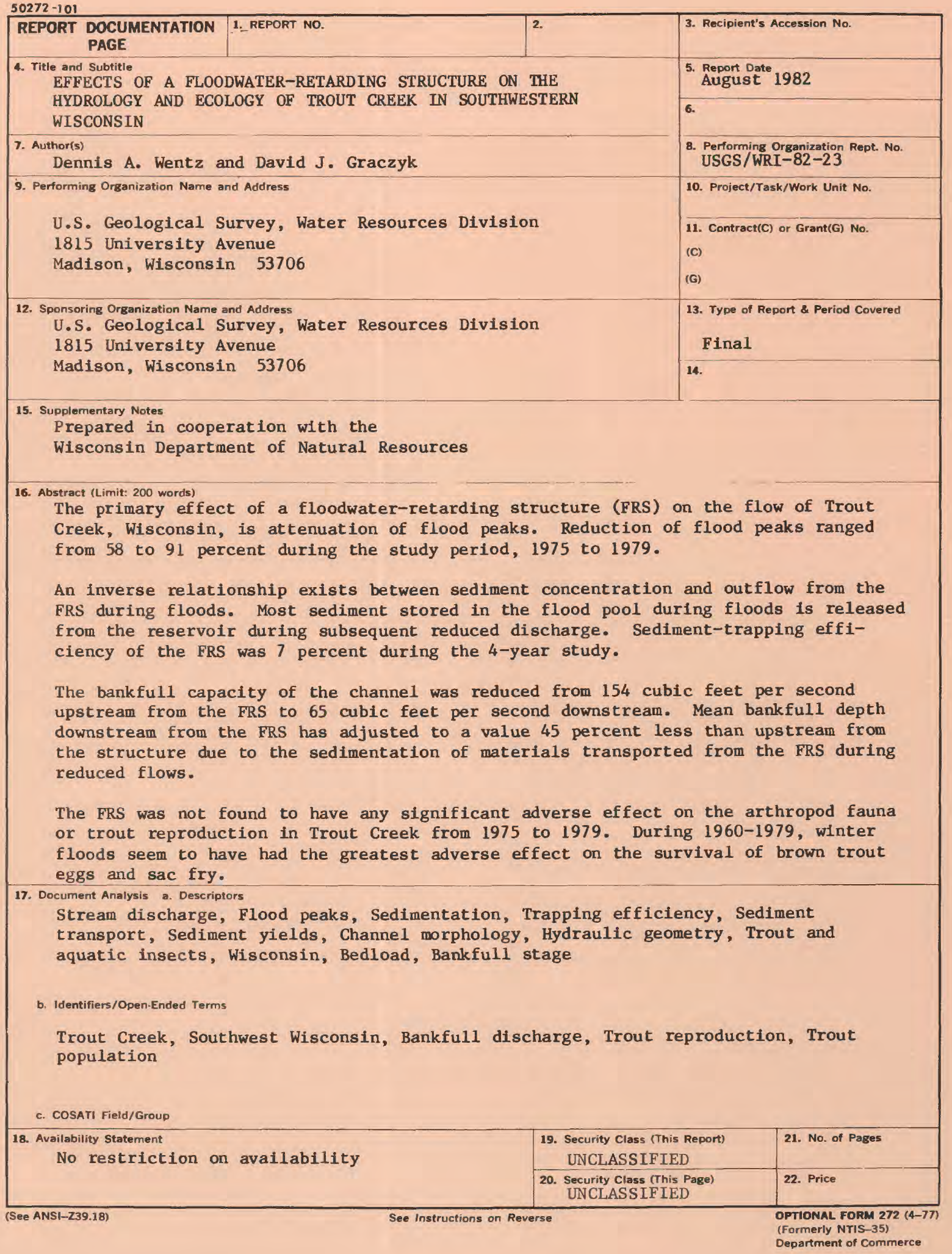




\title{
Effects of a Floodwater-Retarding Structure on the Hydrology and Ecology of Trout Creek in Southwestern Wisconsin
}

\author{
Edited by Dennis A. Wentz and David J. Graczyk \\ Background \\ By Steve Baima \\ Streamflow, Sedimentation, and Channel Morphology \\ By David J. Graczyk, Stephen J. Field, and Dennis A. Wentz \\ Arthropod Fauna \\ by William L. Hilsenhoff \\ Reproduction of Brown Trout \\ by Eddie L. Avery \\ Trout Populations \\ By O. M. Brynildson \\ Summary of Findings \\ By David J. Graczyk
}

\section{U.S. GEOLOGICAL SURVEY}

WATER RESOURCES INVESTIGATIONS 82-23

Prepared in cooperation with the

Wisconsin Department of Natural Resources

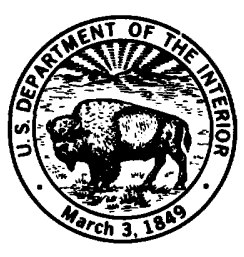

August 1982 


\title{
UNITED STATES DEPARTMENT OF THE INTERIOR
}

\author{
JAMES G. WATT, SECRETARY
}

\section{GEOLOGICAL SURVEY}

\author{
Dallas L. Peck, Director
}

For additional information write to:

U. S. Geological Survey

1815 University Avenue

Madison, Wisconsin 53706 


\section{CONTENTS}

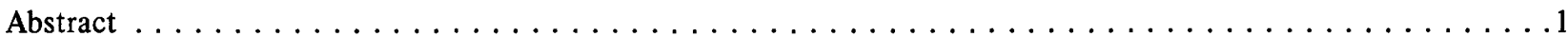

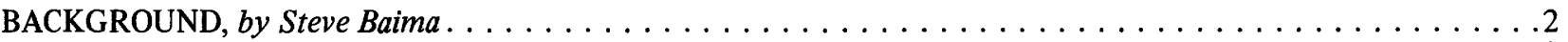

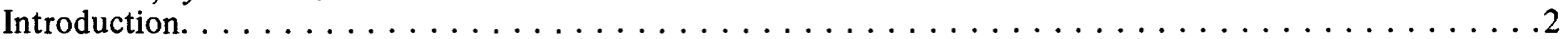

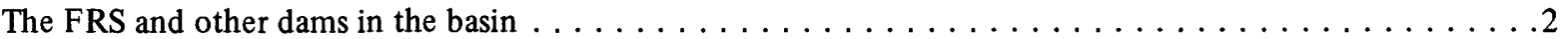

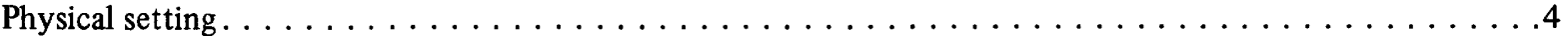

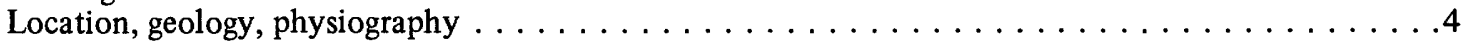

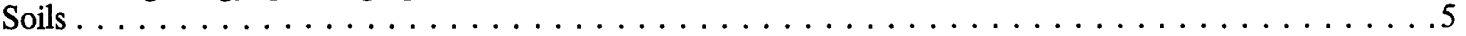

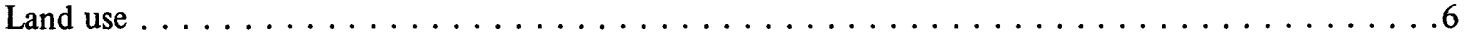

STREAMFLOW, SEDIMENTATION PROCESSES, AND CHANNEL MORPHOLOGY,

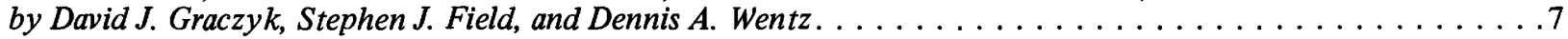

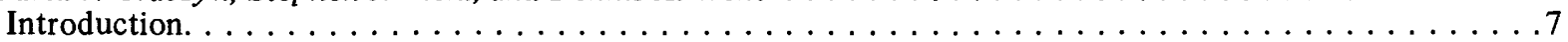

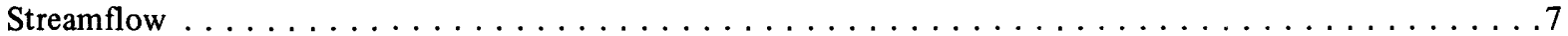

General description of the hydrologic system $\ldots \ldots \ldots \ldots \ldots \ldots \ldots \ldots \ldots \ldots \ldots \ldots$

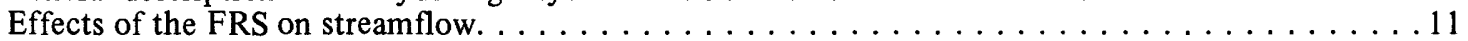

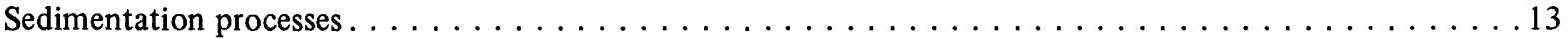

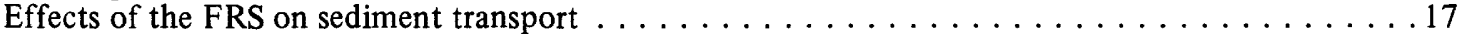

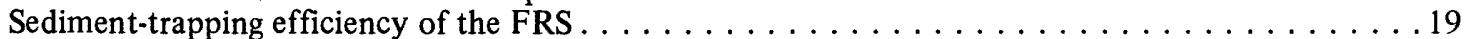

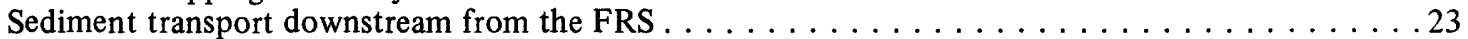

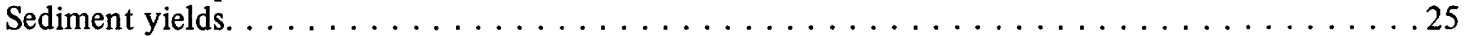

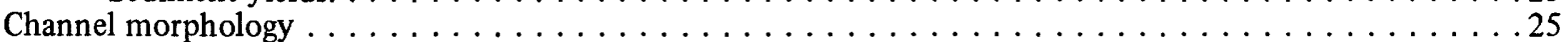

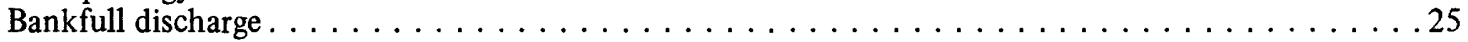

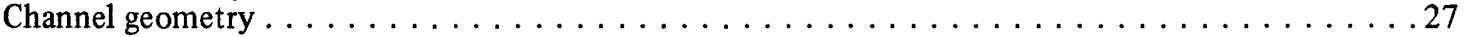

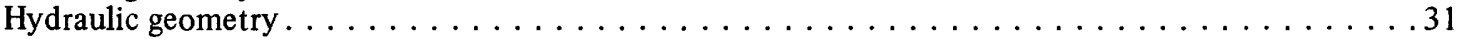

Channel morphology and drainage area $\ldots \ldots \ldots \ldots \ldots \ldots \ldots \ldots \ldots \ldots \ldots \ldots \ldots \ldots \ldots$

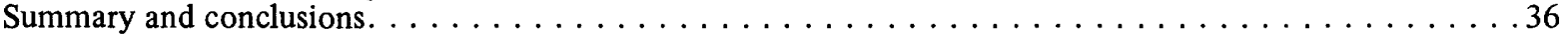

ARTHROPOD FAUNA, by William L. Hilsenhoff $\ldots \ldots \ldots \ldots \ldots \ldots \ldots \ldots \ldots \ldots \ldots \ldots \ldots \ldots \ldots \ldots$

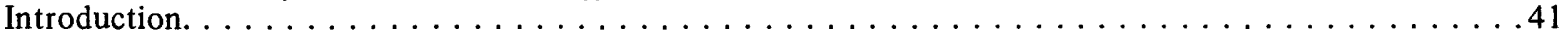

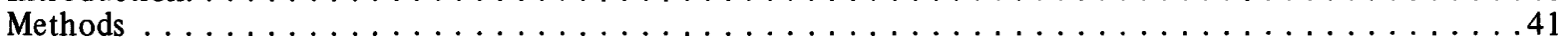

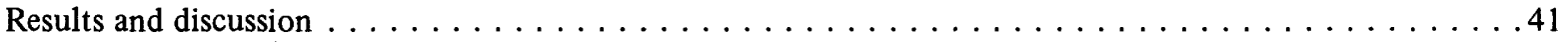

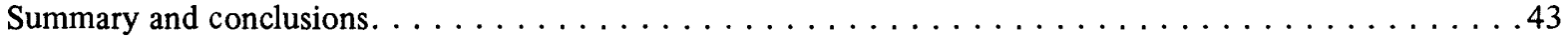

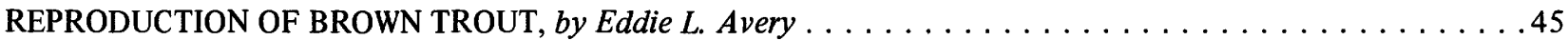

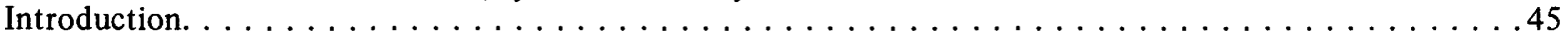

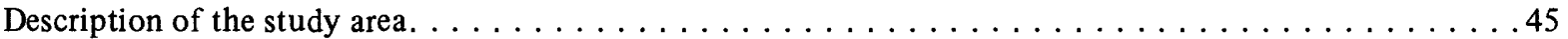

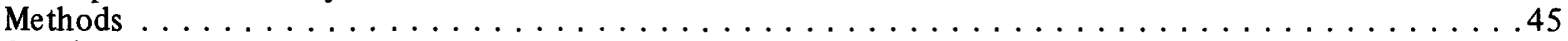

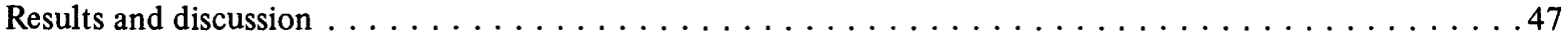

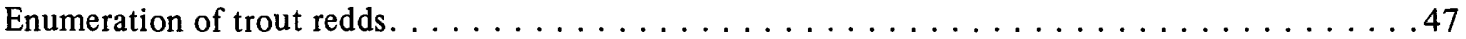

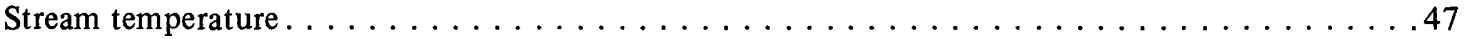

Substrate composition, water depth, and current velocity $\ldots \ldots \ldots \ldots \ldots \ldots \ldots \ldots$

Intragravel dissolved-oxygen concentrations $\ldots \ldots \ldots \ldots \ldots \ldots \ldots \ldots \ldots \ldots \ldots \ldots \ldots \ldots \ldots$

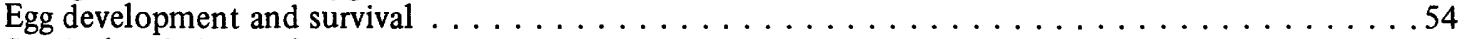

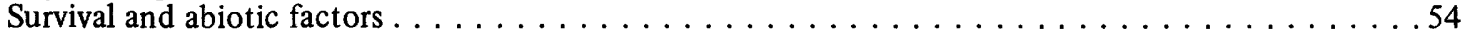

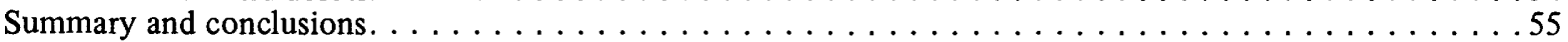

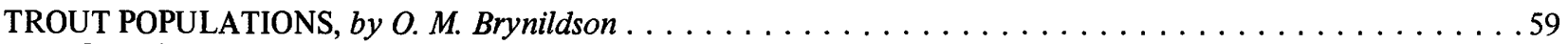

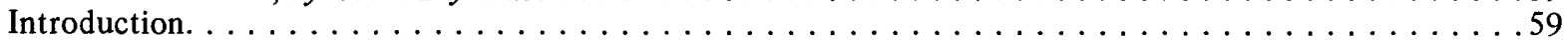

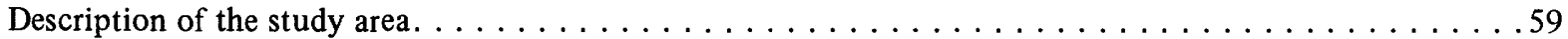

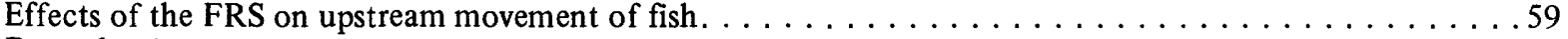

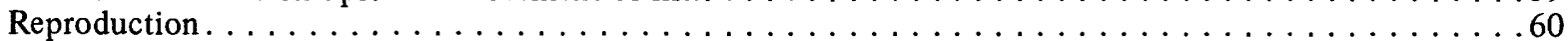

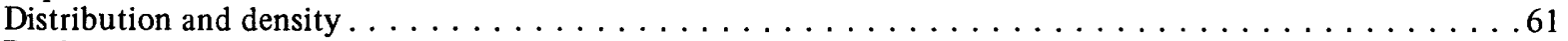

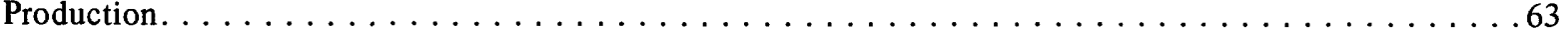

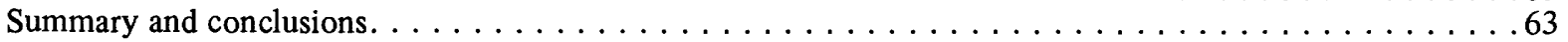

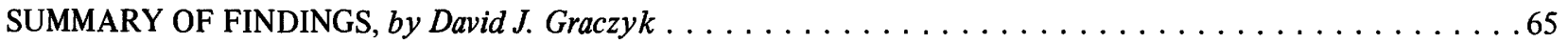

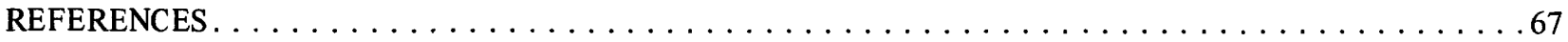




\section{ILLUSTRATIONS}

Figure 1. Map showing location of the Trout Creek basin in Wisconsin $\ldots \ldots \ldots \ldots \ldots \ldots \ldots \ldots \ldots$

2. Diagram showing profile of the floodwater-retarding structure (FRS) $\ldots \ldots \ldots \ldots \ldots \ldots \ldots \ldots$

3. Diagram showing plan view of the floodwater-retarding structure (FRS) $\ldots \ldots \ldots \ldots \ldots \ldots \ldots$

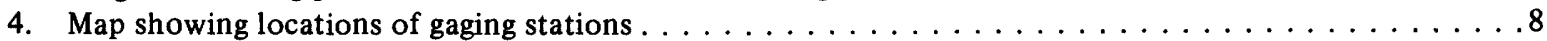

5. Photograph looking upstream at site $\mathrm{A} \ldots \ldots \ldots \ldots \ldots \ldots \ldots \ldots \ldots \ldots \ldots$

6. Photograph of outflow from the floodwater-retarding structure (FRS) at site B. . . . . . . . .9

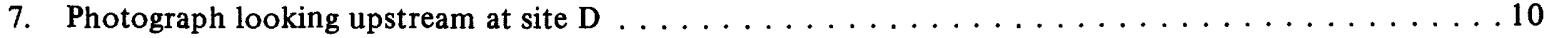

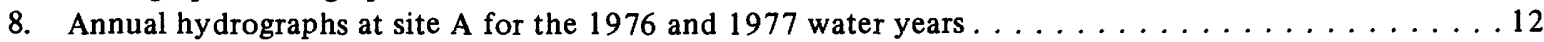

9. Hydrograph showing effect of the floodwater-retarding structure (FRS) on flood discharges, $1977 \ldots 14$

10. Hydrograph showing effect of the floodwater-retarding structure (FRS) on flood discharges, $1978 \ldots 15$

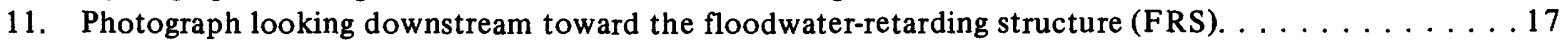

12. Photograph looking downstream toward the culvert under CountyHighway $T$, directly downstream

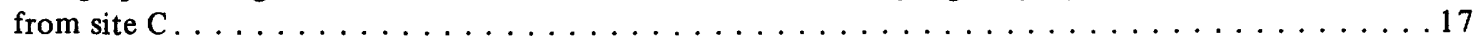

13. Hydrograph showing effect of the culvert under County Highway $T$ on flood discharges, 1977. . . . 18

14. Hydrographs showing discharge and daily-mean total-sediment concentrations in the outflow from the floodwater-retarding structure (FRS), $1976 \ldots \ldots \ldots \ldots \ldots \ldots \ldots$

15. Map showing locations and graphs showing shapes of channel cross sections upstream from the

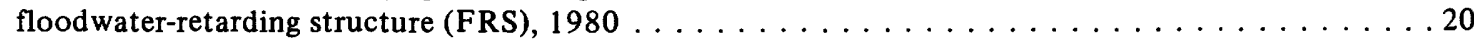

16. Graph showing cumulative total-sediment loads, $1976-79$ water years $\ldots \ldots \ldots \ldots \ldots \ldots \ldots \ldots 21$

17. Graph showing daily-mean total-sediment concentrations, 1979 water year . . . . . . . . . . 23

18. Graph showing median particle size of bed material, December $1977 \ldots \ldots \ldots \ldots \ldots \ldots$

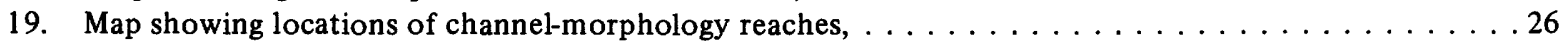

20. Diagrams showing representative cross sections from the channel-morphology reaches . . . . . . . 29

21. Diagrammatic representation of average channel geometry upstream and downstream from the

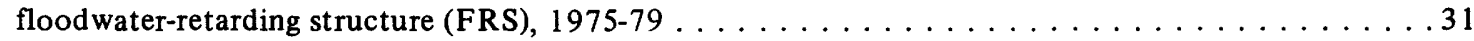

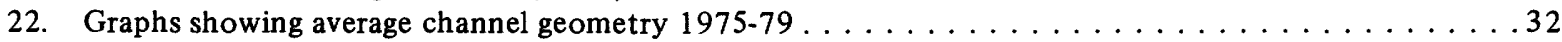

23. Map showing locations of miscellaneous channel-morphology sites, Trout Creek basin and vicinity . . . 33

24-30. Graphs showing:

24. Relationship of mean channel depth to bankfull discharge, Trout Creek basin and vicinity, 1975-79. . . . . . . . . . . . . . . . . . . . . . . . . . . 34

25. Relationship of channel width to bankfull discharge, Trout Creek basin and vicinity, 1975-79 . . 34

26. Relationship of channel cross-sectional area to bankfull discharge, Trout Creek basin and

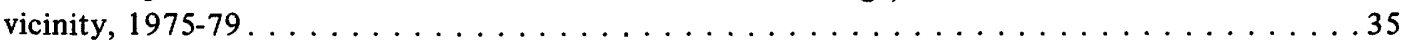

27. Relationship of bankfull discharge to drainage area, Trout Creek basin and vicinity, 1975-79 . . . 37

28. Relationship of mean channel depth at bankfull discharge to drainage area, Trout Creek basin

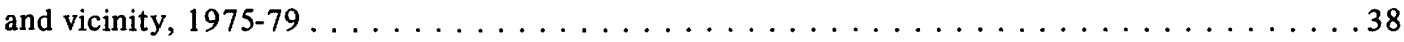

29. Relationship of channel width at bankfull discharge to drainage area, Trout Creek basin and

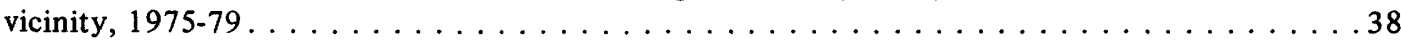

30. Relationship of channel cross-sectional area at bankfull discharge to drainage area, Trout Creek

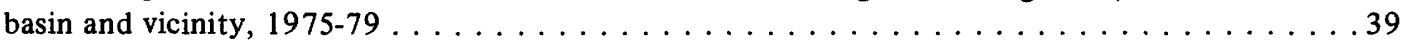

31. Map showing locations of sampling sites for collection of arthropod fauna . . . . . . . . . 42

32. Map showing locations of stations used in the trout repoduction and population studies . . . . . . .46

33. Graph showing chronology of redd construction by brown trout, $1976-77 \ldots \ldots \ldots \ldots \ldots \ldots$

34. Graph showing chronology of redd construction by brown trout, fall $1977 \ldots \ldots \ldots \ldots$. . . . . 47

35. Graph showing weekly mean stream temperatures upstream and downstream from the floodwaterretarding structure (FRS) during the fall $1976-77$ reproductive season $\ldots \ldots \ldots \ldots \ldots \ldots \ldots$ 


\section{TABLES}

Table 1. Total precipitation and departure from normal, Dodgeville, Wisconsin $\ldots \ldots \ldots \ldots \ldots \ldots \ldots$

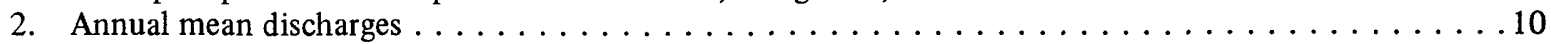

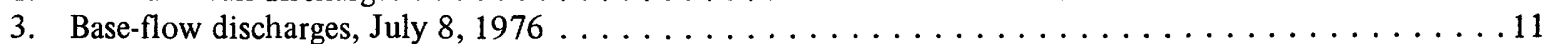

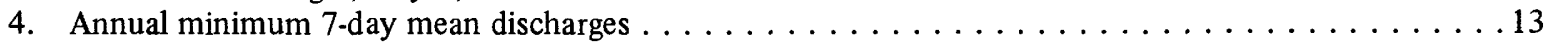

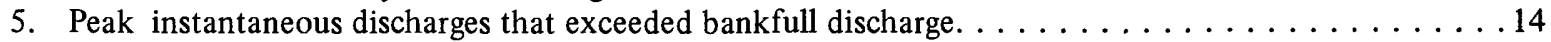

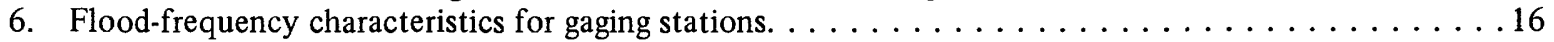

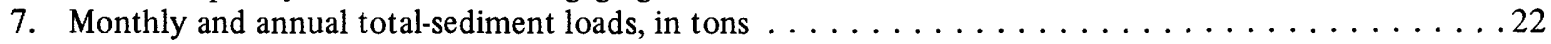

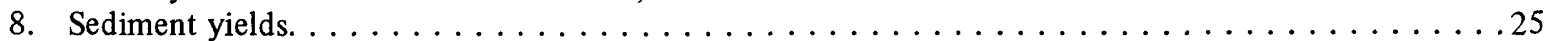

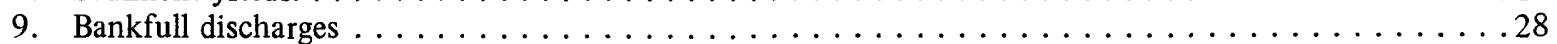

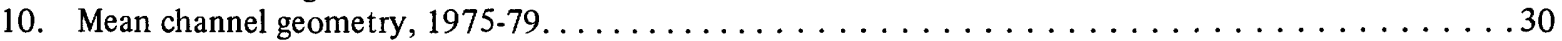

11. Hydraulic geometry at bankfull discharge, Trout Creek basin and vicinity, $1975-79 \ldots \ldots \ldots \ldots 33$

12. Comparisons of hydraulic geometry at bankfull discharge . . . . . . . . . . . . . . 36

13. Relationships of bankfull discharge and channel geometry to drainage area, Trout Creek basin and

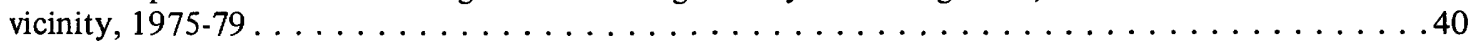

14. Comparisons of relationships of bankfull discharge and channel geometry to drainage area . . . . .40

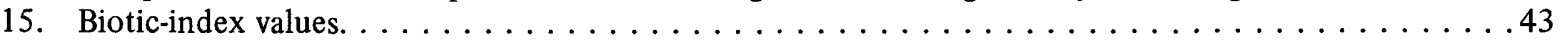

16. Numbers of each species of arthropod collected by site, month, and year . . . . . . . . . . . 44

17. Weekly mean stream temperatures at station 10 , downstream from the floodwater-retarding structure (FRS), and at station 21 upstream from the FRS . . . . . . . . . . . . 48

18. Water depths and current velocities over trout redds and percent, by weight, of redd substrates downstream and upstream from the floodwater-retarding structure (FRS), $1975-76 \ldots \ldots \ldots$. . . .49

19. Water depths and current velocities over trout redds downstream and upstream from the floodwater-

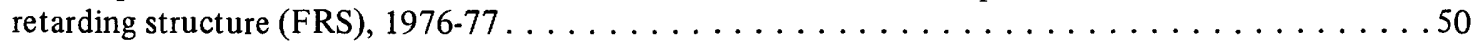

20. Intragravel dissolved-oxygen concentrations in trout redds downstream and upstream from the

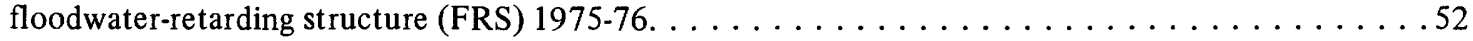

21. Intragravel dissolved-oxygen concentrations in trout redds downstream and upstream from the

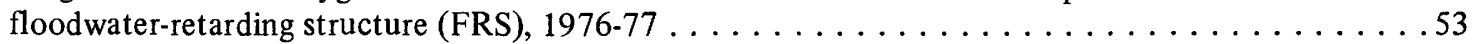

22 Embryo survival in trout redds downstream and upstream from the floodwater-retarding structure

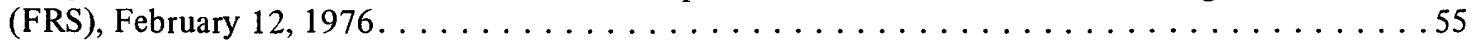

23. Embryo survival in trout redds downstream and upstream from the floodwater-retarding structure

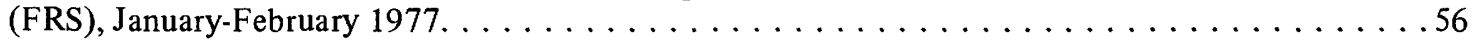

24. Embryo survival in trout redds downstream and upstream from the floodwater-retarding structure

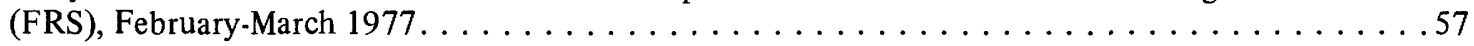

25. Potential reproduction and estimated survival of various year classes of wild brown trout to

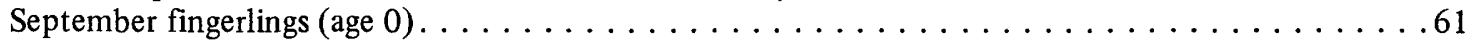

26. Number of wild brown trout fingerlings (age 0 ) per 100 square meters during September . . . . . .62

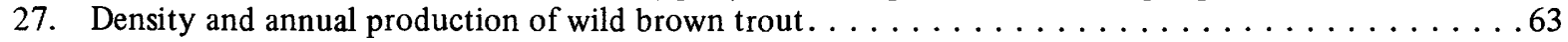




\section{CONVERSION TABLE}

For readers who prefer to use SI (metric) units rather than inch-pound units, conversion factors for terms used in this report are listed below.

$\begin{array}{ll}\text { Multiply } & \text { By } \\ \text { inch (in.) } & 25.40 \\ \text { foot (ft) } & 0.3048 \\ \text { square foot }\left(\mathrm{ft}{ }^{2}\right) & 0.09290 \\ \text { yard } & 0.9144 \\ \text { mile (mi) } & 1.609 \\ \text { square mile (mi2) } & 2.590 \\ \text { acre } & 0.4047 \\ \text { ton } & 0.9072 \\ \left.\text { ton per square mile (ton } / \mathrm{mi}^{2}\right) & 0.3503 \\ \text { foot per second }(\mathrm{ft} / \mathrm{s}) & 0.3048 \\ \text { cubic foot per second }(\mathrm{ft} 3 / \mathrm{s}) & 2.832 \times 10^{-2} \\ \text { cubic foot per second per square mile } & 0.01093\end{array}$

To obtain

millimeter (mm)

meter $(\mathrm{m})$

square meter $\left(\mathrm{m}^{2}\right)$

meter $(\mathrm{m})$

kilometer (km)

square kilometer $\left(\mathrm{km}^{2}\right)$

hectare

metric ton $(\mathrm{t})$

tonnes per square kilometer (tonnes $/ \mathrm{km}^{2}$ ) meter per second $(\mathrm{m} / \mathrm{s})$

cubic meter per second $\left(\mathrm{m}^{3} / \mathrm{s}\right)$

cubic meter per second per kilometer $\left[\left(\mathrm{m}^{3} / \mathrm{s}\right) \mathrm{km}^{2}\right]$

NOTE: Use or mention of a particular brand or model of equipment in this report does not imply a recommendation of its use by the U. S. Geological Survey 


\title{
Effects of a Floodwater-Retarding Structure on the Hydrology and Ecology of Trout Creek in Southwestern Wisconsin
}

\author{
Edited by Dennis A. Wentz and David J. Graczyk ${ }^{1}$
}

Abstract

\begin{abstract}
The primary effects of a floodwater-retarding structure (FRS) on the streamflow of Trout Creek, Wisconsin, are attenuation of flood peaks and extension of the time base of flood hydrographs. Reduction of flood peaks ranged from 58 to 91 percent during the study period from 1975 to $I 979$.

There is an inverse relation between sediment concentration and outflow from the FRS during floods. As water went into storage in the flood pool in March 1976, the daily-mean total-sediment concentration in the FRS outflow dropped from 562 to 147 milligrams per liter. Sediment concentration subsequently increased to 809 milligrams per liter as the discharge from the FRS dropped; concentrations remained more than $\mathbf{4 0 0}$ milligrams per liter for several weeks thereafter. Most sediment stored in the flood pool during flood flows is released from the reservoir during subsequent reduced discharge. Sediment trapping efficiency of the FRS was about 7 percent for the 4-year period of the study.
\end{abstract}

The bankfull capacity of the channel was reduced from 154 cubic feet per second upstream from the flood pool of the FRS to 65 cubic feet per second just downstream from the FRS. This latter discharge corresponds closely to the normal FRS outflow of 58 to 71 cubic feet per second during floods. Mean bankfull depth downstream from the FRS has adjusted to a value 45 percent less than upstream from the structure due to sedimentation of materials transported from the FRS during re- duced flows. The hydraulic geometry and relationships between channel geometry and drainage area indicate little effect of the FRS near the mouth of Trout Creek, 2.4 miles downstream from the FRS.

The arthropod fauna of Trout Creek is large and diverse. No effects of the FRS on these fauna were observed from April 1975 to October 1979.

From fall 1975 to winter 1978, the most important factor contributing to increased brown trout egg survival and fry emergence in Trout Creek during a single reproductive season is higher water temperatures in the upper reaches of the stream. The FRS was not found to have any significant effect on trout reproduction during that period.

From 1960 to 1979 , winter floods seem to have had the greatest adverse effect on the survival of brown trout eggs and sac fry. Although construction of the FRS has eliminated some spawning gravels in the flood pool owing to sedimentation, the wild trout have adapted by using spawning grounds above the flood pool more extensively and intensively. The FRS has not blocked the upstream migration of spawning trout, but it has eliminated similar migrations of fish that compete with and prey on the trout. Controlled streamflows downstream from the FRS have had a stabilizing influence on the limited trout reproduction in this region.

\footnotetext{
${ }^{1}$ U.S. Geological Survey, 1815 University Avenue, Madison, Wisconsin 53706.
} 


\title{
Background
}

\author{
By Steve Baima ${ }^{1}$
}

\section{INTRODUCTION}

This publication describes the findings of a study of Trout Creek, Iowa County, Wis. (fig. 1) from 1975 to 1979 . The study addresses impacts on the stream system caused by construction of a floodwater-retarding structure (FRS-8, hereafter referred to as FRS) in 1964. The FRS was built as a component of the Twin Parks Watershed Work Plan, a comprehensive project spanning $123 \mathrm{mi}^{2}$ in Iowa County. The Iowa County Soil and Water Conservation District sponsored the project, which was authorized by United States Public Law 566, the Watershed Protection and Flood Prevention Act.

The study was initiated to determine if placement, operation, and maintenance of the FRS were adversely affecting the trout population of Trout Creek. This was to be accomplished primarily by comparing conditions upstream from the FRS with those downstream, although some preconstruction data on trout populations also were available for comparison with postconstruction information. The FRS was built at a valley constriction that coincided with a stream reach used by trout for spawning. Objectives of the study were to evaluate the effects of the FRS on (1) streamflow, sedimentation processes, and channel morphology, (2) the arthropod fauna, (3) spawning environment and embryo survival of wild brown trout, and (4) the wild brown trout population.

Principal investigators in the study included the U.S. Geological Survey, the University of Wisconsin, and the Wisconsin Department of Natural Resources. Details concerning the methods and findings of individual investigators are reported in separate sections of this report. The U.S. Geological Survey concentrated on streamflow and sediment transport, including changes in channel morphology upstream and downstream from the FRS. The University of Wisconsin studied effects on the arthropod fauna of the stream, whereas the Wisconsin Department of Natural Resources studied effects on the trout population.
Trout Unlimited and the Iowa County Soil and Water Conservation District participated informally in an advisory capacity. The U.S. Soil Conservation Service shared project costs with the U.S. Geological Survey and the Wisconsin Department of Natural Resources and provided overall project review and consultation.

\section{THE FRS AND OTHER DAMS IN THE BASIN}

The FRS is an earthen dam, $34 \mathrm{ft}$ high, approximately $750 \mathrm{ft}$ long, and $200 \mathrm{ft}$ wide at the base (fig. 2). It was constructed to function as a dry dam, which means that water is impounded only during periods of rapid runoff. Base flow travels essentially uninterrupted through a principal spillway consisting of two pipes connected end to end. The pipes extend $226 \mathrm{ft}$ through the base of the dam on a 0.25 percent grade. The inlet pipe was designed to carry approximately $25 \mathrm{ft}^{3} / \mathrm{s}$ when flowing full. Runoff in excess of approximately $25 \mathrm{ft}^{3} / \mathrm{s}$ is stored temporarily in the flood pool of the FRS. Detention time of floodflows was designed to be relatively short. A 5.1-in., 6-hour storm (100-year frequency) has a design detention time of $\mathbf{4 8}$ to $\mathbf{7 2}$ hours.

A stilling basin, also called a plunge pool, receives water passing through the FRS before it reenters the natural channel (figs. 2 and 3). The stilling basin was installed to dissipate energy from the concentrated flow through the principal spillway.

Approximately $850 \mathrm{ft}$ of Trout Creek was directly altered by the construction of the FRS (fig. 3). About $280 \mathrm{ft}$ of stream was replaced by spillway pipe and the stilling basin. The remaining $570 \mathrm{ft}$ was lost to realignment to accommodate the inlet and outlet of the FRS.

Two other earthen dams constructed in the Trout Creek drainage basin (fig. 1) are referred to as MPS-7, a multiple-purpose floodwater-retarding and recreation reservoir that impounds Birch Lake,

\footnotetext{
${ }^{1}$ U.S. Soil Conservation Service, Technology Development and Application, P.O. Box 2890, Washington, D.C. 20013.
} 


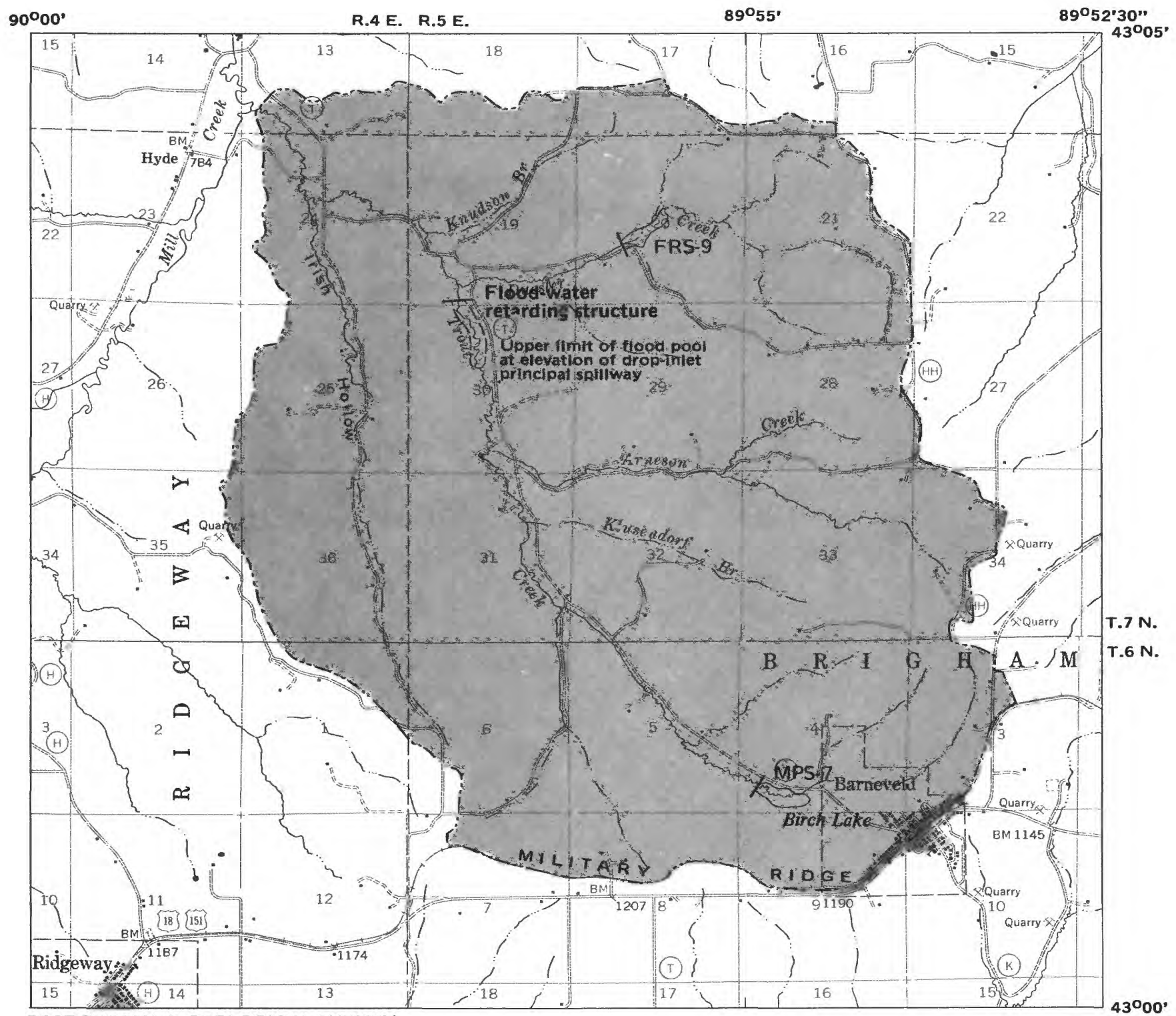

BASE FROM U. S. GEOLOGICAL SURVEY

BLUE MOUNDS $1: 62500,1962$

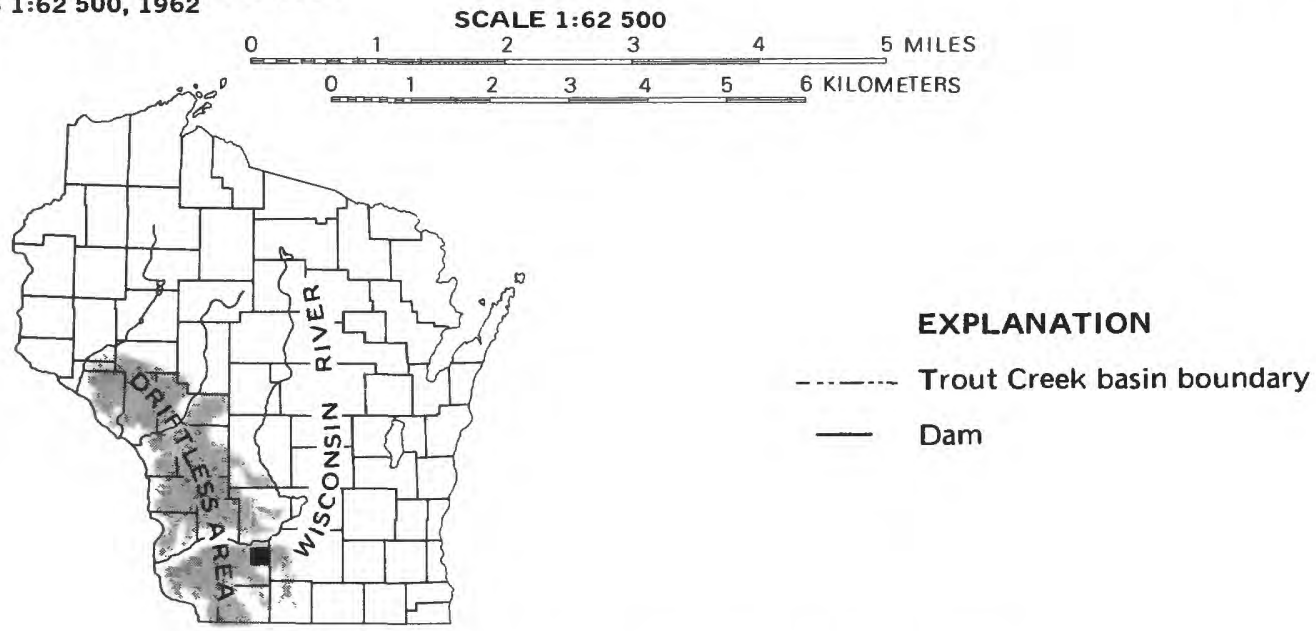

Figure 1. Location of the Trout Creek basin in Wisconsin. 


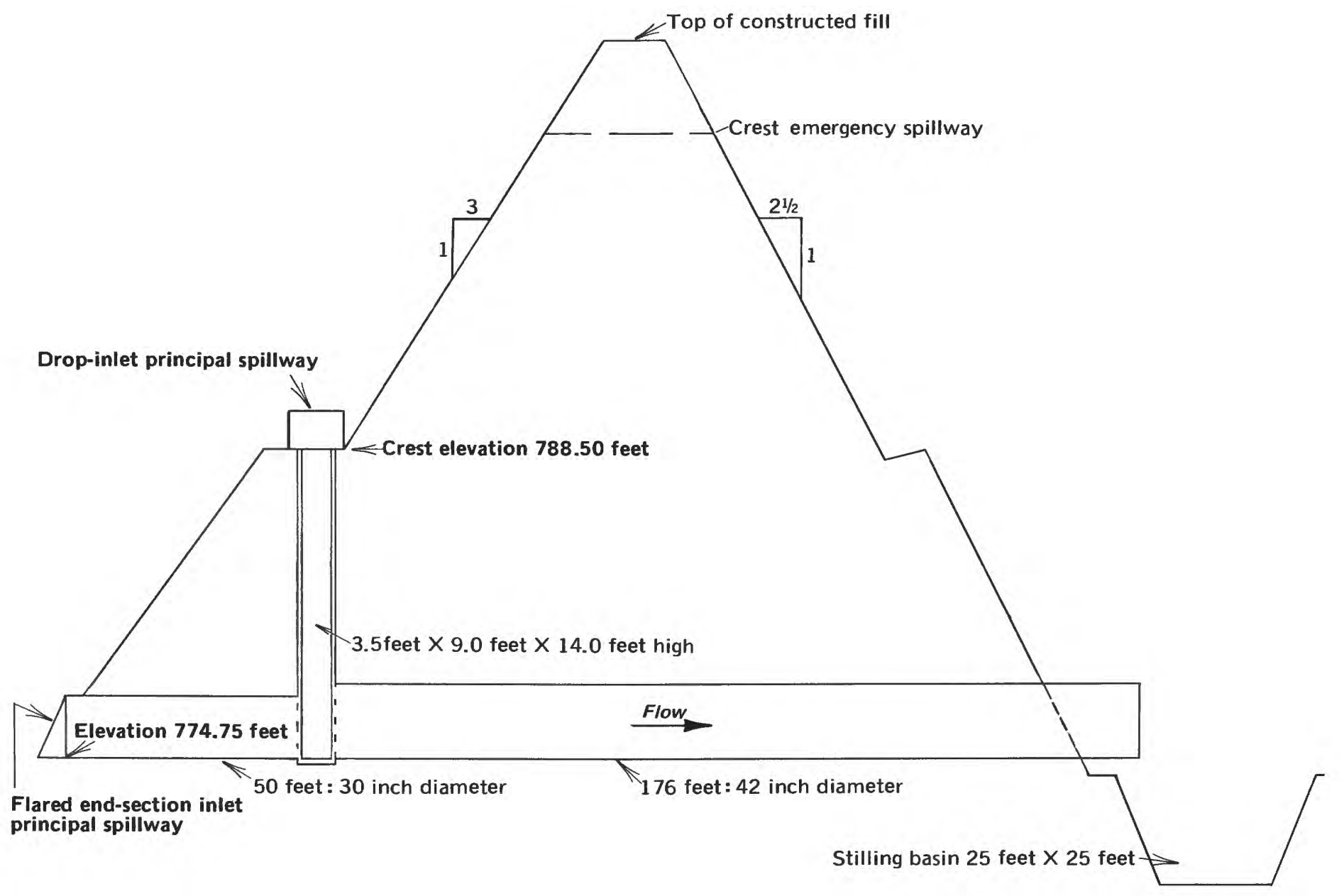

Figure 2. Profile of the floodwater-retarding structure (FRS).

and FRS-9, a single-purpose floodwater-retarding structure on Duesler Creek. Both structures impound permanent bodies of water, which have surface areas of 11 and 6 acres, respectively.

\section{PHYSICAL SETTING}

\section{Location, Geology, and Physiography}

Trout Creek is a spring-fed stream in southwestern Wisconsin (fig. 1). It is the largest tributary to Mill Creek, which, in turn, is tributary to the Wisconsin River.

The Trout Creek basin, approximately $17 \mathrm{mi}^{2}$, lies in the Western Upland geographic province
(Martin, 1932). The Western Upland corresponds roughly to the "Driftless Area", an area of Wisconsin that probably was not glaciated during the Pleistocene Epoch (Thwaites, 1956). The basin is characterized by valley flats between steep-walled ridges with rounded ridgetops; relief averages 200 ft.

The predominant topographic feature of the basin is Military Ridge. It constitutes the divide between the north-flowing tributaries of the Wisconsin River and the south-flowing streams tributary to the Rock and Mississippi Rivers (Martin, 1932).

The predominant bedrock underlying the basin is sandstone and dolomite of Cambrian and Ordovician age (Bean, 1949). 


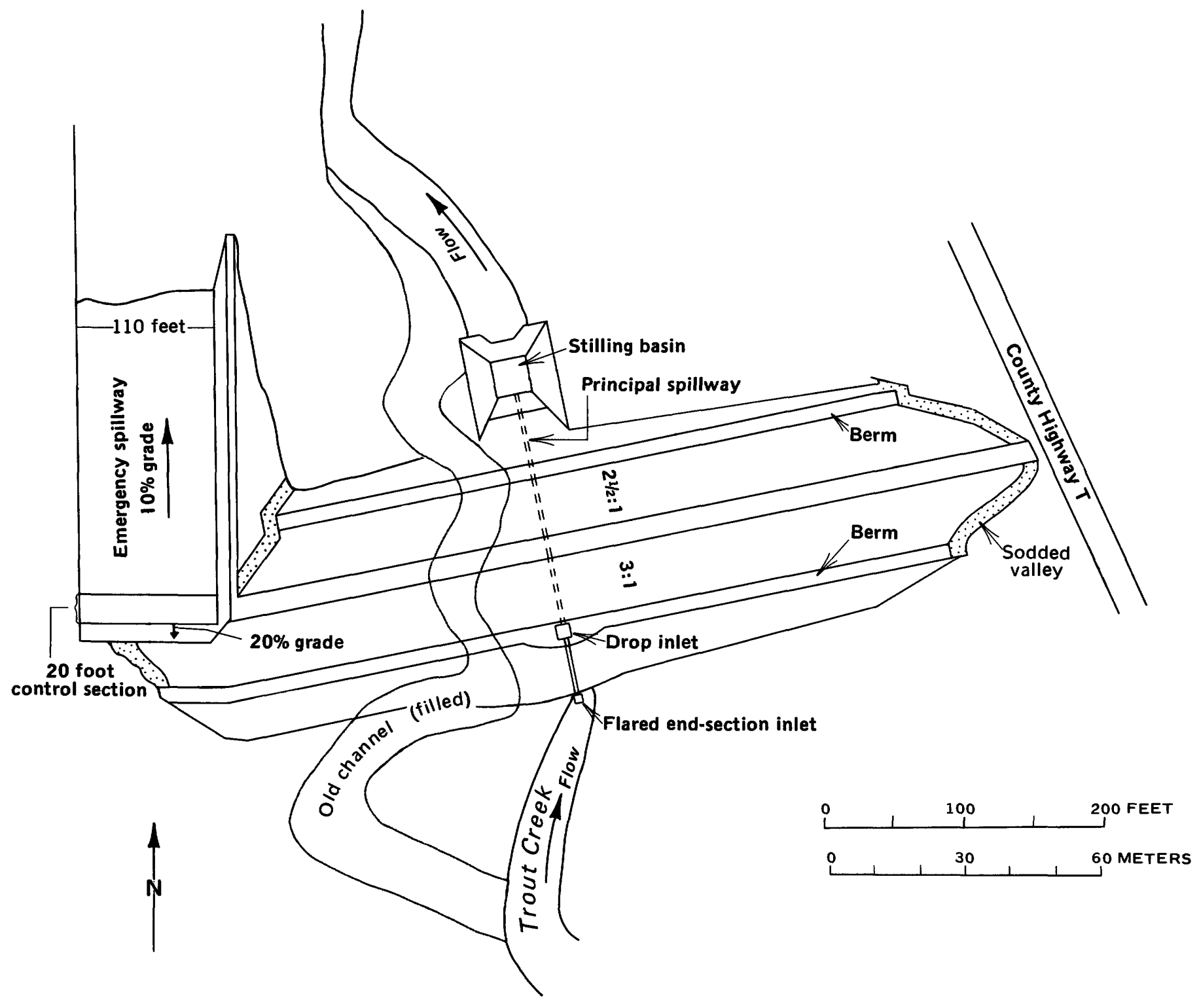

Figure 3. Plan view of the floodwater-retarding structure (FRS).

\section{Soils 1}

The soils along the valley floor of Trout Creek and its tributaries are nearly level (0-3 percent slope), deep (30-60 in.) silt loams. They range from well drained (water is removed readily, but not rapidly) to somewhat poorly drained (water is removed slowly enough to keep the soil wet for significant periods, but not all the time).
The valley sides consist predominantly of silt loams, with some silty and sandy soils and some areas of stony and rocky land. The soils are well drained to somewhat excessively drained (water is removed rapidly). They range from shallow (5-30 in.) to deep (30-60 in.), but most are moderately deep (20-50 in.). Most of the steep (20-65 percent slope) and very steep (45-65 percent slope) soils are moderately eroded (25-75 percent of the original A horizon has been lost). The area is dissected with many side drainages, some of which are gullies.

\footnotetext{
${ }^{1}$ Soil descriptors and their definitions are from U.S. Soil Conservation Service (1962).
} 
The upland ridgetops are primarily moderately deep silt loams and deep sandy soils, with some areas of shallow silt loams. The soils are sloping (5-16 percent slope) to moderately steep (10-30 percent slope), and most are well drained.

Soils on the upland areas and valley sides are moderately permeable $(0.80-2.50 \mathrm{in} . / \mathrm{h})$ and have moderate water intake rates. The combination of moderate intake rate and slope contributes to rapid runoff and excessive soil loss.

\section{Land Use}

Land use in the Trout Creek basin is primarily agricultural, woodlots, and recreational. The agricultural uses include crop farming--mainly corn, oats, and hay--and grazing for feeder and dairy cattle (Cheetham and Wilke, 1976). Crop farming is limited to the valley bottoms and the rounded ridgetops. Many small woodlots are on the steep valley sides. The recreational use is concentrated around Birch Lake, which is used for swimming and fishing. The Wisconsin Department of Natural Resources has an easement along Trout Creek that can be used for hunting and fishing. Annually, about 1,500 fishermen fish the Trout Creek basin (Cliff Brynildson, oral commun., 1980). 


\title{
Streamflow, Sedimentation Processes, and Channel Morphology
}

\author{
By David J. Graczyk, Stephen J. Field, and Dennis A. Wentz ${ }^{1}$
}

\section{INTRODUCTION}

The study of the hydrology of the Trout Creek basin began in 1975 in cooperation with the Wisconsin Department of Natural Resources and the U.S. Soil Conservation Service. The purpose of the study was to determine the effects of a floodwaterretarding structure (FRS) on the streamflow, sedimentation processes, and channel morphology of Trout Creek. The assistance of R. S. Grant in the planning and initial data-collection phases is greatly appreciated.

\section{STREAMFLOW}

Streamflow was monitored at four sites (fig. 4) during water years 1976 through 1978, and at three of these sites (A, B, and D, described below) during the 1979 water year. One of the stream-gaging stations, 05406573 (site A, fig. 5), was located 0.5 mi upstream from the maximum limit of the storage pool behind the FRS; the drainage area above this site is $8.37 \mathrm{mi}^{2}$. Outflow from the FRS (site B, fig. 6) was determined from stage measurements immediately upstream from the FRS at station 05406574 , which has a drainage area of $9.02 \mathrm{mi}^{2}$. The other two gaging stations, 05406575 (site $C$ ) and 05406577 (site D, fig. 7), were downstream from the FRS and have drainage areas of $12.1 \mathrm{mi}^{2}$ and 13.5 $\mathrm{mi}^{2}$, respectively.

Each gaging station was equipped with waterlevel recording equipment. Discharge measurements were made every 4 to 6 weeks--more often during high flow--to define a stage-discharge relationship for each site. All streamflow data were collected in accordance with approved procedures of the U.S. Geological Survey (Buchanan and Somers, 1968, 1969); the data have been published separately (U.S. Geological Survey, 1977, 1978, 1979, 1980).

\section{General Description of the Hydrologic System}

Long-term precipitation data from Dodgeville, Wis.--15 mi southwest of the basin--define a normal annual total precipitation of 33.04 in. for 1941-70 (Environmental Data Service, 1973). Total precipitation and departure from normal for the 1975 through 1979 water years are shown in table 1 . The 1976 and 1977 water years are, respectively, the driest and wettest years during the study. During the 1976 water year, Dodgeville received 25.86 in. total precipitation (Environmental Data Service, 1974-79), with a departure from normal of -7.18 in. In 1977, Dodgeville received 39.36 in. total precipitation (Environmental Data Service, 1974-79), with a departure from normal of $+6.32 \mathrm{in}$.

Annual hydrographs for the 1976 and 1977 water years at site $\mathbf{A}$ are shown on figure 8 . This figure and the annual mean discharges during the study (table 2) show that the average streamflows during the driest water year (1976) are greater than during the wettest water year (1977). The primary reason for this is the high base flow of Trout Creek. During water year 1975, precipitation was near normal (table 1) and the ground-water system con-

Table 1. Total precipitation and departure from normal, Dodgeville, Wis.

[Based on data from the Environmental Data Service (1973, 1974-79)]

Water year

Total precipitation

(in.)

30.65

25.86

39.36

38.57

29.66
1975

1976

1977

1978

1979
Departure from normal

(in.)
$-2.39$

$-7.18$

$+6.32$

$+5.53$

$-3.38$

${ }^{1}$ U.S. Geological Survey, 1815 University Avenue, Madison, Wisconsin 53706. 


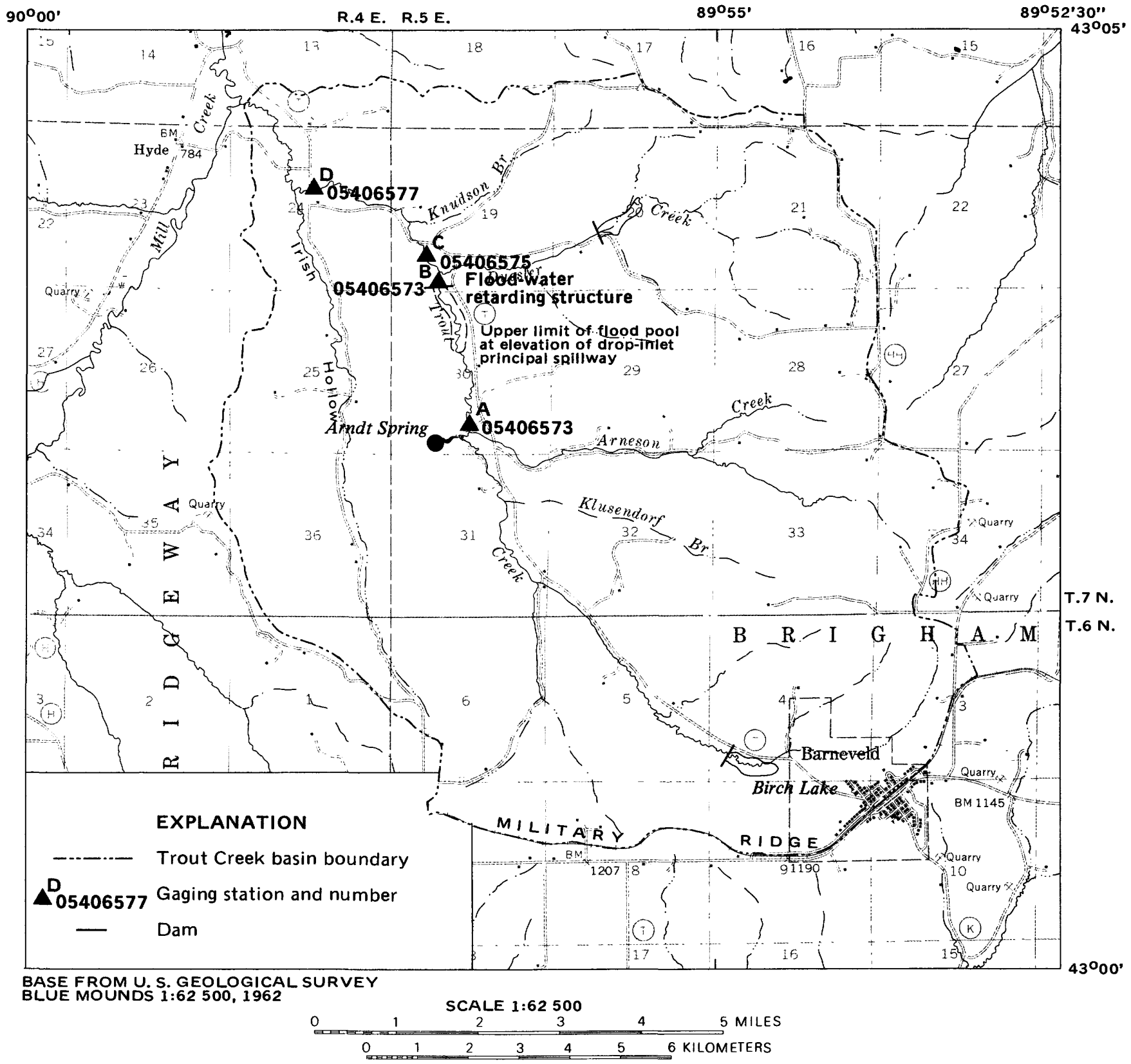

Figure 4. Locations of gaging stations.

tained approximately normal amounts of water. Much of this ground water was depleted as base flow during the dry 1976 water year. The above average precipitation of water year 1977 was utilized primarily to replenish the depleted ground water, and the base-flow contribution during this water year was less than during the previous (1976) water year.

Table 3 presents data that illustrate the groundwater contribution to Trout Creek during base flow.
Above site A, the average base-flow discharge on July 8,1976 , was $0.66\left(\mathrm{ft}^{3} / \mathrm{s}\right) / \mathrm{mi}^{2}$, for $8.37 \mathrm{mi}^{2}$ of drainage area. The base-flow discharge in the reach immediately above site $\mathbf{A}$ is expected to be considerably higher, as Arndt Spring--the largest known spring in the basin--enters Trout Creek in this area (fig. 1). However, no streamflow data are available upstream from Arndt Spring for comparison.

In the reach between site $A$ and site $B$, the base flow of Trout Creek was $2.0\left(\mathrm{ft}^{3} / \mathrm{s}\right) / \mathrm{mi}^{2}$ on July 8 , 


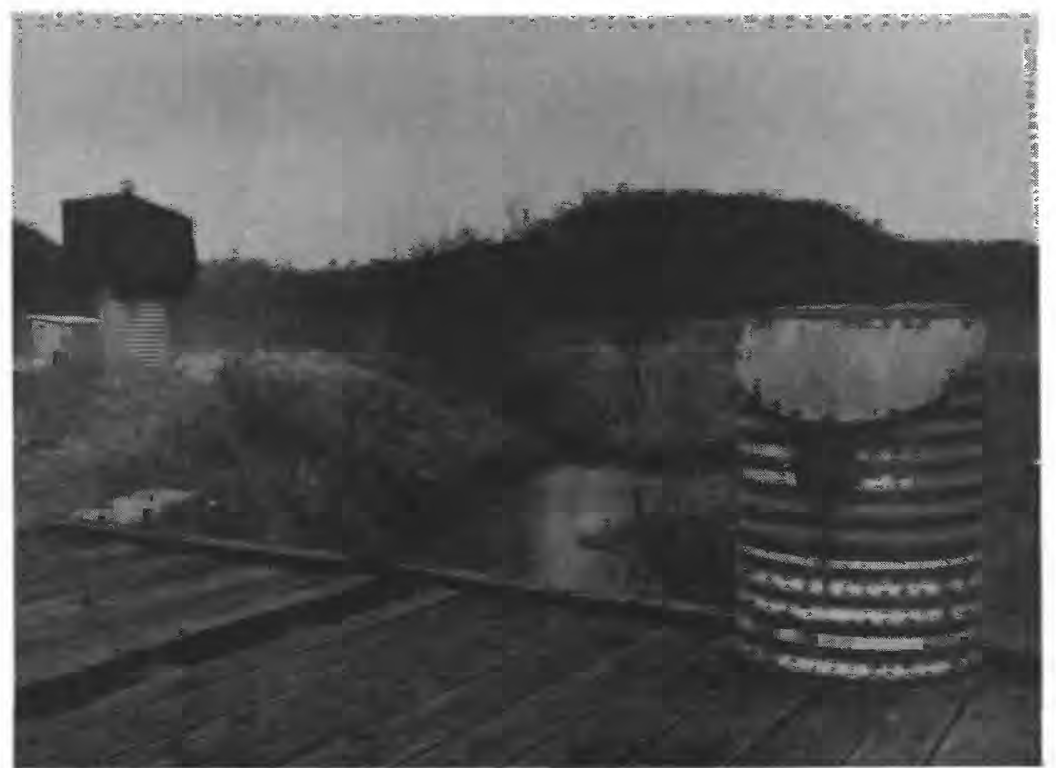

Figure 5. Looking upstream at site A.

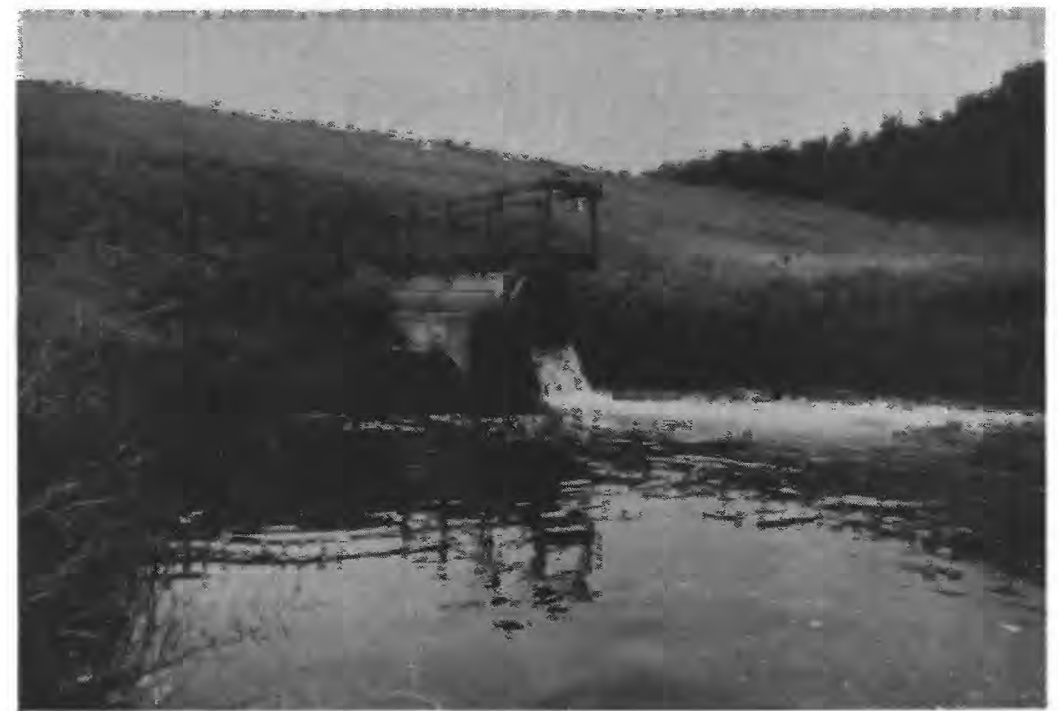

Figure 6. Outflow from the floodwater-retarding structure (FRS) at site B. 


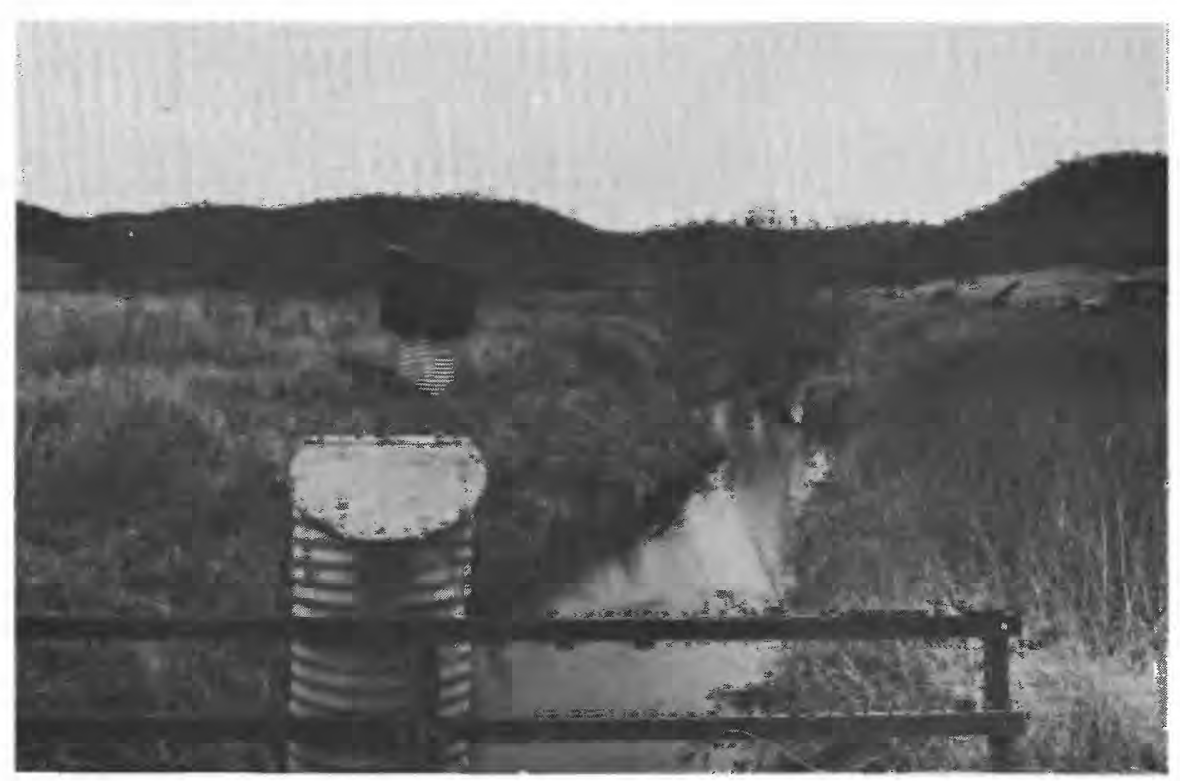

Figure 7. Looking upstream at site D.

Table 2. Annual mean discharges.

$$
\text { Discharge }\left(\mathrm{ft}^{3} / \mathrm{s}\right)
$$

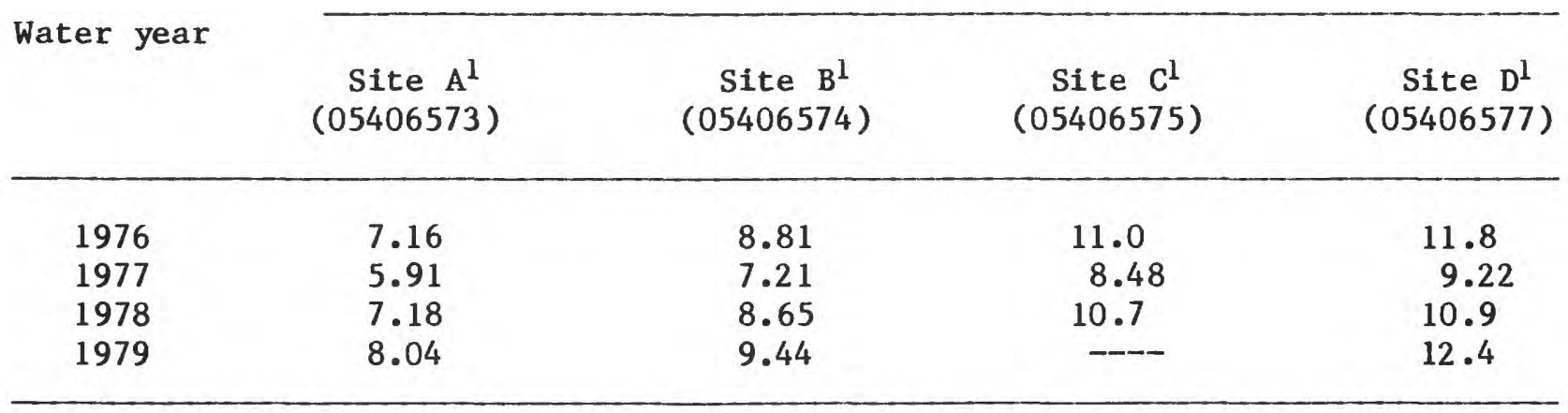

${ }^{1}$ See figure 4 for locations. 
Table 3. Base-flow discharges, July 8, 1976.

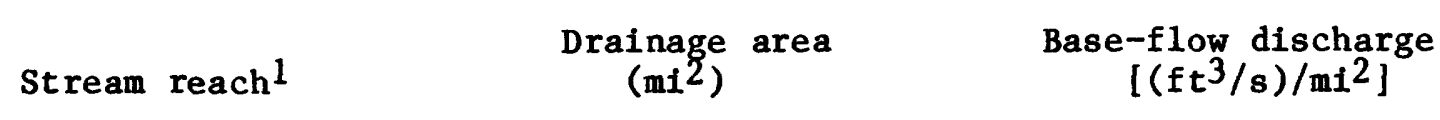

$\begin{array}{lrc}\text { Above site A } & 8.37 & 0.66 \\ \text { Site A to site B } & .65 & 2.0 \\ \text { Site B to site C } & 3.08 & .52 \\ \text { Site C to site D } & 1.40 & .071\end{array}$

${ }^{1}$ See figure 4 for locations of sites.

1976. This is the highest value measured and results from numerous springs discharging to the stream in this reach. Base-flow discharges decreased considerably in the two reaches downstream from site B, indicating progressively decreasing ground-water contributions in the lower part of the basin.

The annual minimum 7-day mean flows below which the stream discharge will fall on the average of once in 2 years $\left(Q_{7,2}\right)$ and 10 years $\left(Q_{7,10}\right)$ have been estimated for sites A, B, C, and D by Gebert (1978). These estimates were based on graphical relationships of discharge measurements at the four sites to the long-term record at station 05406500 , Black Earth Creek at Black Earth, $15 \mathrm{mi}$ to the northeast. During the study period, the recorded annual minimum 7-day mean flows were slightly higher than Gebert's (1978) estimates; both values are shown in table 4 for comparison. Because the annual minimum 7-day mean flows are based on the climatic year (April through March), only 3 years of data were available for sites A, B, and D, and only 2 years were available for site $C$.

Peak instantaneous discharges that exceeded a reference streamflow are shown in table 5 for sites A, B, and D for the period of study. The reference chosen is the bankfull discharge at each site (table 9). Site $C$ is not included because of the shorter period of record and because of difficulties in determining bankfull discharge at this site. The peak recorded discharge for the 4-year period of the study was $1,080 \mathrm{ft}^{3} / \mathrm{s}$ at site A on June 17,1978 . Peak discharges at sites $B$ and $D$ were 188 and 120 $\mathrm{ft}^{3} / \mathrm{s}$, respectively, also on June 17,1978 . The peak discharge of $120 \mathrm{ft}^{3} / \mathrm{s}$ at site $D$ also occurred on March 12, 1976.

A log-Pearson Type III flood-frequency analysis (U.S. Water Resources Council, 1977) was used to estimate the magnitudes and frequencies of the annual flood peaks at sites A, B, and D. The results of this analysis are shown in table 6 for the 2- and 5-year recurrence intervals; the associated discharges are designated $Q_{2}$ and $Q_{5}$. For a log-Pearson Type III flood-frequency analysis to be acceptable, the U.S. Water Resources Council (1977) recommends 10 years or more of record. The period of record for the Trout Creek sites is only 4 years; however, the flood-frequency characteristics provide at least an approximation of flood discharges.

\section{Effects of the FRS on Streamflow}

The primary effects of the FRS on streamflow are to attenuate flood peaks and to extend the time of flood duration. For example, the July 18, 1977, storm resulted in a discharge of $770 \mathrm{ft}^{3} / \mathrm{s}$ at site $\mathrm{A}$, with a corresponding peak discharge of $71 \mathrm{ft}^{3} / \mathrm{s}$ at site $B$ (fig. 9). This is a 91-percent reduction in peak discharge. The highest discharge recorded during the study at site $A$ was $1,080 \mathrm{ft}^{3} / \mathrm{s}$ on June 17,1978 (fig. 10). Site B had a peak discharge of $188 \mathrm{ft}^{3} / \mathrm{s}$ on this same date--a reduction of 83 percent. The smallest reduction of a flood peak during the study was $5 \dot{8}$ percent on February 27, 1976 (table 5).

As mentioned above, the FRS also extends the time required for the discharge to return to base flow. For example, at 2000 hours on July 19, 1977, the discharge at site $A$ was $6.4 \mathrm{ft}^{3} / \mathrm{s}$, which is only 8.5 percent more than the prestorm discharge of 5.9 $\mathrm{ft}^{3} / \mathrm{s}$ at 2000 hours on July 17 (fig. 9). At site B the discharge at 2000 hours on July 19 was still 56 percent higher than the corresponding prestorm discharge (fig. 9).

The FRS begins to pond water when the inflow discharge is about $22 \mathrm{ft}^{3} / \mathrm{s}$ at a gage height of $7.45 \mathrm{ft}$ above arbitary datum. This compares favorably to the design discharge of $25 \mathrm{ft}^{3} / \mathrm{s}$. Discharges from the FRS normally ranged from 58 to $71 \mathrm{ft}^{3} / \mathrm{s}$ for most storms. Only on June $17-18,1978$, did water 


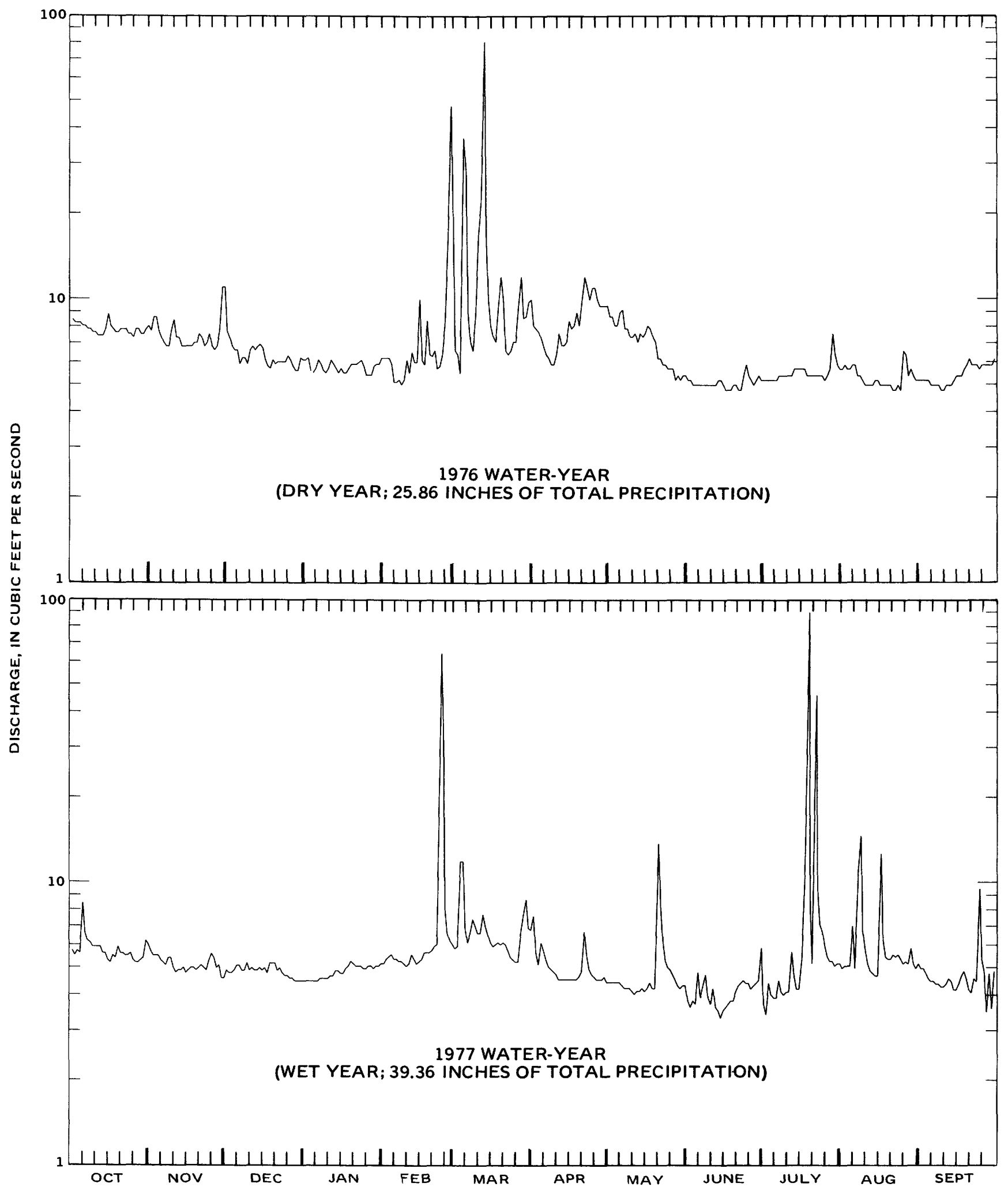

Figure 8. Annual hydrographs at site $A$ for the 1976 and 1977 water years. 
Table 4. Annual minimum 7-day mean discharges.

\begin{tabular}{|c|c|c|c|c|}
\hline \multirow[b]{2}{*}{$\begin{array}{l}\text { Climatic } \\
\text { year }\end{array}$} & \multicolumn{4}{|c|}{ Measured discharge $\left(\mathrm{ft}^{3} / \mathrm{s}\right)$} \\
\hline & $\begin{array}{l}\text { Site } A^{l} \\
(05406573)\end{array}$ & $\begin{array}{l}\text { Site B } \\
(05406574)\end{array}$ & $\begin{array}{l}\text { Site } c^{l} \\
(05406575)\end{array}$ & $\begin{array}{l}\text { Site } D^{1} \\
(05406577)\end{array}$ \\
\hline $\begin{array}{l}1977 \\
1978 \\
1979\end{array}$ & $\begin{array}{l}4.5 \\
3.7 \\
4.8\end{array}$ & $\begin{array}{l}5.6 \\
5.0 \\
6.8\end{array}$ & $\begin{array}{l}6.2 \\
5.7 \\
-\end{array}$ & $\begin{array}{l}7.0 \\
5.9 \\
7.9\end{array}$ \\
\hline
\end{tabular}

Low-flow frequency

symbol representing

associated discharge

Estimated discharge ${ }^{2}\left(\mathrm{ft}^{3 / \mathrm{s}}\right)$

$\begin{array}{lllll}Q 7,2 & 3.6 & 4.6 & 5.5 & 5.4 \\ Q 7,10 & 2.9 & 3.8 & 4.4 & 4.2\end{array}$

${ }^{1}$ See figure 4 for locations.

${ }^{2}$ Gebert (1978).

behind the FRS discharge into the drop-inlet principal spillway (fig. 11), an elevation corresponding to a gage height of $17.86 \mathrm{ft}$ and a discharge of $72 \mathrm{ft}^{3} / \mathrm{s}$. The effect on the hydrograph at site $B$ is shown in figure 10.

One additional effect on the discharge at site B results when debris clogs the flared end section of the pipe passing beneath the FRS (fig. 11). The debris commonly collects on the pipe inlet as water ponded behind the FRS recedes after a storm. The degree to which the clogging is enhanced by the trash rack (fig. 11) is not known. The debris causes stages in the reservoir to be higher than normal for longer periods during subsequent storms. Associated with these higher stages are lower than normal discharges from the FRS, as water is released more slowly through the clogged pipe. Throughout the period of study, a local observer regularly removed the debris from the pipe inlet, and no major peaks were affected. However, without continual maintenance, duration time of water behind the FRS would be considerably longer.

There also is a slight attenuation of peak discharge between sites $C$ and $D$, due to a culvert beneath County Highway T (fig. 12), downstream from the gage at site $C$. This culvert ponds water and releases it slowly in a manner similar to that of the FRS. For example, during the storm of July 21, 1977, the peak discharge at site $C$ was $142 \mathrm{ft}^{3} / \mathrm{s}$, while at site $D$ it was $103 \mathrm{ft}^{3} / \mathrm{s}$ (fig. 13). This is a 28-percent reduction. During the storm of June 17, 1978, the peak discharge was reduced 19 percent from site C to site $D$.

\section{SEDIMENTATION PROCESSES}

Sediment transport in streams can be described in terms of sediment concentration (mass per unit volume, usually milligrams per liter), sediment load (mass, usually tons), sediment discharge (mass per unit time, usually tons per year), or sediment yield (sediment discharge per unit area, usually tons per year per square mile). The total amount of sediment transported can be divided into two general classes: suspended sediment and bedload. Suspended sediment is carried in suspension by turbulent currents. Bedload is that material moving on or near the streambed by rolling, sliding, and bounc- 


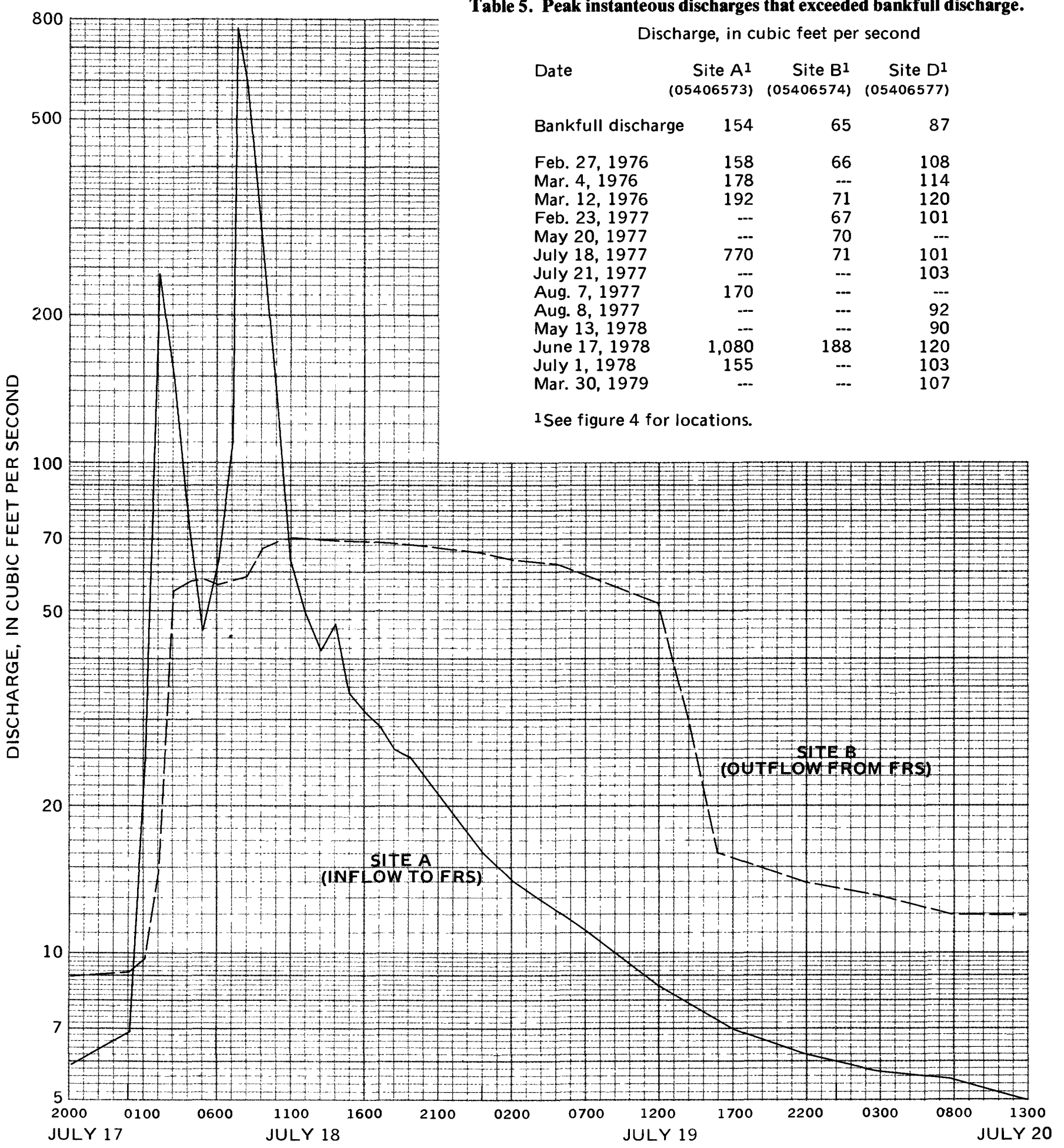

Figure 9. Hydrograph showing effect of the floodwater-retarding structure (FRS) on flood discharges, 1977. 


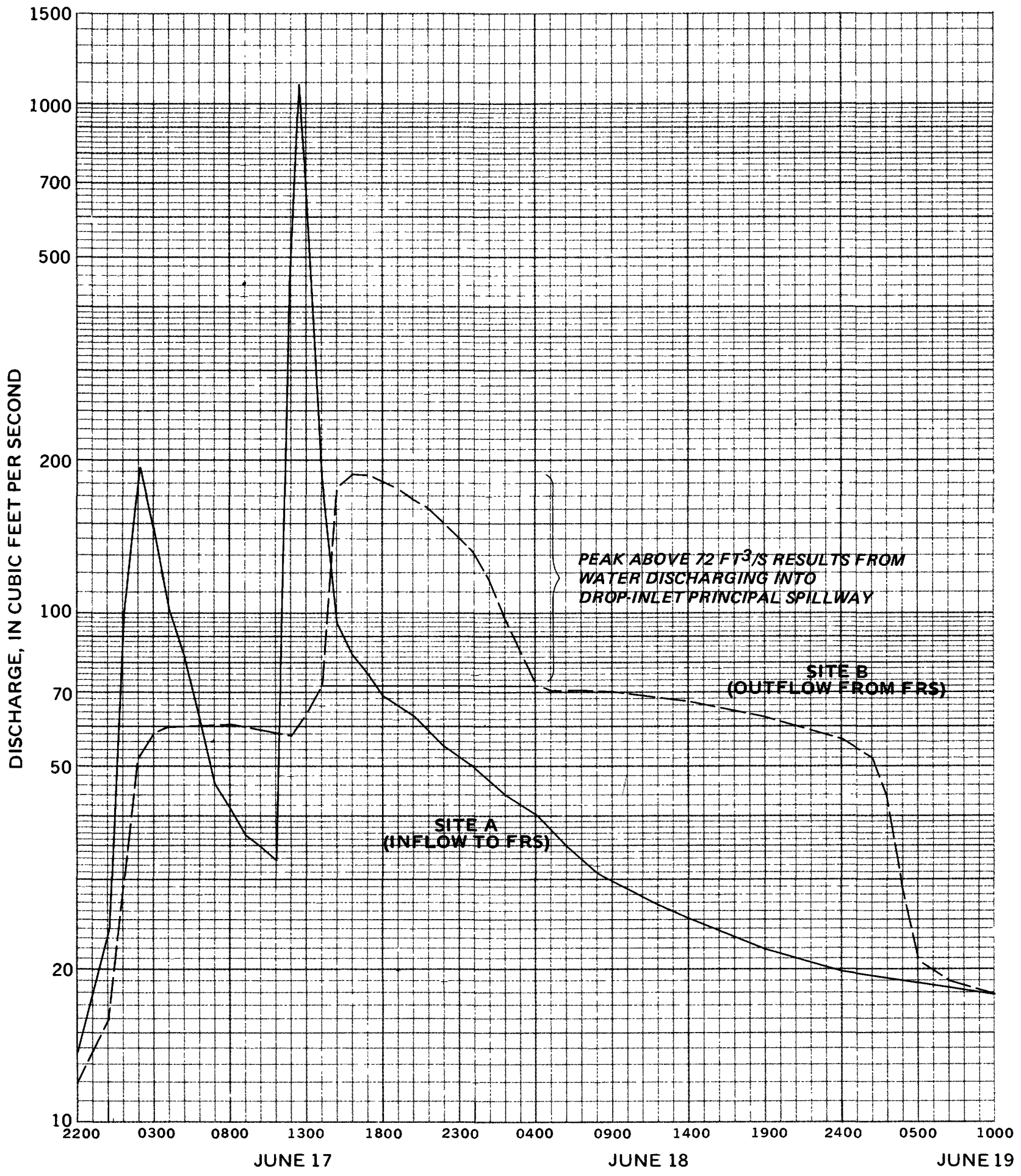

Figure 10. Hydrograph showing effect of the floodwater-retarding structure (FRS) on flood discharges, 1978. 
Table 6. Flood-frequency characteristics for gaging stations.

\begin{tabular}{cccc}
\hline & \multicolumn{3}{c}{ Instantaneous discharge $\left(\mathrm{ft}^{3 / \mathrm{s}}\right)$} \\
\cline { 2 - 4 } $\begin{array}{c}\text { Recurrence } \\
\text { interva1 } \\
\text { (years) }\end{array}$ & $\begin{array}{c}\text { Site } \mathrm{A}^{1} \\
(05406573)\end{array}$ & $\begin{array}{c}\text { Site } \mathrm{B}^{1} \\
(05406574)\end{array}$ & $\begin{array}{c}\text { Site } \mathrm{D}^{1} \\
(05406577)\end{array}$ \\
\hline 2 & 350 & 73 & 83 \\
5 & 1,010 & 122 & 129 \\
\hline
\end{tabular}

\section{${ }^{1}$ See figure 4 for locations.}

ing. Bed material, as distinguished from bedload, refers to the sediment mixture of which the bed is composed.

Suspended-sediment samples were collected at sites A, C, and D (fig. 4). At site B (fig. 4), bed material was remobilized as it traveled through the culvert, and total-sediment concentrations were measured by suspended-sediment sampling procedures at the culvert exit. The procedures are outlined by Guy and Norman (1970). A local observer collected sediment samples at sites A, B, and D from October 1975 to September 1979 and at site C from October 1975 to September 1978 with standard samplers at frequencies listed below:

$\begin{array}{cc}\text { Site } & \text { Sample frequency } \\ \text { A } & \text { Weekly } \\ \text { B } & \text { Every other day } \\ \text { C } & \text { Weekly } \\ \text { D } & \text { Every other day, 1976-78 } \\ & \text { weekly, 1979 }\end{array}$

At all sites, more frequent samples were collected during floods. To supplement the sediment samples collected by the local observer, automatic Isco model 1680 samplers were installed at sites A, B, and $D$ in October 1978. The samplers were activated by increases in stage and provided suspendedsediment samples throughout floods during the 1979 water year.

To compare the suspended-sediment concentrations measured at sites $A, C$, and $D$ with the total-sediment concentrations measured at site $\mathrm{B}$, it was necessary to determine bedload for sites A, C, and $D$. This was accomplished for high flows by the modified Einstein procedure (Colby and Hembree, 1955). In addition, concurrent sampling for suspended sediment at site $\mathrm{C}$ and for total sediment at a culvert exit about $300 \mathrm{ft}$ downstream provided supplemental data for estimating bedload at site C during low flow. Total-sediment concentrations at site $C$ were measured with the same procedures used at site B. Bedload, as a percentage of total sediment transported for sites A, C, and D during the study period, was estimated to be as follows:

Bedload

$\begin{array}{ccc}\text { Site } & \begin{array}{c}\text { (percent of total-sediment load) } \\ \text { Mean }\end{array} & \begin{array}{c}\text { Range } \\ \text { A }\end{array} \\ \text { C } & 0 & 0 \\ \text { D } & 6 & 0-29 \\ & 6 & 4-9\end{array}$

Sediment-discharge determinations normally are less accurate than streamflow measurements. Suspended-sediment discharge $\left(G_{s}\right)$ is computed from stream discharge $(Q)$ and suspended-sediment concentration (S):

$$
\mathrm{G}_{\mathrm{s}}=\mathrm{Q} \times \mathrm{S} \times \mathrm{F}
$$

where $F$ is a conversion factor to maintain consistent units. Streamflow records for the Trout Creek stations generally are classified as good: 95 percent of the daily-mean discharges are estimated to be within 10 percent of the true values. However, because analytical and sampling errors are associated with sediment concentrations, suspended-sediment discharges are expected to be less accurate than streamflows. Measured bedload discharges also are affected by analytical and sampling errors, and calculated bedload discharges may be in error by more than 100 percent (William W. Emmett, written commun., 1981). Because the calculated bedload discharges at sites A, C, and D are relatively small, the latter source of error is thought to be minor in this study. Sediment concentrations and particle-size distributions of the suspended sediment and bed material were determined by standard 


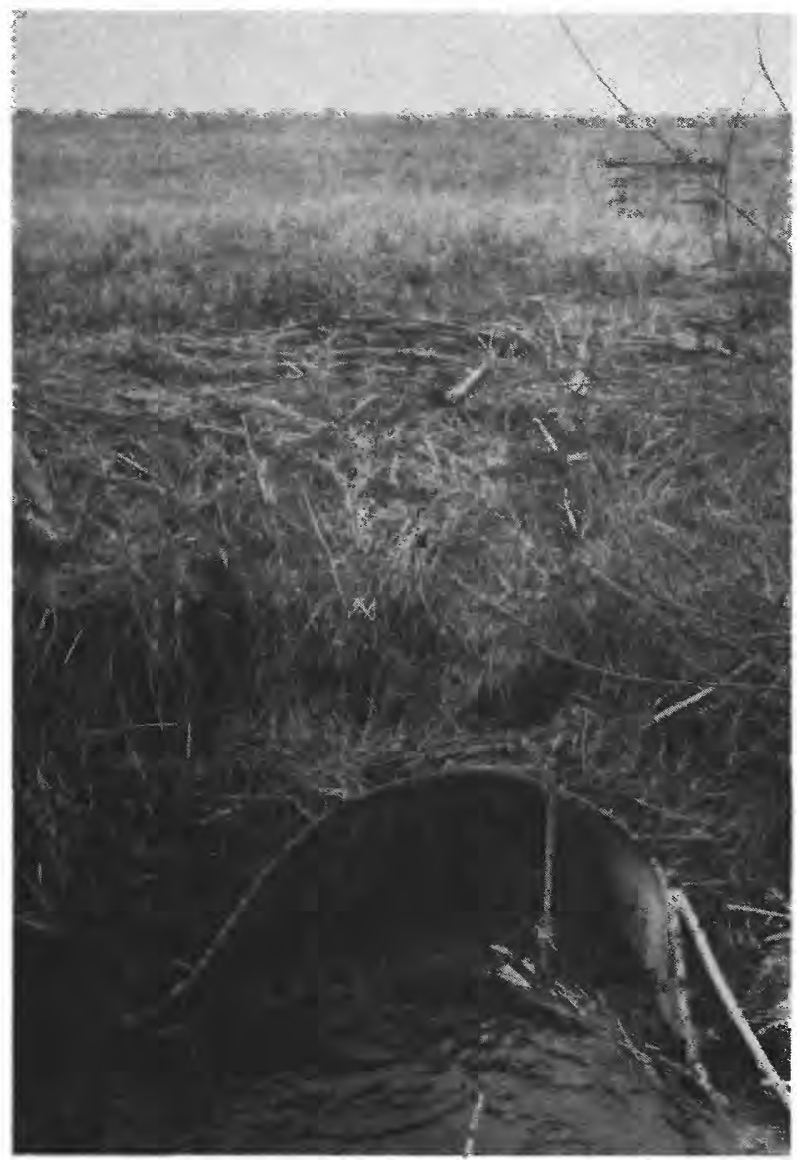

Figure 11. Looking downstream toward the floodwater-retarding structure (FRS). laboratory methods described by Guy (1969). Sediment-discharge data for the Trout Creek basin have been published separately (U.S. Geological Survey, 1978, 1979, 1980).

\section{Effects of the FRS on Sediment Transport}

The drainage area above site $\mathrm{A}$ is small, and sediment transport follows the behavior predicted by Colby (1963, p. 22-23), who notes: "If the distance of travel from the point of erosion is short or the stream channels contain little flow prior to the storm runoff, the peak concentration of fine material usually coincides with the peak flow or somewhat precedes it."

At site B, sediment transport is in direct opposition to the behavior at site $A$ : there is an inverse relationship between sediment concentration and streamflow. The data of March 11-17, 1976, (fig. 14) illustrate this behavior and the complexity of the sedimentation processes within the storage pool of the FRS. As water went into storage in the flood pool on March 11-13, the daily-mean total-sediment concentration in the FRS outflow dropped from 562 $\mathrm{mg} / \mathrm{L}$ (milligrams per liter) to $147 \mathrm{mg} / \mathrm{L}$. An analysis of the particle sizes of the sediment near the end of storage on March 13 indicates that only 3 percent of this outflow concentration was sand (nominal diameter $<0.062 \mathrm{~mm}$ ). Total-sediment concentrations in the outflow increased to $809 \mathrm{mg} / \mathrm{L}$ on March 14 as the discharge dropped; concentrations

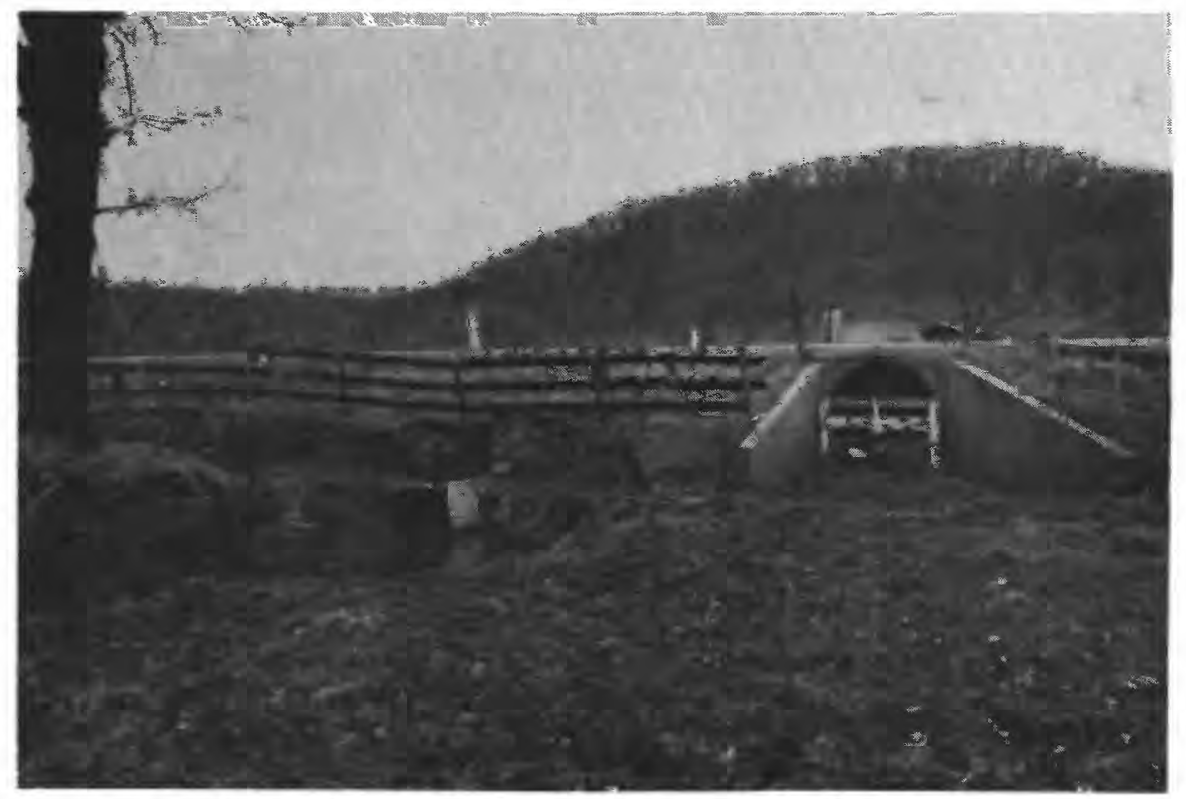

Figure 12. Looking downstream toward the culvert under County Highway $\mathbf{T}$, directly downstream from site $\mathbf{C}$. 


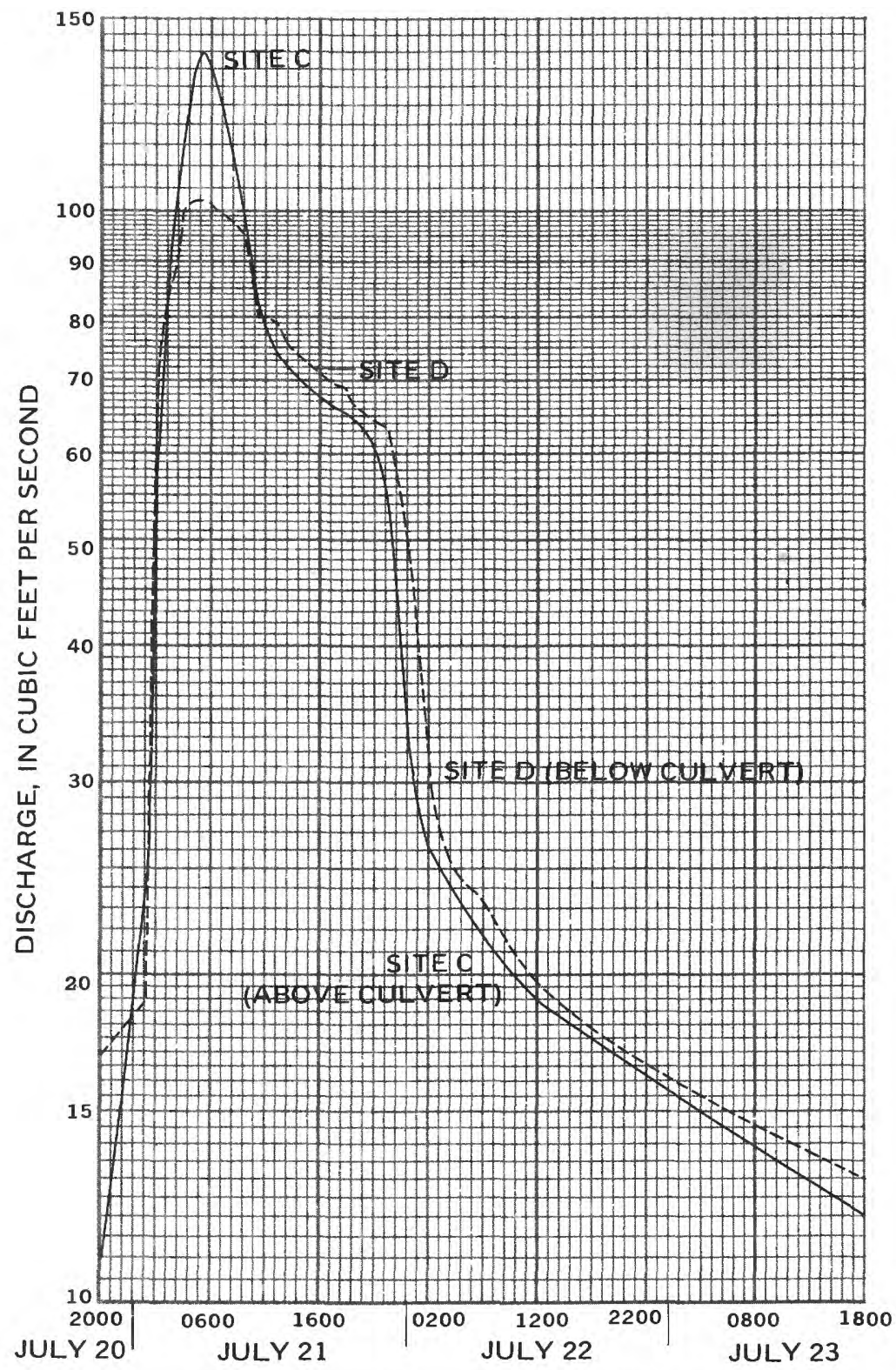

Figure 13. Hydrograph showing effect of the culvert under County Highway T on flood discharges, 1977.

remained above $400 \mathrm{mg} / \mathrm{L}$ for several weeks thereafter. Particle-size analyses of total-sediment samples taken after the detention period show that the sand fraction had increased to 56 percent on March 14 and to 79 percent on March 16 . In general, as water is stored behind the FRS during floods, sediment is trapped temporarily; this sediment, much of which is sand, is released slowly during relatively long periods following the discharge peak.

To explain the above behavior, the channel in the flood pool of the FRS first must be described.
The channel upstream from the FRS is deeply entrenched (fig. 15). The stage in the reservoir generally must rise more than $7 \mathrm{ft}$ before the water spills over the channel banks. On the other hand, ponding of the reservoir flood pool begins within the channel when the stream rises $1.2 \mathrm{ft}$ above normal stages.

When water begins ponding behind the FRS, the stream velocity decreases. Much of the sediment is deposited on the stream-channel bottom because ponding begins at stages several feet lower than the top of the channel. The heavier sand fraction is 


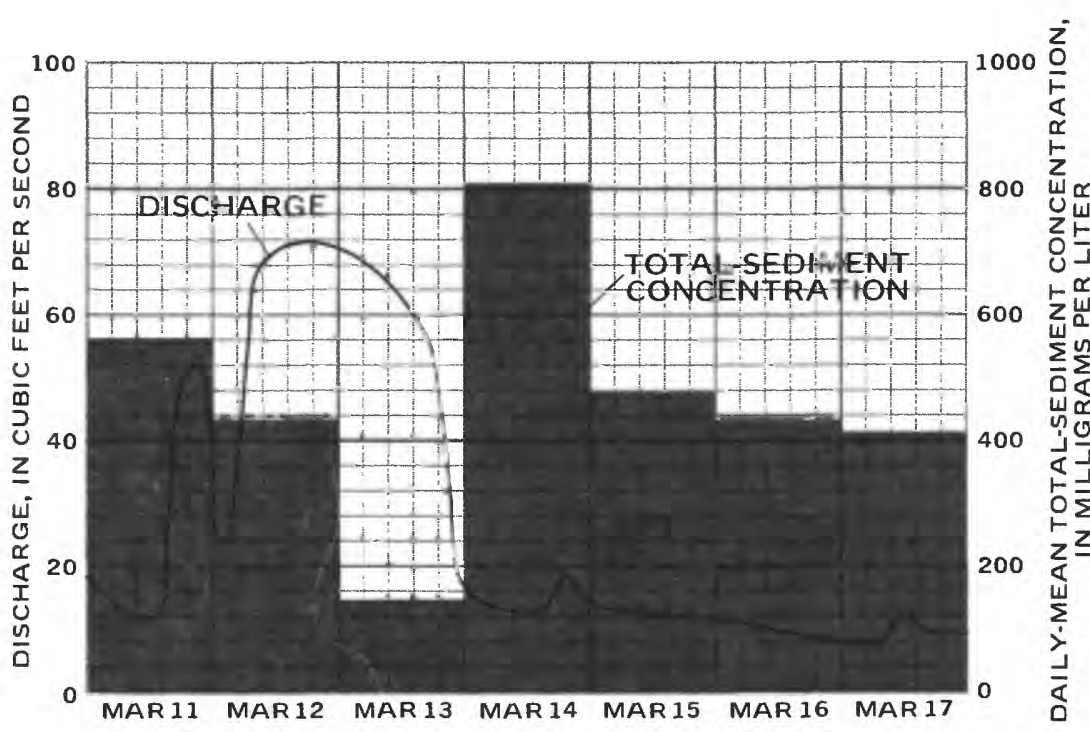

Figure 14. Hydrographs showing discharge and daily-mean-total-sediment concentrations in the outflow from the floodwater-retarding structure (FRS), 1976.

deposited first, leaving relatively greater amounts of silt and clay in suspension. When the water in the storage pool drains sufficiently so that the water is no longer ponded, stream velocities increase (even though discharge has decreased), and the sediment on the channel bottom is remobilized and carried from the reservoir.

A large percentage of the sediment transported from the FRS (site B) is sand, much of which is transported as bedload. The bedload at site B was determined by collecting suspended-sediment samples at the upstream end (flared end- section inlet) of the principal spillway pipe and by collecting total-sediment samples at the downstream end of the pipe (the normal collection site). The difference between sediment loads at the two sites represents the bedload fraction; it ranged from 12 to 92 percent of the total-sediment load for streamflows of 7.4 to $15 \mathrm{ft}^{3} / \mathrm{s}$. This is much higher than the bedload determined at the other sites.

To indicate the prolonged period of sediment release from the reservoir, the cumulative totalsediment loads at sites A and B are shown in figure 16. This figure shows that most of the sediment that passes site A during floodflows is released from the reservoir at a later time. The period from June 1978 to September 1979 shows the prolonged release of sediment from the reservoir during the study. The storm on June 17, 1978, was the largest during the study period and transported about 1,640 tons of sediment past site A in a 3-day period. As only 428 tons of sediment passed site $B$ during the same period, most of the sediment was deposited in the channel of the reservoir flood pool. This sediment still was being released at the end of data-collection in September 1979. Figure 17 illustrates the resulting higher total-sediment concentrations at site B than at site A during the entire 1979 water year.

Finally, there are indications that clogging of the pipe beneath the FRS has considerable effect on sediment transport. In early 1975 , sediment depths in the channel just upstream from the FRS were 1.5 $\mathrm{ft}$ or greater (see W. L. Hilsenhoff, "Arthropod Fauna"). Removal of the debris from the pipe inlet at the beginning of the study allowed this sediment to erode. Continued maintenance throughout the study period prevented a recurrence of the large sediment accumulations in the channel upstream from the FRS and precluded documenting the mechanism that caused it. However, it seems reasonable to expect higher stages and lower velocities for longer periods upstream from a debris-clogged spillway. This would allow greater opportunity for sediment deposition and provide less chance for sediment remobilization as the stage behind the FRS dropped.

\section{Sediment-Trapping Efficiency of the FRS}

Sediment-trapping efficiency of a reservoir is the ratio of sediment deposited in the reservoir to the total amount of sediment entering the reservoir. To estimate the trap efficiency of the FRS on Trout Creek, the measured sediment load at site A during the period of study (sum of annual values, table 7) was adjusted for the intervening drainage area $(0.65$ $\mathrm{mi}^{2}$ ) between sites A and $\mathrm{B}$. The measured sediment load at site B during the study (sum of annual values, table 7) was subtracted from this value, and 

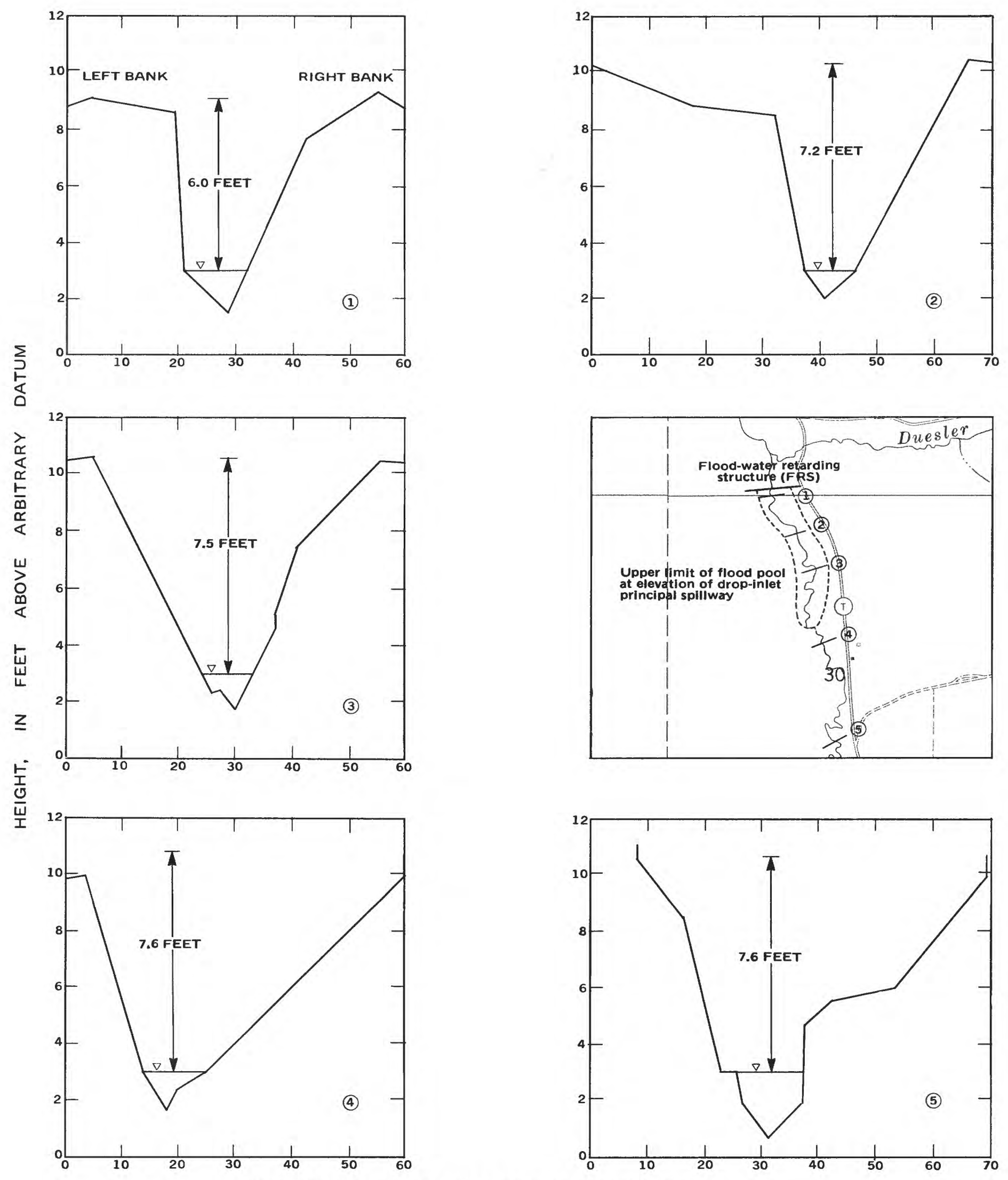

DISTANCE FROM LEFT END OF CROSS SECTION, IN FEET

Figure 15. Shapes of channel cross sections upstream

from the floodwater-retarding structure (FRS), 1980. 
it was determined that a maximum of 416 tons of sediment was trapped behind the FRS during water years 1976-79. This translates to a trap efficiency of about 7 percent.

On a short-term basis, the calculated trap efficiency of the FRS is likely to be highly variable because sediment discharges at site $\mathrm{B}$ for a given water year may reflect sediment that was deposited in the stream channel above the FRS during the previous water year. Comparison of monthly and annual total-sediment loads (table 7) at site $A$ with those at site B provides some interesting results in this regard. For example, during the 1979 water year, the annual total-sediment load at site $A$ above the FRS was 374 tons, while the sediment load exiting from the reservoir was 1,330 tons. This represents a net contribution from the reservoir of somewhat less than 956 tons, after adjusting for the drainage area between sites A and B. Conversely,

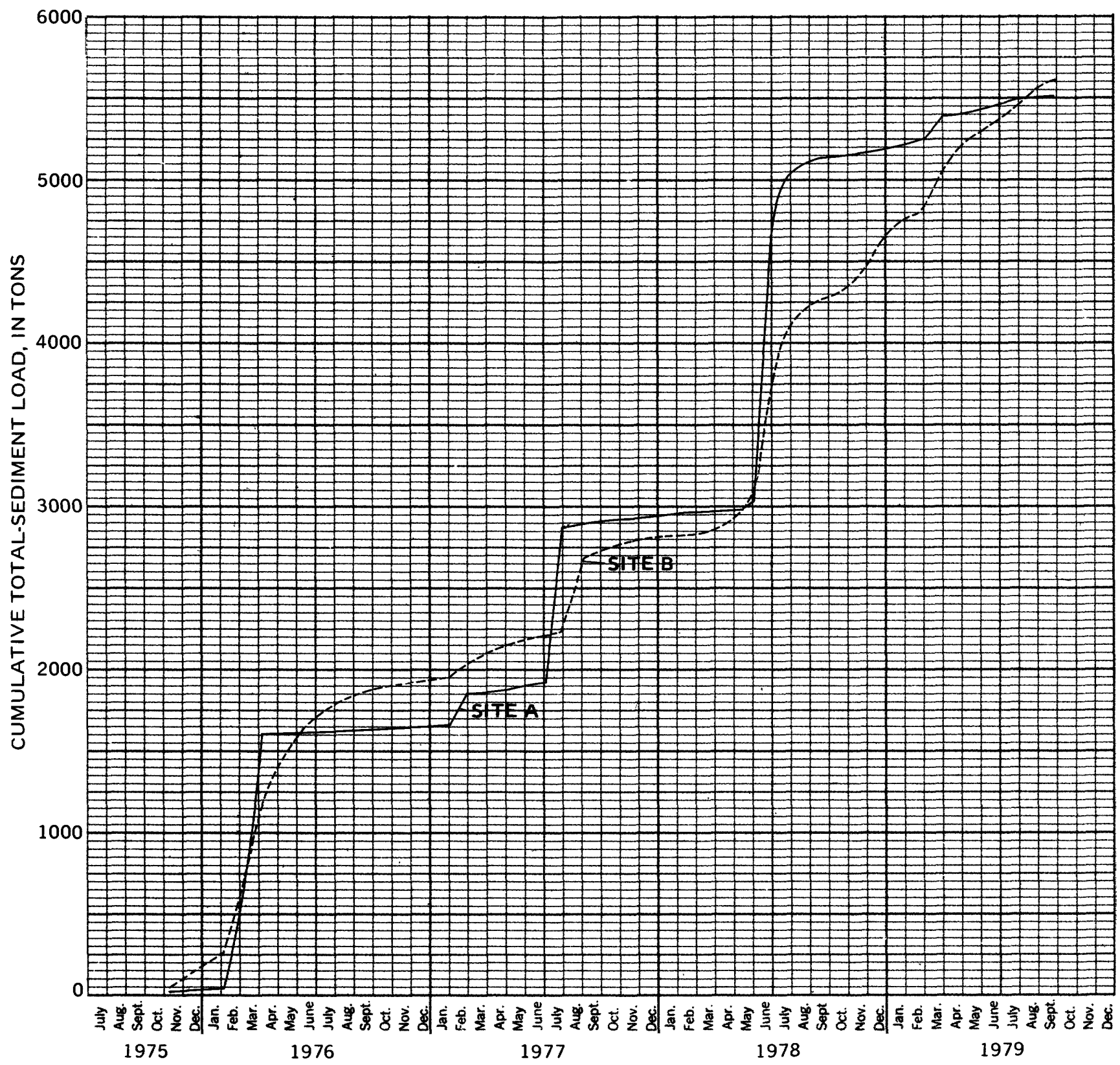

Figure 16. Cumulative total-sediment loads, 1976-79 water years. 
Table 7. Monthly and annual total-sediment loads, in tons.

\begin{tabular}{|c|c|c|c|c|c|c|c|c|c|c|c|c|c|}
\hline Site & oct. & Nov. & Dec. & Jan. & Feb. & Mar. & Apr. & May & June & July & Aug. & Sept. & Annual \\
\hline \multicolumn{14}{|c|}{1976 Water Year } \\
\hline $\begin{array}{l}\text { A } \\
\text { B } \\
\text { C } \\
\text { D }\end{array}$ & $\begin{array}{l}13.3 \\
53.6 \\
72.1 \\
76.6\end{array}$ & $\begin{array}{l}11.9 \\
54.2 \\
95.1 \\
74.2\end{array}$ & $\begin{array}{l}13.4 \\
72.6 \\
64.0 \\
75.3\end{array}$ & $\begin{array}{l}10.2 \\
72.0 \\
41.9 \\
57.0\end{array}$ & $\begin{array}{l}474 \\
323 \\
526 \\
530\end{array}$ & $\begin{array}{r}1,090 \\
656 \\
788 \\
846\end{array}$ & $\begin{array}{l}8.55 \\
206 \\
136 \\
136\end{array}$ & $\begin{array}{c}9.66 \\
199 \\
67.3 \\
60.5\end{array}$ & $\begin{array}{c}7.15 \\
106 \\
47.2 \\
44.2\end{array}$ & $\begin{array}{l}3.27 \\
74.7 \\
26.8 \\
29.7\end{array}$ & $\begin{array}{l}1.62 \\
63.3 \\
10.8 \\
15.1\end{array}$ & $\begin{array}{l}2.31 \\
19.4 \\
15.5 \\
16.1\end{array}$ & $\begin{array}{l}1,650 \\
1,900 \\
1,890 \\
1,960\end{array}$ \\
\hline \multicolumn{14}{|c|}{1977 Water Year } \\
\hline $\begin{array}{l}\text { A } \\
\text { B } \\
\text { C } \\
\text { D }\end{array}$ & $\begin{array}{l}5.27 \\
21.0 \\
23.3 \\
10.7\end{array}$ & $\begin{array}{l}2.55 \\
21.4 \\
22.6 \\
14.5\end{array}$ & $\begin{array}{l}3.10 \\
18.5 \\
12.0 \\
11.7\end{array}$ & $\begin{array}{c}2.75 \\
11.4 \\
10.4 \\
9.88\end{array}$ & $\begin{array}{l}212 \\
103 \\
167 \\
223\end{array}$ & $\begin{array}{l}13.2 \\
53.3 \\
48.7 \\
47.2\end{array}$ & $\begin{array}{l}2.80 \\
31.0 \\
24.4 \\
25.4\end{array}$ & $\begin{array}{l}19.8 \\
49.5 \\
72.3 \\
75.6\end{array}$ & $\begin{array}{c}2.93 \\
16.3 \\
14.5 \\
8.43\end{array}$ & $\begin{array}{l}963 \\
293 \\
315 \\
299\end{array}$ & $\begin{array}{c}439 \\
154 \\
128 \\
37.6\end{array}$ & $\begin{array}{l}9.06 \\
66.1 \\
53.6 \\
16.7\end{array}$ & $\begin{array}{r}1,280 \\
839 \\
892 \\
780\end{array}$ \\
\hline \multicolumn{14}{|c|}{1978 Water Year } \\
\hline $\begin{array}{l}\text { A } \\
\text { B } \\
\text { C } \\
\text { D }\end{array}$ & $\begin{array}{l}6.23 \\
35.1 \\
22.2 \\
12.3\end{array}$ & $\begin{array}{c}5.39 \\
24.4 \\
15.9 \\
18.9\end{array}$ & $\begin{array}{l}9.82 \\
17.8 \\
33.8 \\
21.5\end{array}$ & $\begin{array}{c}3.89 \\
19.6 \\
5.82 \\
33.6\end{array}$ & $\begin{array}{c}3.60 \\
6.90 \\
8.38 \\
19.4\end{array}$ & $\begin{array}{l}5.80 \\
25.5 \\
18.7 \\
43.2\end{array}$ & $\begin{array}{c}10.2 \\
66.3 \\
73.3 \\
108\end{array}$ & $\begin{array}{l}54.8 \\
139 \\
190 \\
294\end{array}$ & $\begin{array}{r}1,730 \\
743 \\
1,220 \\
984\end{array}$ & $\begin{array}{l}315 \\
329 \\
635 \\
559\end{array}$ & $\begin{array}{c}47.2 \\
85.1 \\
114 \\
75.9\end{array}$ & $\begin{array}{c}33.9 \\
64.3 \\
104 \\
83.8\end{array}$ & $\begin{array}{l}2,220 \\
1,560 \\
2,440 \\
2,250\end{array}$ \\
\hline \multicolumn{14}{|c|}{1979 Water Year } \\
\hline $\begin{array}{l}\text { A } \\
\text { B }\end{array}$ & $\begin{array}{l}14.6 \\
43.7\end{array}$ & $\begin{array}{l}21.6 \\
146\end{array}$ & 201.8 & $\begin{array}{l}27.3 \\
91.8\end{array}$ & $\begin{array}{l}25.5 \\
35.6\end{array}$ & $\begin{array}{l}139 \\
293\end{array}$ & $\begin{array}{l}21.7 \\
96.2\end{array}$ & 21.4 & $\begin{array}{l}26.3 \\
85.8\end{array}$ & $\begin{array}{l}24.0 \\
62.2\end{array}$ & $\begin{array}{l}21.5 \\
120\end{array}$ & $\begin{array}{c}8.94 \\
50.4\end{array}$ & $\begin{array}{r}373 \\
1,330\end{array}$ \\
\hline $\mathrm{C}$ & -- & - & -- & -- & - & - & -- & - & - & - & - & -- & -- \\
\hline D & 86.1 & 98.3 & 109 & 103 & 45.6 & 676 & 190 & 192 & 65.2 & 35.2 & 97.7 & 67.2 & 1,770 \\
\hline
\end{tabular}

\footnotetext{
${ }^{1}$ See figure 4 for locations.
} 


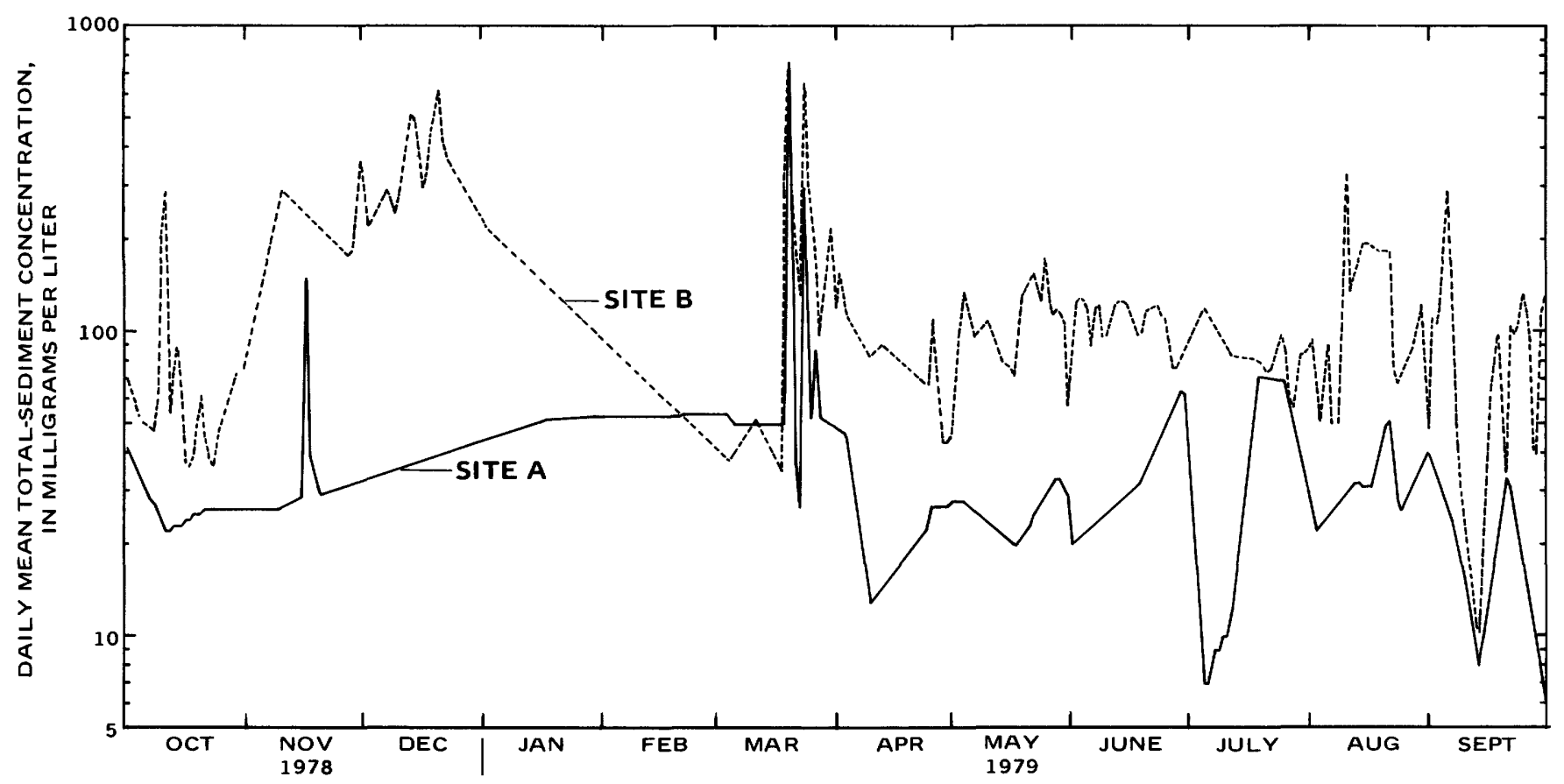

Figure 17. Daily-mean total-sediment concentrations, 1979 water year.

during the 1978 water year, there was a net trapping of at least 670 tons of sediment behind the FRS. This occurred because of the large quantity of sediment deposited in June 1978, the only month when the total-sediment load leaving the reservoir was less than the sediment load at site A (table 7). A longer period of record would be required to estimate adequately the true trap efficiency of the FRS; however, the 4-year average trap efficiency of 7 percent is close to the range of 10 to 40 percent suggested by Brune (1953).

Brune (1953) notes that trap efficiencies for truly "dry" reservoirs, such as those in the Miami Conservancy District near Dayton, Ohio, probably range from 10 to 40 percent, depending on the capacity-inflow ratio. Curtis (1965), in a study of two dry reservoirs in the Miami Conservancy District, found trap efficiencies of 33 and 34 percent and felt it would be more appropriate to correlate detention or duration time of water in the reservoir to trap efficiency. This study has provided evidence that the deeply entrenched channel upstream from the FRS on Trout Creek is of considerable importance in determining sedimentation in the floodstorage pool and, thus, in controlling the trap efficiency of the FRS. Capacity-inflow ratio and detention time have not been investigated.

\section{Sediment Transport Downstream from the FRS}

The sediment-load data in table 7 indicate that some of the sediment passing site B is deposited in the channel downstream. Further indications that sediment is deposited downstream of site B is suggested from particle-size analyses of the bed material. The median particle sizes of bed-material samples collected at crossovers between meanders are shown in figure 18.

The median particle size averages $14 \mathrm{~mm}$ (medium gravel) above Birch Lake; from below the dam at Birch Lake to above the flood pool of the FRS the average is $9 \mathrm{~mm}$ (medium gravel); and below the FRS the average is $1 \mathrm{~mm}$ (coarse to very coarse sand). The large variability of the median particle sizes above the FRS (fig. 18) makes average values difficult to interpret; however, the variability disappears below the FRS, and it is obvious that the particle size of the bed material downstream from the FRS is less than that upstream.

Below large-capacity reservoirs having high trap efficiencies, Komura and Simmons (1967) found that the riverbed degrades due to the arrest of 


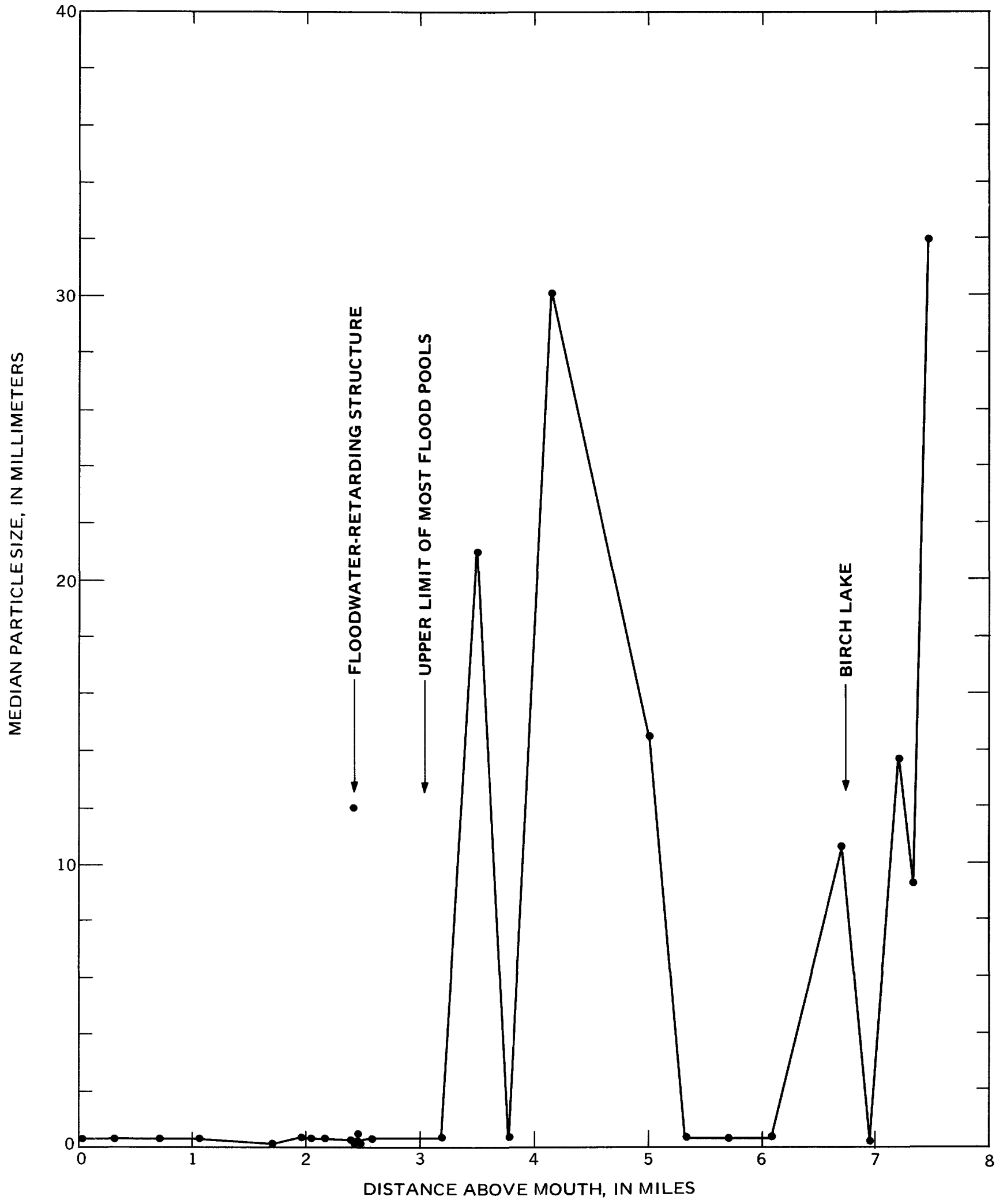

Figure 18. Median particle size of bed material, December 1977.

sediment transport by the reservoir, and that there is an increase in the median size of the bed material. The increase was attributed to the clear water being released by the dam and the subsequent removal of the finer fraction of bed material from the streambed. Consequently, the streambed below the dam became armored with coarser bed material.
The principle of increased sediment transport should apply downstream from any structure providing high sediment trapping efficiency and clearwater releases. The bed material downstream from site $B$ is not indicative of release of clear water from the reservoir. Instead, the coarser materials apparently have been covered by finer materials that are 
transported from the reservoir during low-water periods and that are not readily eroded during floods because of reduced peak discharges below the FRS.

\section{Sediment Yields}

With the exception of site $B$, which is complicated by effects of the FRS, sediment yields in the Trout Creek basin were highest during the 1978 water year (table 8). Sediment yields generally decreased downstream (table 8), as expected from a downstream decrease in sediment-delivery ratio (Gottschalk, 1964). The range of mean annual sediment yields is relatively small, from 200 tons/ $\mathrm{mi}^{2}$ at site $\mathrm{A}$ to 140 tons $/ \mathrm{mi}^{2}$ at site $\mathrm{D}$.

By way of comparison, in 1975 the sediments deposited in Birch Lake (fig. 4) were surveyed by Cheetham and Wilke (1976). They found the mean annual sediment yield for a 10-year period to be 986 tons $/ \mathrm{mi}^{2}$. This measured sediment yield at Birch Lake was almost double the annual yield of 454 tons $/ \mathrm{mi}^{2}$ that had been predicted for the reservoir (Cheetham and Wilke, 1976). The higher actual yield was attributed to (1) more than average yearly precipitation for several years, (2) high erosion rates from excavated areas within the drainage basin of the reservoir, (3) almost annual replenishment of beach and swimming area sand on the lakeshore (35 tons annually), and (4) greater percentages of sand in the eroded material than had been anticipated (sand has a higher trapping rate). The measured yield above Birch Lake also is considerably greater than might have been expected from the data in table 8. Thus, sediment erosion above Birch Lake apparently is greater, by a factor of 5 to 7 , than in the basin downstream from the lake.

\section{CHANNEL MORPHOLOGY}

Channel morphology refers to the shape and form of stream channels as controlled by stream discharges. In this study, cross-sectional area (A), surface width $(w)$, mean depth $(\bar{d}=A / w)$, and bankfull discharge $\left(Q_{B}\right)$ were investigated at eight reaches near the gages on Trout Creek (fig.19). The number of cross sections established in each reach ranged from 3 at reach 6 to 10 at reaches 2 and 4 (table 10). Cross sections were permanently monumented by driving steel rods into the ground and surveying them in relation to permanent reference marks. The reaches were surveyed in 1975, 1977, and 1979.

\section{Bankfull Discharge}

Bankfull discharge is the discharge that just begins to overflow the active flood plain (Emmett, 1975; Wolman and Leopold, 1957); it is considered to be the dominant discharge that creates and shapes the stream channel (Emmett, 1975). The bankfull discharge has an approximate recurrence interval of 1.5 to 2.0 years (Wolman and Leopold, 1957).

Table 8. Sediment yields.

(Sediment yield, in tons/mi2) ${ }^{1}$

\begin{tabular}{|c|c|c|c|c|}
\hline Water year & Site $A^{2}$ & Site $B^{2}$ & Site $c^{2}$ & Site $D^{2}$ \\
\hline $\begin{array}{l}1976 \\
1977 \\
1978 \\
1979\end{array}$ & $\begin{array}{r}238 \\
185 \\
322 \\
54.1\end{array}$ & $\begin{array}{l}252 \\
111 \\
206 \\
177\end{array}$ & $\begin{array}{c}178 \\
83.9 \\
229 \\
--\end{array}$ & $\begin{array}{c}163 \\
64.8 \\
187 \\
147\end{array}$ \\
\hline Mean & 200 & 186 & 164 & 140 \\
\hline
\end{tabular}




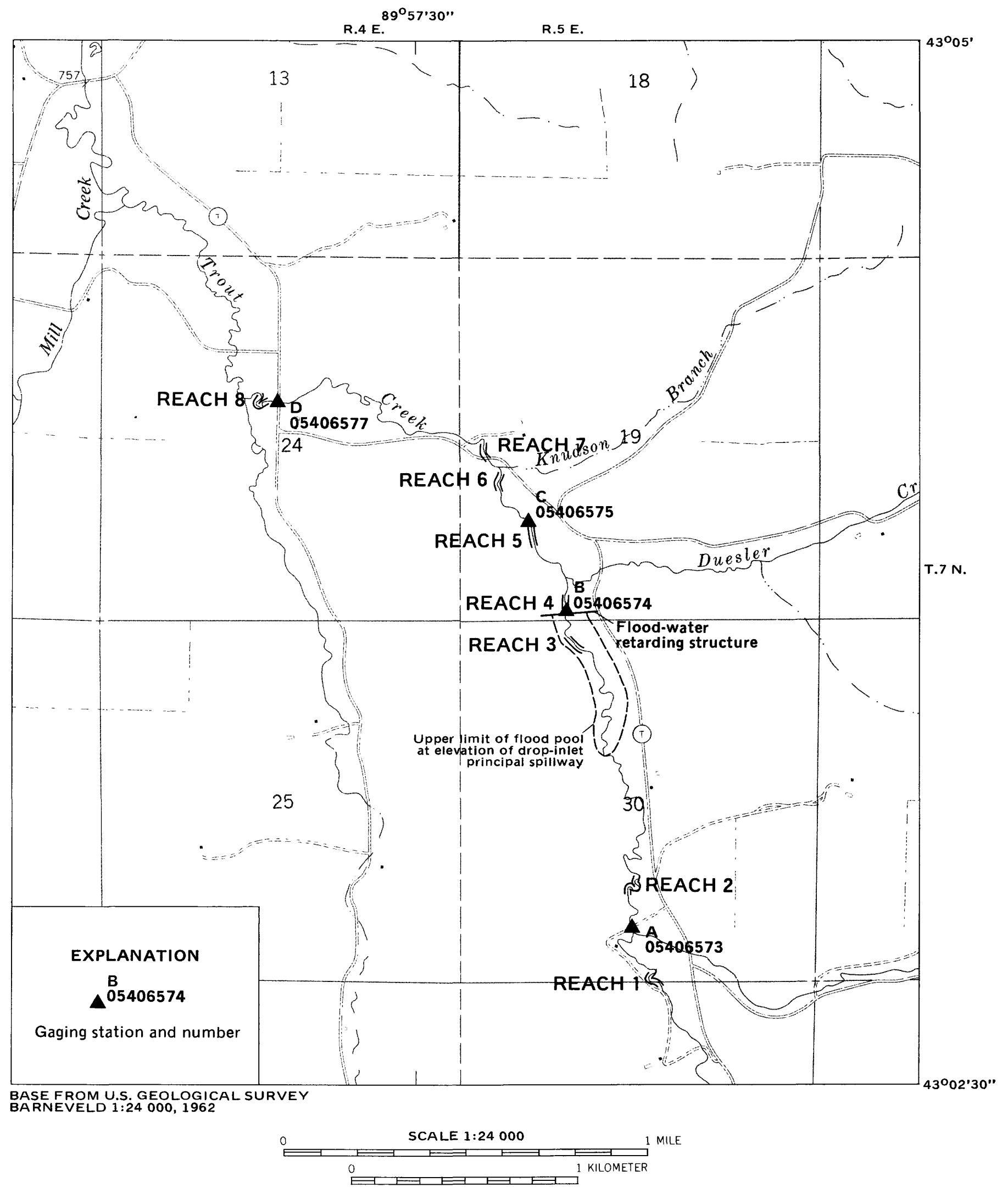

Figure 19. Locations of channel-morphology reaches. 
Three methods--rating-curve, Manning's equation, and Emmett's (1975) regression equation-were used to estimate the bankfull discharge. The rating- curve method used surveyed cross sections near gaging stations; it provided estimates of bankfull discharge at reaches $2,5,6$, and 8 (fig. 19). Longitudinal profiles of the thalweg, water-surface, and flood-plain elevations were plotted, and three parallel lines were drawn through the points (Emmett, 1975). Flood-plain elevations were defined as the elevations where the width-depth ratio $(w / \bar{d})$ reached a minimum (Williams, 1978), as determination of the flood-plain elevations by inspection of cross sections was too subjective and provided inconsistent estimates of bankfull stage. The difference between the flood-plain elevation and that of the water surface was calculated, and this value was added to the mean gage height for the day of the survey to provide an estimate of the bankfull stage at the gage. The stage-discharge relationship at the gage then was used to find the corresponding bankfull discharge.

Another method used to estimate bankfull discharge involves the use of Manning's equation,

where:

$$
Q=(1.486 / n) A S^{1 / 2} R^{2 / 3}
$$

$$
\begin{aligned}
& \mathbf{Q}=\text { discharge, in cubic feet per second, } \\
& \mathbf{n}=\text { roughness coefficient (dimensionless), } \\
& \mathbf{A}=\text { area of channel cross section, } \\
& \text { in square feet, } \\
& \mathbf{S}=\text { water-surface slope (dimensionless), and } \\
& \mathbf{R}=\text { hydraulic radius, in feet. }
\end{aligned}
$$

If the cross-sectional area and hydraulic radius at the elevation where the $w / \bar{d}$ ratio reaches a minimum are substituted into equation 2 , then an estimate of the bankfull discharge is obtained (Dalrymple and Benson, 1967). This procedure was used to estimate bankfull discharge at all reaches and at the 27 additional sites described under "Hydraulic Geometry". Estimates of $n$ in equation 2 were determined by field inspection of cross sections; values of $S$ were measured in the field and can be found in table 9. As several cross sections comprised a reach, the discharges at all cross sections within the reach were averaged, and a mean bankfull discharge for the reach was obtained.

Finally, bankfull discharge was estimated by a regression equation presented by Emmett (1975),

where:

$$
\mathrm{Q}_{\mathrm{B}}=28.3(\mathrm{DA})^{0.69} \text {, }
$$

$\mathrm{Q}_{\mathrm{B}}=$ bankfull discharge, in cubic feet per second, and

DA $=$ drainage area, in square miles.

Equation 3 was determined from data collected in the Upper Salmon River basin in south-central Idaho. This area lies in the northern Rocky Mountains and has a different physiography, topography, and climate than southwest Wisconsin. Direct applicability of equation 3 to the Trout Creek basin should not be expected; however, Emmett's (1975) equation provided some useful figures for comparison to the other methods used to estimate bankfull discharge.

The bankfull discharges for the Trout Creek basin reaches are summarized in table 9. Bankfull discharges at sites B and D compare favorably with the 2-year floods, as computed by the log-Pearson Type III technique (table 6). However, the bankfull discharge at site $A$ is only about one-third of the estimated 2-year flood. This discrepancy is attributed primarily to the variability of the data resulting from the short period of record.

Table 9 shows that the bankfull discharges calculated from Manning's equation and Emmett's (1975) regression equation increase from reach 1 to reach 2 near site $A$ and that the two techniques provide reasonably consistent results. Because Emmett's (1975) equation is a function of drainage area only, this method predicts that the discharge will continue to increase downstream. Manning's equation, on the other hand, shows a decrease in bankfull discharge, to a value of $65 \mathrm{ft}^{3} / \mathrm{s}$ at reach 4 just downstream from the FRS (table 9). Discharges of 58 to $71 \mathrm{ft}^{3} / \mathrm{s}$ are the normal outflow from the dam during storms. Because these values bracket the estimated bankfull discharge for reach 4 , this provides evidence that the stream channel is adjusting its size to a new bankfull discharge controlled by the reduced outflow from the FRS.

In the absence of the FRS, the bankfull discharge at reach 4 would be expected to be greater than at reach 2 because of the increased drainage area. Thus, one effect of the FRS is to reduce the bankfull capacity of the channel to less than half the expected value based on the drainage area. The bankfull discharge calculated by Emmett's (1975) equation increases by a factor of 1.32 from reach 4 to reach 8 . The bankfull discharge calculated by Manning's equation increases by a factor of 1.34 , showing good correspondence of bankfull discharge with drainage area below the FRS. The bankfull discharges at reaches 5 and 6 (table 9) seem to be low and may have been affected by backwater from the culvert at site $C$.

\section{Channel Geometry}

The channel geometry considered in this study includes cross-sectional area, width, average depth, and the $w / \bar{d}$ ratio, all at the elevation of the bankfull discharge. These properties were determined for each cross section. Mean values and standard 
Table 9. Bankfull discharges.

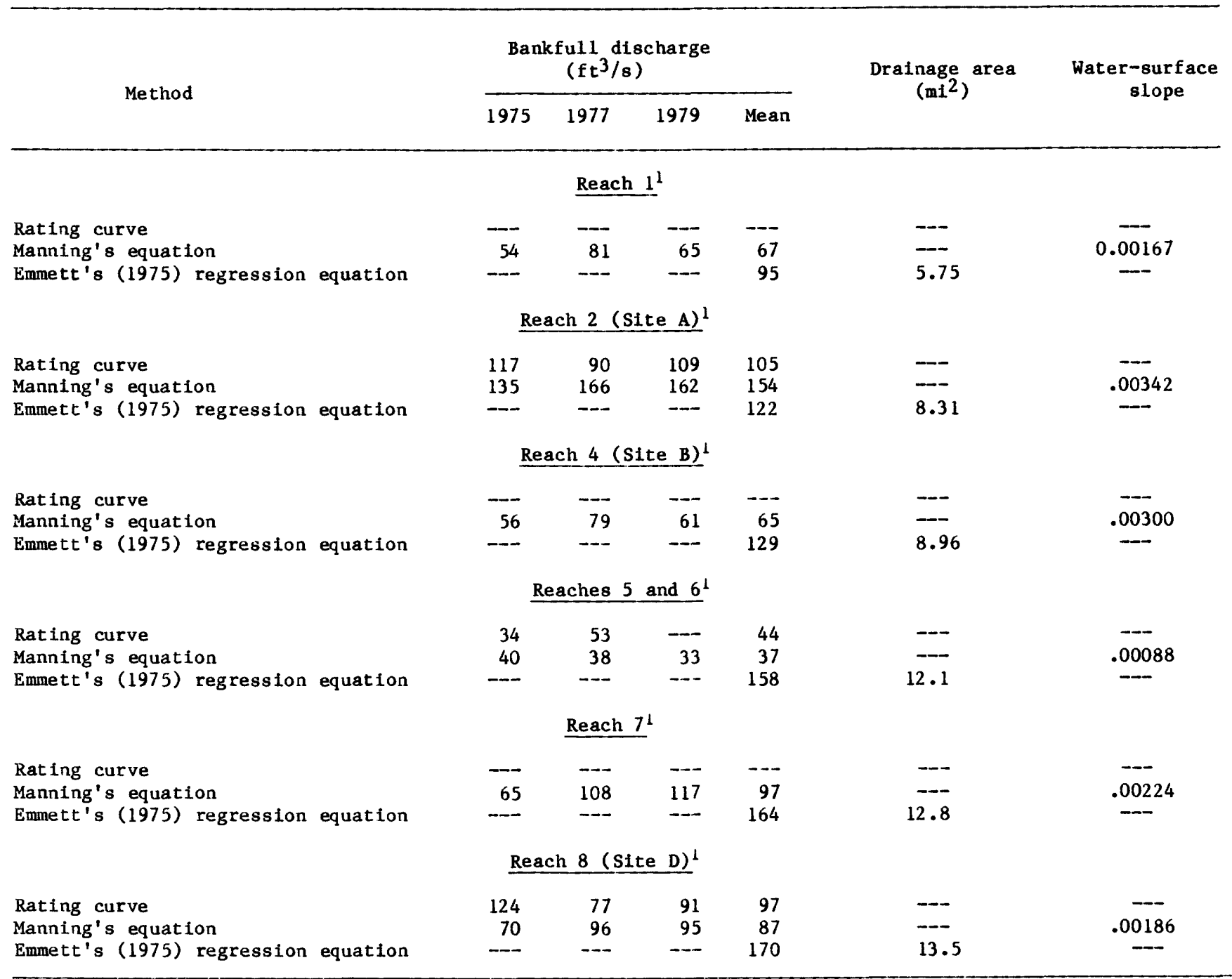

${ }^{1}$ See figure 19 for locations.

deviations for each reach and year are shown in table 10. Channel geometry is not reported for reach 3 , upstream from the FRS in the flood pool, because bankfull discharge could not be determined. Representative cross sections from reaches $1,2,4$, 5,7 , and 8--indicating changes in channel shape and size during the study, are shown in figure 20. As shown in table 10 and figure 20 , the channel geometry of the reaches changed little throughout the study.

Reaches 1 and 2 are upstream from the maximum limit of the flood pool behind the FRS during the study and are, respectively, upstream and downstream from site A (fig. 19). These reaches were used for control to determine effects on the reaches downstream from the FRS. Reaches 4 through 8 downstream from the FRS were used to determine effects of the FRS on channel geometry.

As noted previously, the most important effect of the FRS on channel morphology is reduction of bankfull discharge. However, because bankfull discharge controls the shape of the channel, the FRS also affects channel geometry. For example, mean cross-sectional area decreased 36 percent from reach 2 above the FRS to reach 4 downstream from the FRS (table 10). Other measuresures of channel geometry also reflect the effect of the FRS. Mean width at reach 2, upstream from the FRS, was 18.4 $\mathrm{ft}$, and mean depth was $2.2 \mathrm{ft}$. Downstream from the FRS at reach 4, mean width and mean depth were $21.7 \mathrm{ft}$ and $1.2 \mathrm{ft}$, respectively. The w/ $/ \overline{\mathrm{d}}$ ratio more than doubled from reach 2 to reach 4 . Thus, 

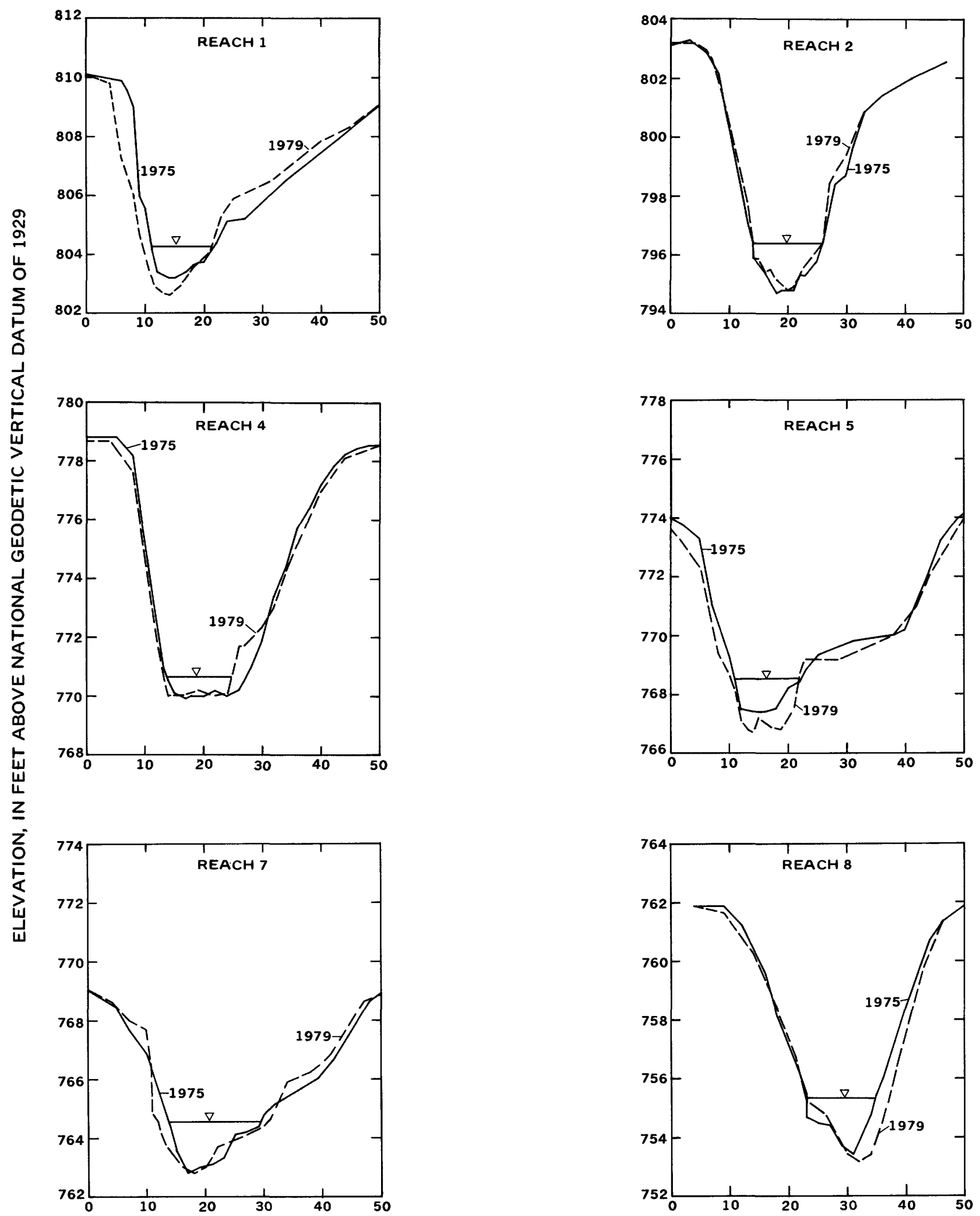

DISTANCE FROM LEFT END OF CROSS SECTION, IN FEET

Figure 20. Representative cross sections from the channel-morphology reaches. 
Table 10. Mean channel geometry, 1975-79.

(Standard deviation shown in parentheses)

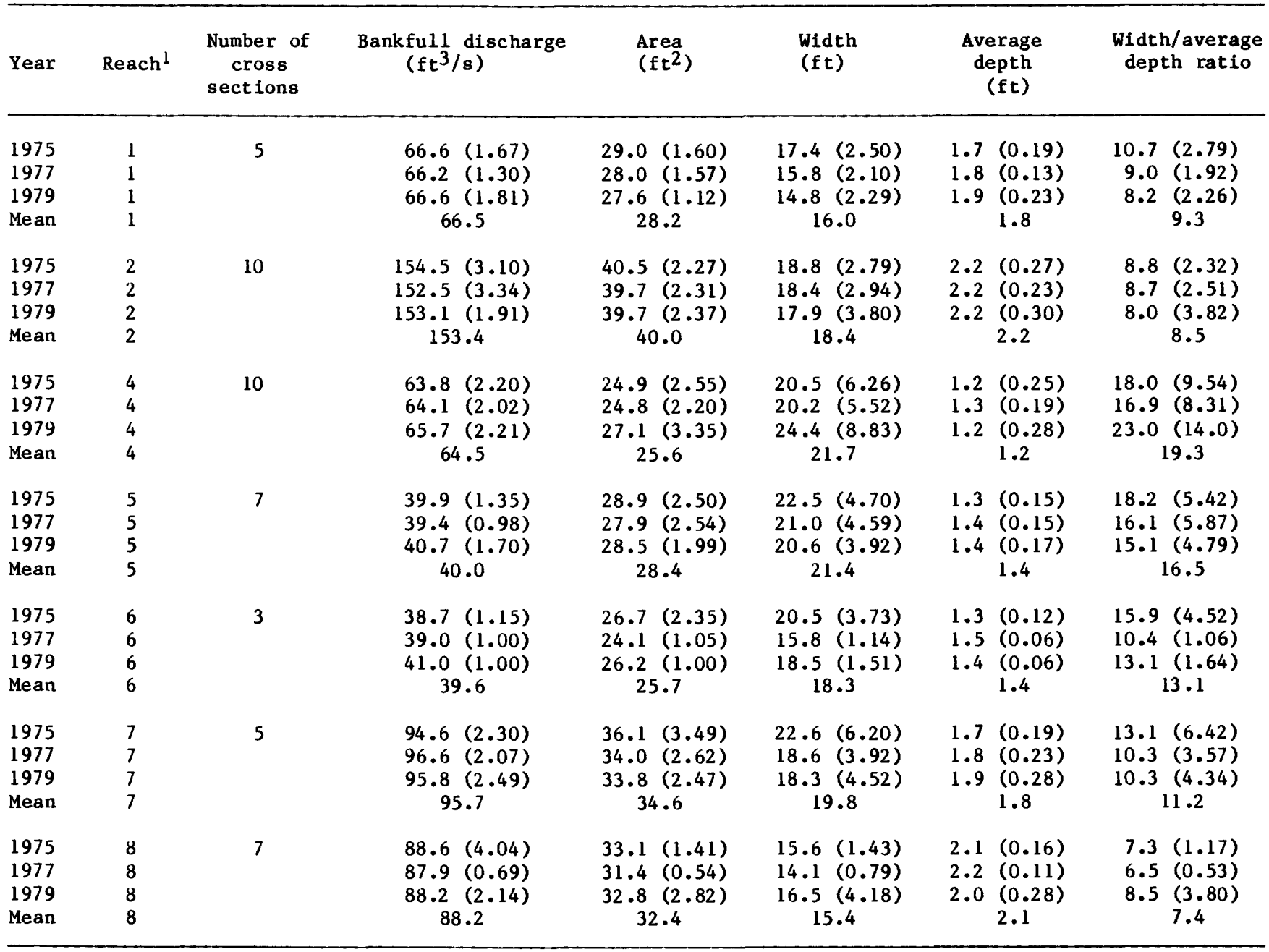

${ }^{1}$ See figure 19 for locations.

the bankfull channel downstream from the FRS has less cross-sectional area and is wider and shallower than upstream.

Changes in the channel geometry from reach 2 to reach 4 are illustrated diagrammatically in figure 21. Drainage area increases less than 10 percent between these reaches and should have only a slight effect on channel geometry. As illustrated, there is a substantial decrease in depth, with a consequent decreased cross-sectional area, at reach 4 compared with reach 2. Apparently, increased sedimentation below the FRS has occurred primarily on the channel bottom. Preferential deposition on the channel bottom is reasonable because lower stages result from the decreased streamflows below the FRS. The slight widening of the channel at reach 4 , as indicated on figure 21 , is easily explained by the small increase in drainage area and general variability of the channel. Thus, the large increase in $w / \bar{d}$ ratio downstream from the FRS results primarily from a decrease in $\bar{d}$.

Proceeding downstream from reach 4, the mean channel width decreases, and the mean depth increases (fig. 22); however, the w/ $\bar{d}$ ratio does not recover to the value at reach 2 until downstream from reach 7 (1.5 mi above the mouth). The crosssectional area variously increases and decreases from reach 4 to reach 8 , but undergoes a net increase consistent with the increased bankfull discharge.

The changes in channel geometry from reach 2 


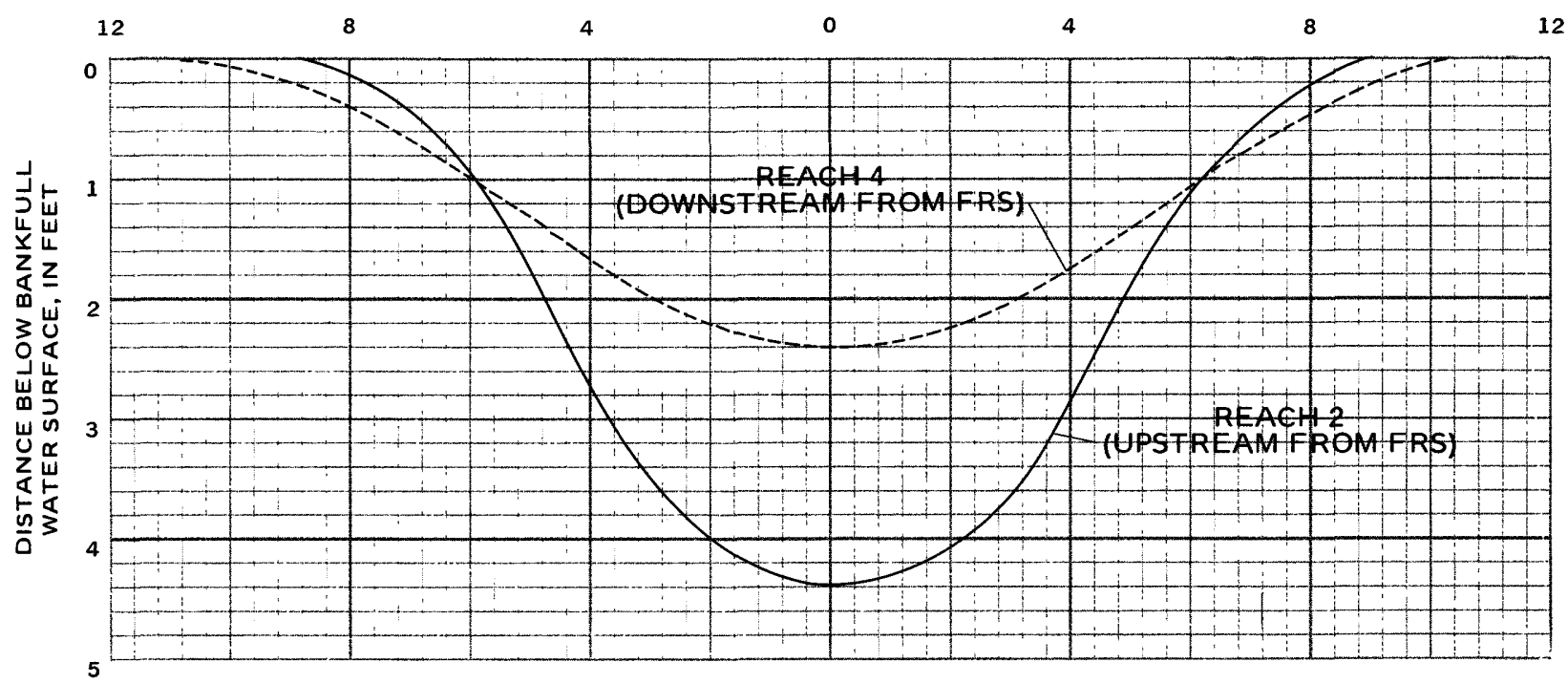

Figure 21. Diagrammatic representation of average channel geometry upstream and downstream from the flood water-retarding structure (FRS), 1975-79.

to reach 4 are a direct reflection of the effect of the FRS on bankfull discharge. As this discharge decreases from reach 2 to reach 4 , the channel requires less cross-sectional area to convey this volume of water. Below the FRS, bankfull discharge increases in proportion to drainage area, and the channel geometry reflects this increase. As measured by the $\mathrm{w} / \overline{\mathrm{d}}$ ratio, the effects of the FRS extend downstream to at least reach 7 .

\section{Hydraulic Geometry}

In addition to the cross sections associated with reaches 1, 2, and 4-8 along Trout Creek, 27 miscellaneous cross sections were surveyed in the Trout Creek basin (14 sites) and in nearby basins (13 sites). These cross sections were surveyed in 1977 and 1979 to provide data for comparison with the data from the reaches on Trout Creek. Locations of the 27 miscellaneous sites are shown in figure 23.

Hydraulic geometry describes the relationships between the channel geometry and stream discharge. In homogeneous drainage areas, such as those represented by Trout Creek and nearby basins, hydraulic geometry at bankfull discharge can be described by the equations

and

$$
\begin{aligned}
& \mathrm{w}=\mathrm{aQ}_{\mathrm{B}_{\mathrm{f}}}{ }^{\mathrm{b}}, \\
& \mathrm{d}=\mathrm{cQ}_{\mathrm{B}},
\end{aligned}
$$

$$
\overline{\mathrm{u}}=\mathrm{kQ}_{\mathrm{B}}{ }^{\mathrm{m}} \text {, }
$$

where $\bar{u}$ is the mean stream velocity $(Q / A)$. The coefficients $a, c$, and $k$ and the exponents $b, f$, and $\mathrm{m}$ can be determined empirically from measure- ments of $w, \bar{d}$, and $\bar{u}$. Since

$$
\mathrm{A}=\mathrm{w} \overline{\mathrm{d}} \text {, }
$$

multiplying equations 4 and 5 yields

where

$$
A=a^{\prime} Q_{B}{ }^{\prime},
$$

and

$$
\mathbf{a}^{\prime}=\mathbf{a c}
$$

Also, from the continuity equation,

$$
\mathrm{Q}=\mathrm{w} \overline{\mathrm{du}} \text {, }
$$

it follows that

$$
\mathbf{a} \times \mathbf{c} \times \mathbf{k}=1
$$

and

$$
b+f+m=1 \text {. }
$$

The bankfull discharges, as determined from Manning's equation, and the channel geometry for the miscellaneous sites and reaches 1 and 2 (above the FRS) were subjected to regression analysis to determine the coefficients and exponents in equations 4,5 , and 8 . The regression results are presented in table 11 and are plotted in figures 24 to 26 along with the data. All regression equations are significant at the 0.01 percent probability level. The equation for velocity in tablel1 is not a regression equation, but was calculated based on equations 12 and 13.

Figures 24-26 show that the cross-sectional properties at bankfull discharge for reaches 7 and 8 are similar to predicted values. Reach 4 , on the other hand, has a smaller mean depth and a larger width than predicted. This generally supports the conclusion of sedimentation immediately downstream from the FRS. Because the estimated bank- 

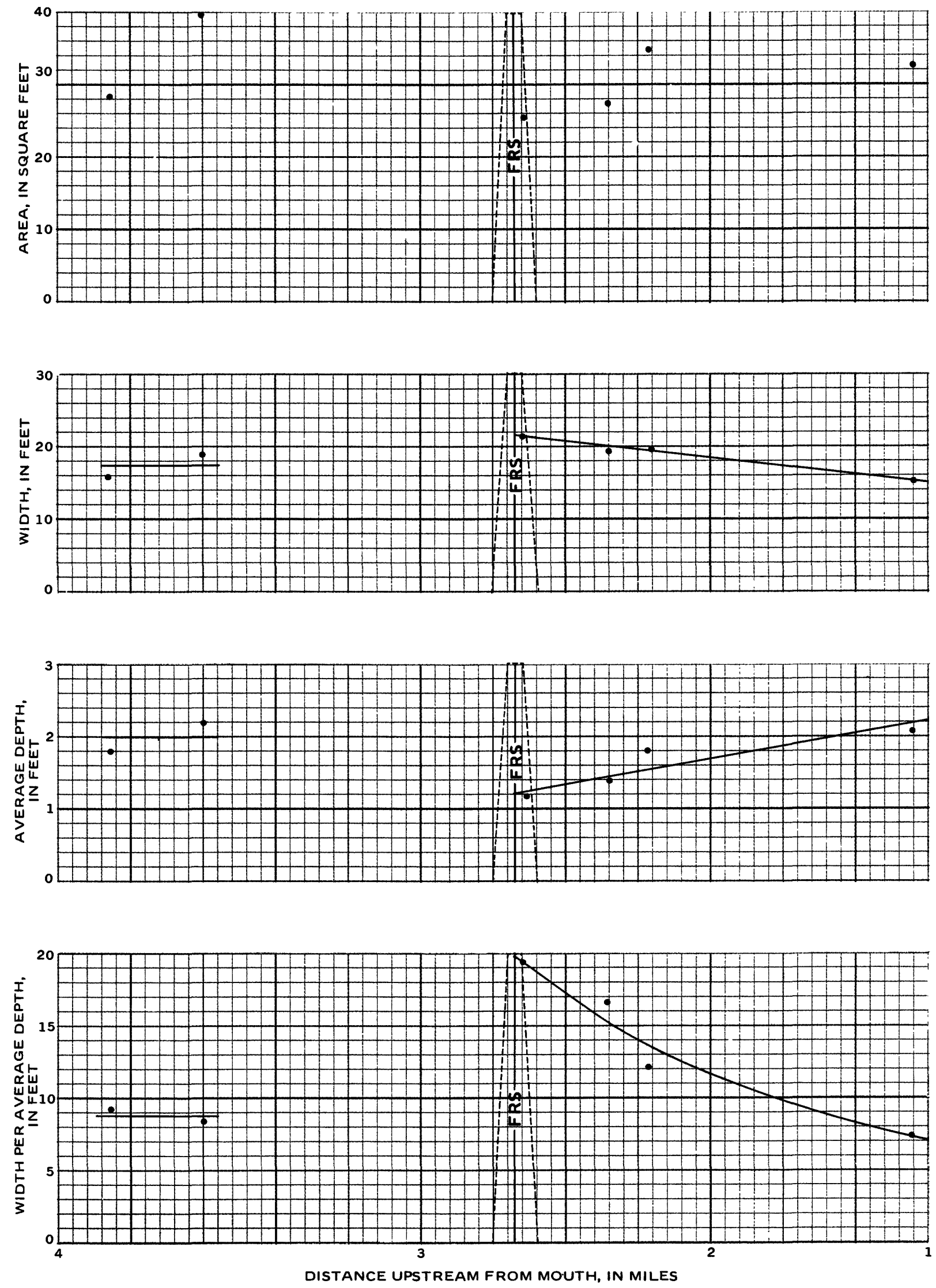

Figure 22. Average channel geometry, 1975-79. 


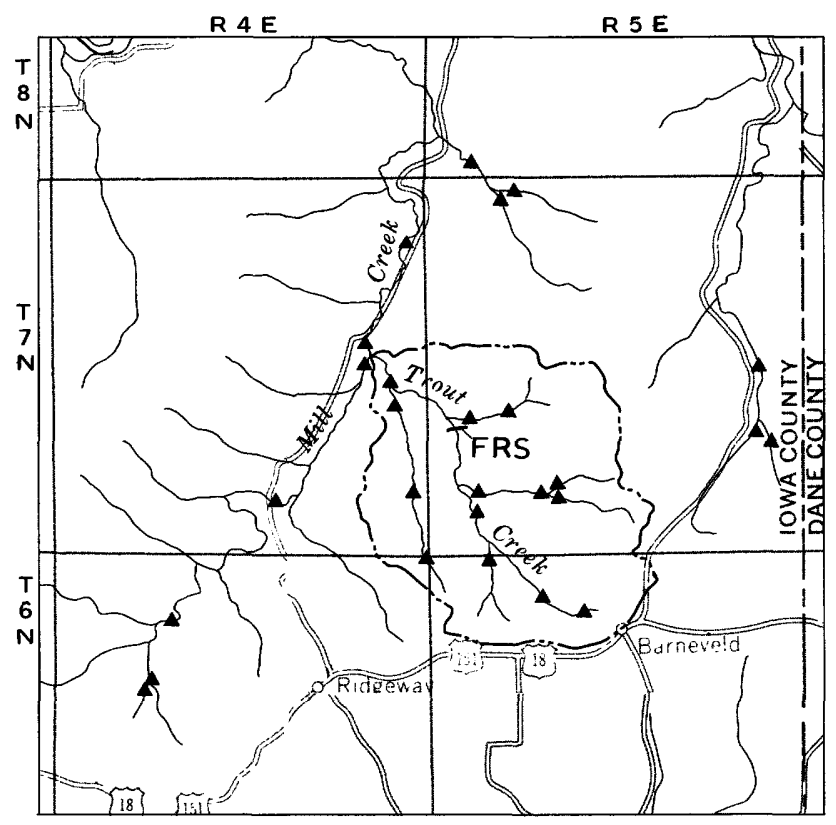

Figure 23. Locations of miscellaneous channelmorphology sites, Trout Creek basin and vicinity. full discharges at reaches 5 and 6 may be low, their hydraulic geometry will not be discussed.

A comparison of coefficients and exponents determined for the Trout Creek basin and vicinity with values reported for other areas of the United States is presented in table 12. Reasonable agreement among the various data is noted.

\section{Channel Morphology and Drainage Area}

Various studies have shown that the bankfull discharge is related to drainage area in homogeneous regions by an equation of the form

$$
Q_{B}=c^{\prime}(D A)^{n^{\prime}} \text {, }
$$

where $\mathrm{DA}$ is the drainage area (Dunne and Leopold, 1978). As the various channel cross-sectional properties--w, $\overline{\mathrm{d}}$, and A--are proportional to bankfull discharge, these properties also should be proportional to drainage area.

Regression analysis was used to develop relationships between bankfull discharge and drainage area and between the channel geometry and drain-

Table 11. Hydraulic geometry at bankfull discharge, Trout Creek basin and vicinity, $1975-79$.

[w, $\bar{d}$, in $f t ; A$, in $\mathrm{ft}^{2} ; \overline{\mathrm{u}}$, in $\mathrm{ft} / \mathrm{s} ; \mathrm{Q}_{B}$, in $\mathrm{ft}^{3} / \mathrm{s}$ ]

Equation

Coefficient

Exponent

Proportion of variation

explained $\left(r^{2}\right)$
$\mathbf{w}=\mathrm{aQ}_{\mathrm{B}} \mathrm{b}^{\mathrm{b}}$
1.16
0.56
0.887
$\overline{\mathrm{d}}=\mathrm{CQ}_{\mathrm{B}} \mathrm{f}$
0.32
0.39
0.788
$A=a^{\prime} Q_{B} b^{\prime}$
0.39
0.95
0.898
$\overrightarrow{\mathbf{u}}=\mathrm{kQ}_{\mathrm{B}} \mathrm{m}$
12.7
$1_{0.05}$

${ }^{1}$ Values for $k$ and $m$ were calculated from equations 12 and 13 . 


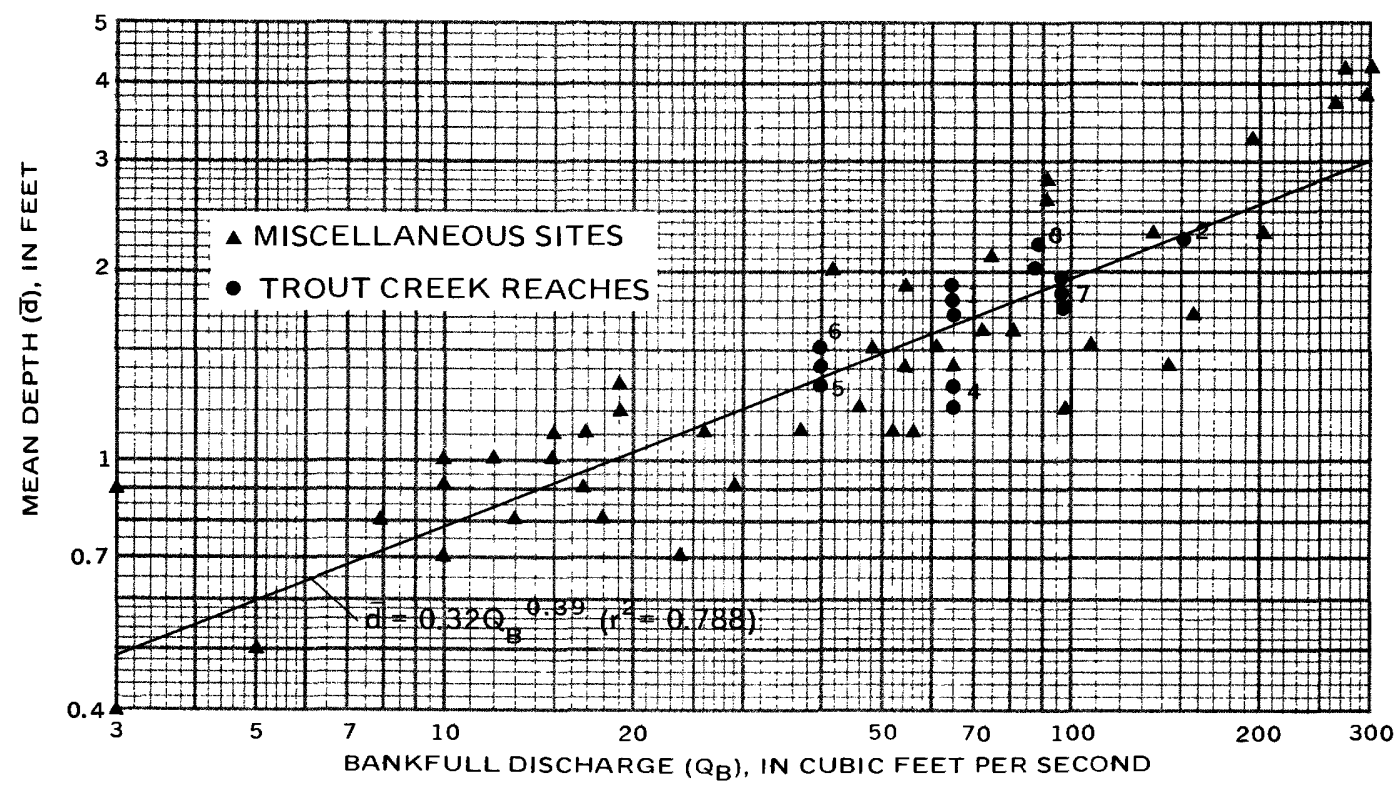

Figure 24. Relationship of mean channel depth to bankfull discharge, Trout Creek basin and vicinity, 1975-79.

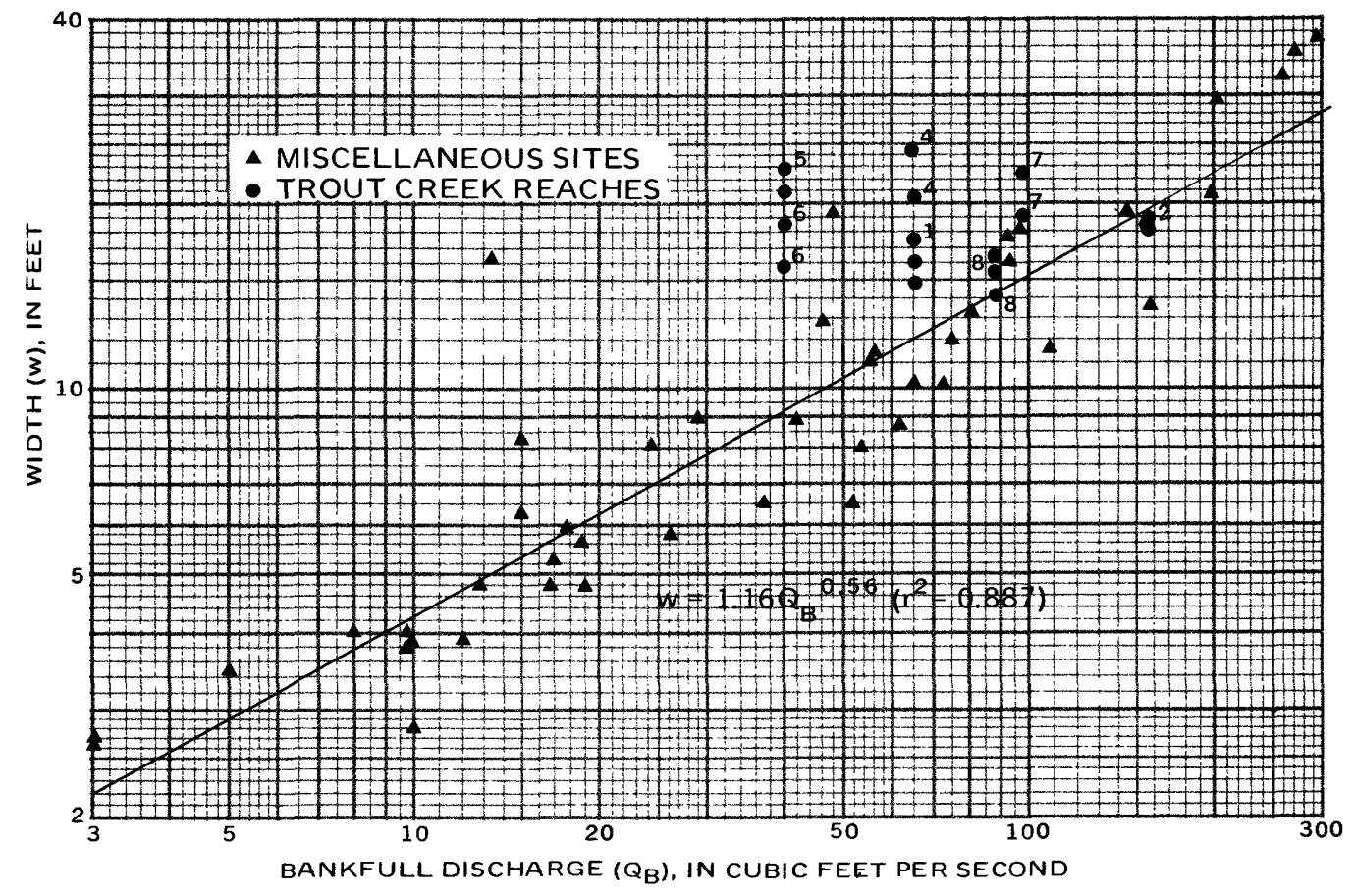

Figure 25. Relationship of channel width to bankfull discharge, Trout Creek basin and vicinity, 1975-79. 


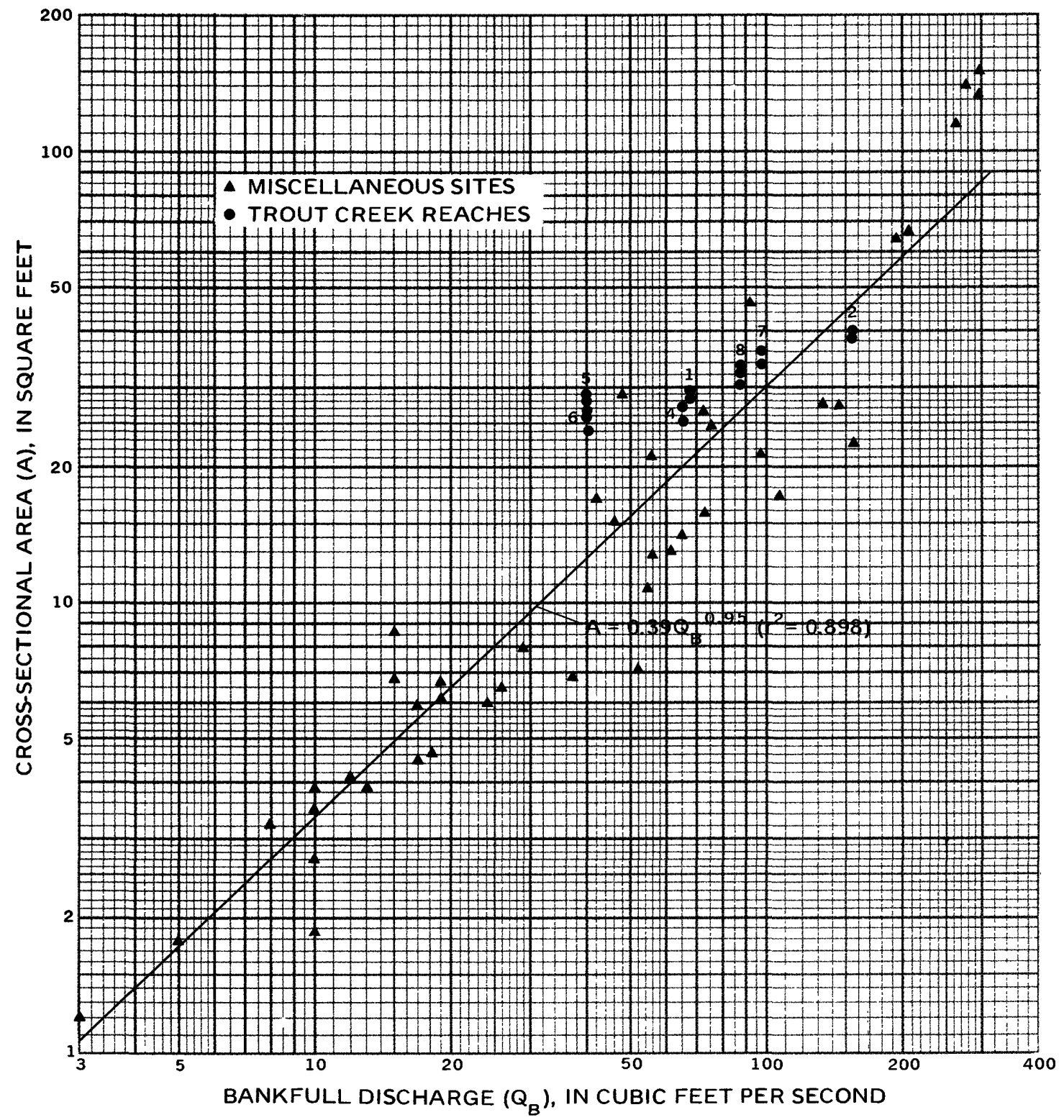

Figure 26. Relationship of channel cross-sectional area to bankfull discharge, Trout Creek basin and vicinity, 1975-79.

age area in the Trout Creek basin and vicinity. These relationships are presented in table 13 and in figures 27 to 30 along with the data. All equations are significant at the 0.01 percent probability level; however, the percentage of variation explained is considerably less than for the hydraulic geometry. In particular, only 31.8 percent of the variation in bankfull discharge can be attributed to variations in drainage area, and bankfull discharges predicted by this equation should be interpreted with caution.

To support the argument regarding increased sedimentation on the channel bottom downstream from the FRS, the mean depth at reach 4 should be less than that predicted by drainage area. Also, the width should be greater than the predicted value. Indeed, figures 28 to 30 show that this is the case, despite the considerable scatter in the data. As before, cross-sectional properties at reaches 7 and 8 are similar to predicted values (figs. 28-30).

Table 14 shows coefficients and exponents for the equations in table 13 based on studies in other areas of the United States. The data for the Trout Creek area are in close agreement with those of the Upper Salmon River, except for the value of $n^{\prime}$. In 
Table 12. Comparisons of hydraulic geometry at bankfull discharge.

\begin{tabular}{|c|c|c|c|c|c|c|}
\hline Coefficient ${ }^{l}$ & $\begin{array}{l}\text { Trout Creek basin } \\
\text { and vicinity } \\
\text { (this study) }\end{array}$ & $\begin{array}{l}\text { Upper } \\
\text { Idaho }\end{array}$ & $\begin{array}{l}\text { Salmon River, } \\
\text { (Emmett, 1975) }\end{array}$ & $\begin{array}{r}\text { Yukon } \\
\text { Alaska }\end{array}$ & $\begin{array}{l}\text { River region, } \\
\text { (Emmett, 1972) }\end{array}$ & $\begin{array}{l}\text { Upper Green River, } \\
\text { Wyoming (Dunne and } \\
\text { Leopold, 1978) }\end{array}$ \\
\hline $\begin{array}{l}a \\
c \\
a^{\prime} \\
k\end{array}$ & $\begin{array}{r}1.16 \\
.32 \\
.39 \\
2.7\end{array}$ & & $\begin{array}{r}1.37 \\
.25 \\
.35 \\
2.88\end{array}$ & & $\begin{array}{r}1.70 \\
.53 \\
.89 \\
1.14\end{array}$ & $\begin{array}{l}--- \\
-\infty \\
---\end{array}$ \\
\hline
\end{tabular}

Exponent ${ }^{1}$

\begin{tabular}{|c|c|c|c|c|}
\hline $\begin{array}{l}b \\
f \\
b^{\prime} \\
m\end{array}$ & $\begin{array}{r}.56 \\
.39 \\
.95 \\
2.05\end{array}$ & $\begin{array}{r}.54 \\
.34 \\
.88 \\
.12\end{array}$ & $\begin{array}{l}.54 \\
.30 \\
.84 \\
.16\end{array}$ & $\begin{array}{r}0.55 \\
.35 \\
.10\end{array}$ \\
\hline
\end{tabular}

${ }^{1}$ See table 11 for descriptions.

${ }^{2}$ Calculated values (see table 11 ). general, bankfull discharge increases less rapidly with drainage area in the Trout Creek basin than in the Upper Salmon River basin. This probably results because a greater proportion of the annual runoff in the Upper Salmon River is from snowmelt and is concentrated during a shorter time and because smaller slopes and more permeable soils in the Trout Creek basin allow a greater proportion of the precipitation to infiltrate and discharge to the stream as base flow at stream discharges considerably less than bankfull. The latter is consistent with the high base flow in Trout Creek. Bankfull discharges increase much more rapidly with drainage area in the West Cascades and Puget Sound region, presumably because of the considerably greater precipitation.

Channel cross-sectional area increases with drainage area at about the same rate in the Trout Creek region and in the Upper Salmon River basin. As bankfull discharge increases less rapidly with drainage area in the Trout Creek basin, this implies that stream velocities are slower in the Trout Creek region for drainage basins of similar size. Though independent data are not available to confirm this, it seems reasonable to expect slower velocities in this area of generally smaller stream gradients.

\section{SUMMARY AND CONCLUSIONS}

Trout Creek has a high base flow sustained by ground-water discharge. Precipitation on the basin first recharges the ground-water system. Any excess precipitation contributes to floodflows, which transport most of the sediment into the stream channel.

The floodwater-retarding structure (FRS) in the Trout Creek basin attenuated flood peaks from $\mathbf{5 8}$ to 92 percent during the study. Most discharges from the FRS were between 58 and $71 \mathrm{ft}^{3} / \mathrm{s}$, which is approximately equal to the independently determined bankfull discharge of $65 \mathrm{ft}^{3} / \mathrm{s}$, to which the channel just downstream from the FRS has adjusted. The FRS also increased the time base of flood hydrographs.

When high flows enter the flood-storage pool, velocities decrease, and much of the transported sediment is deposited on the bottom of the deeply entrenched channel. As the stage in the flood pool drops and stream discharge decreases, velocities in the pooled channel begin to increase, and the sediment is remobilized and transported from the FRS. This contributes to the observed low net sediment- 


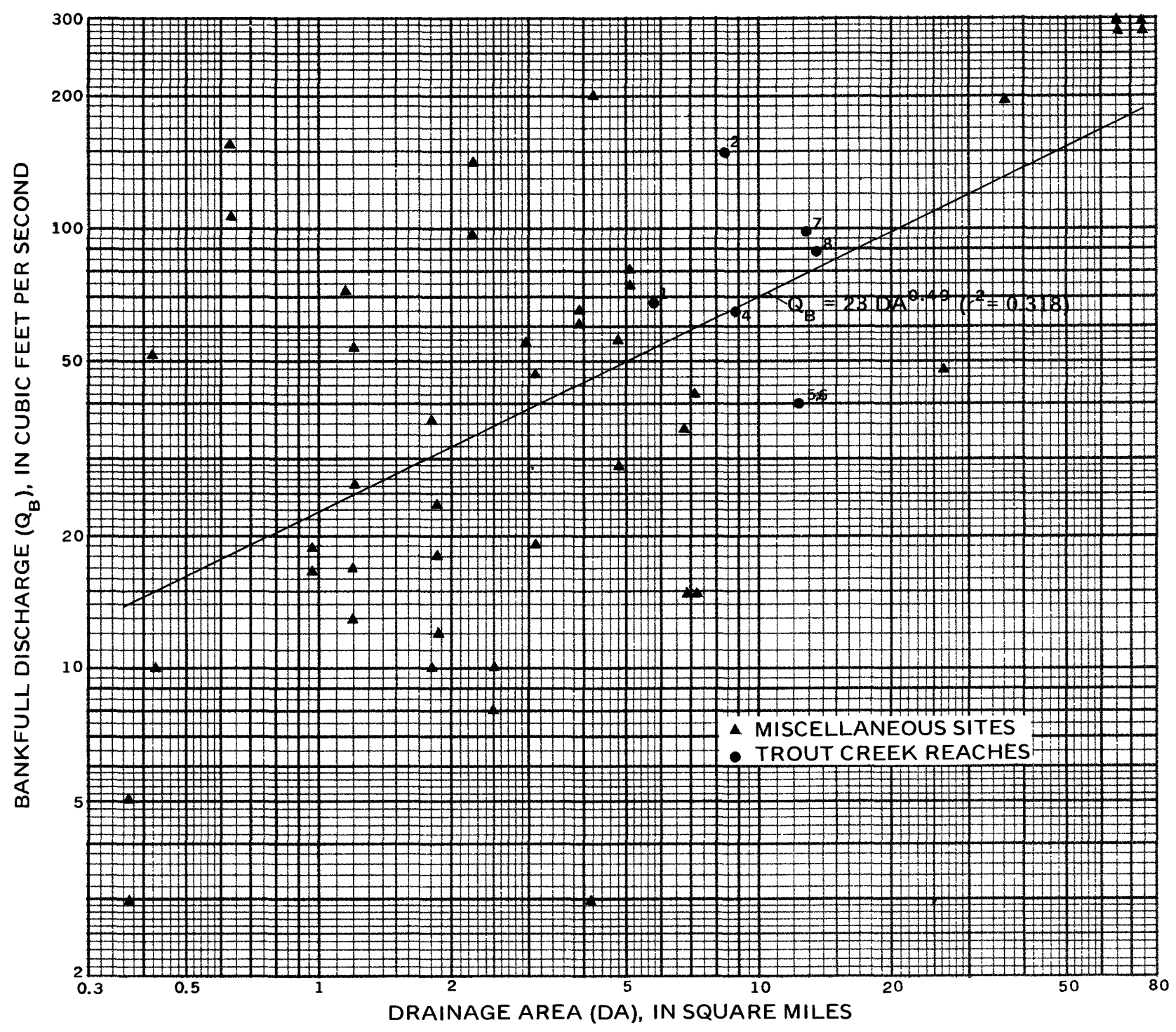

Figure 27. Relationship of bankfull discharge to drainage area, Trout Creek basin and vicinity, 1975-79.

trapping efficiency of about 7 percent during the study.

Although the net effect of the FRS on sediment yields is slight, the structure has caused considerable change in sediment-transport patterns. Suspendedsediment concentrations above the influence of the FRS are high only during floods (usually periods of several days or less); whereas, concentrations remain high below the structure for much longer periods (in some cases, several months), as sediment in the channel of the flood-storage pool upstream from the FRS is remobilized and flushed from the reservoir.

The FRS also has caused changes in the channel morphology downstream. The 30 -in. diameter pipe through the FRS has reduced bankfull capacity of the channel from $154 \mathrm{ft}^{3} / \mathrm{s}$ upstream from the FRS to $65 \mathrm{ft}^{3} / \mathrm{s}$ downstream. The reduced bankfull discharge downstream has resulted in a channel that is slightly wider and considerably shallower than upstream and when compared with those of other streams in nearby basins. The channel just down- 


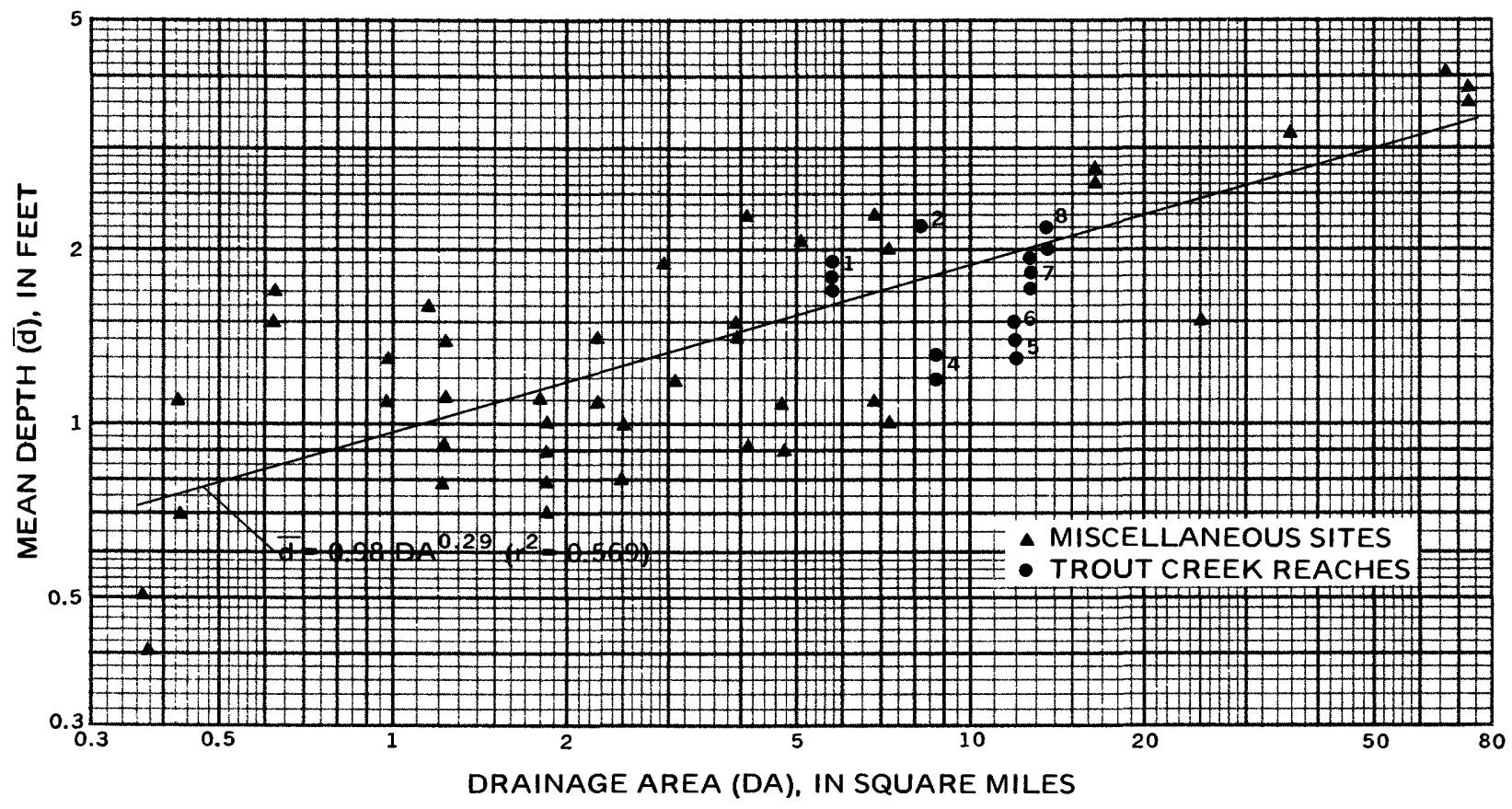

Figure 28. Relationship of mean channel depth at bankfull discharge to drainage area, Trout Creek basin and vicinity, 1975-79.

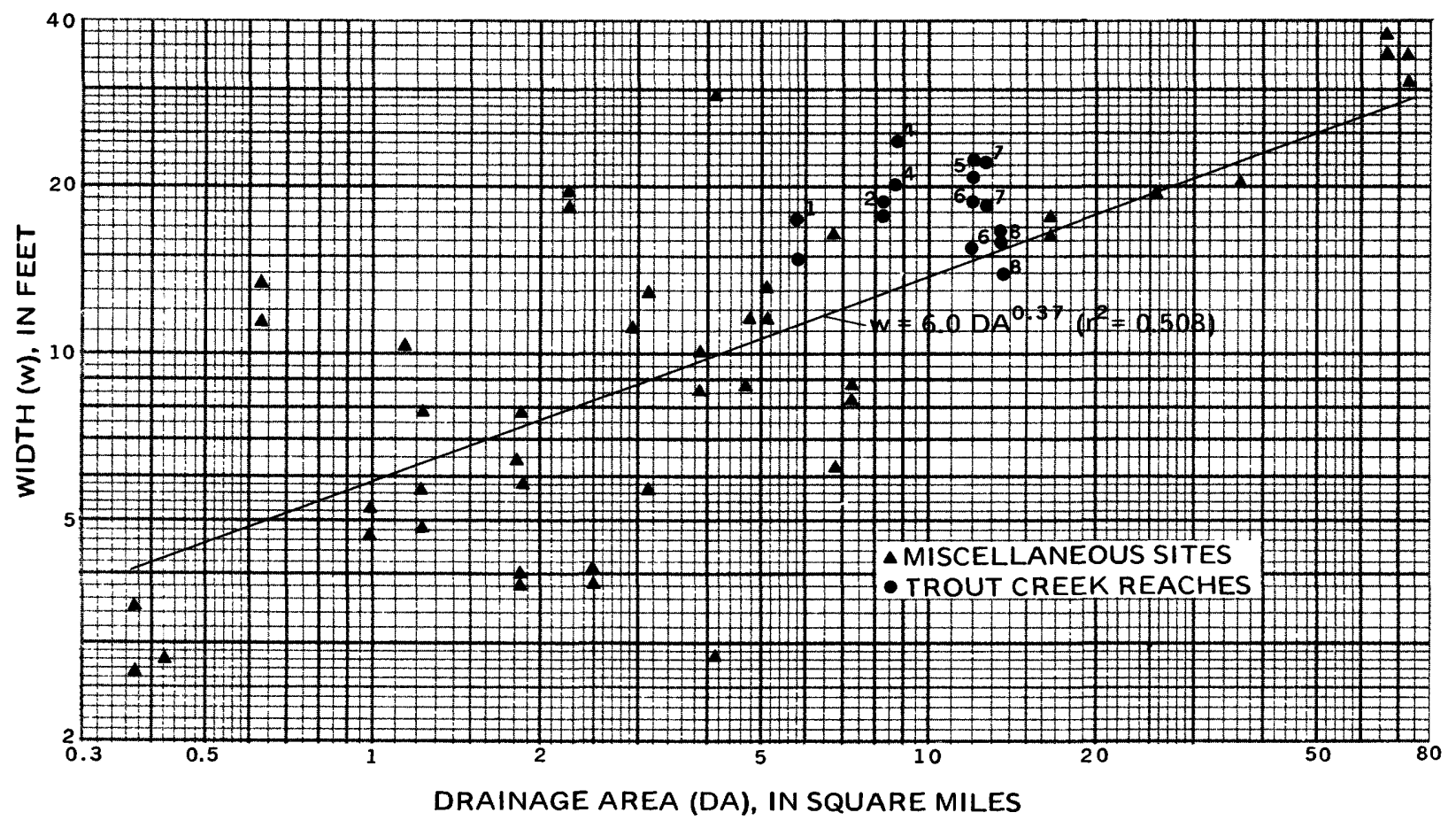

Figure 29. Relationship of channel width at bankfull discharge to drainage area, Trout Creek basin and vicinity, 1975-79. 


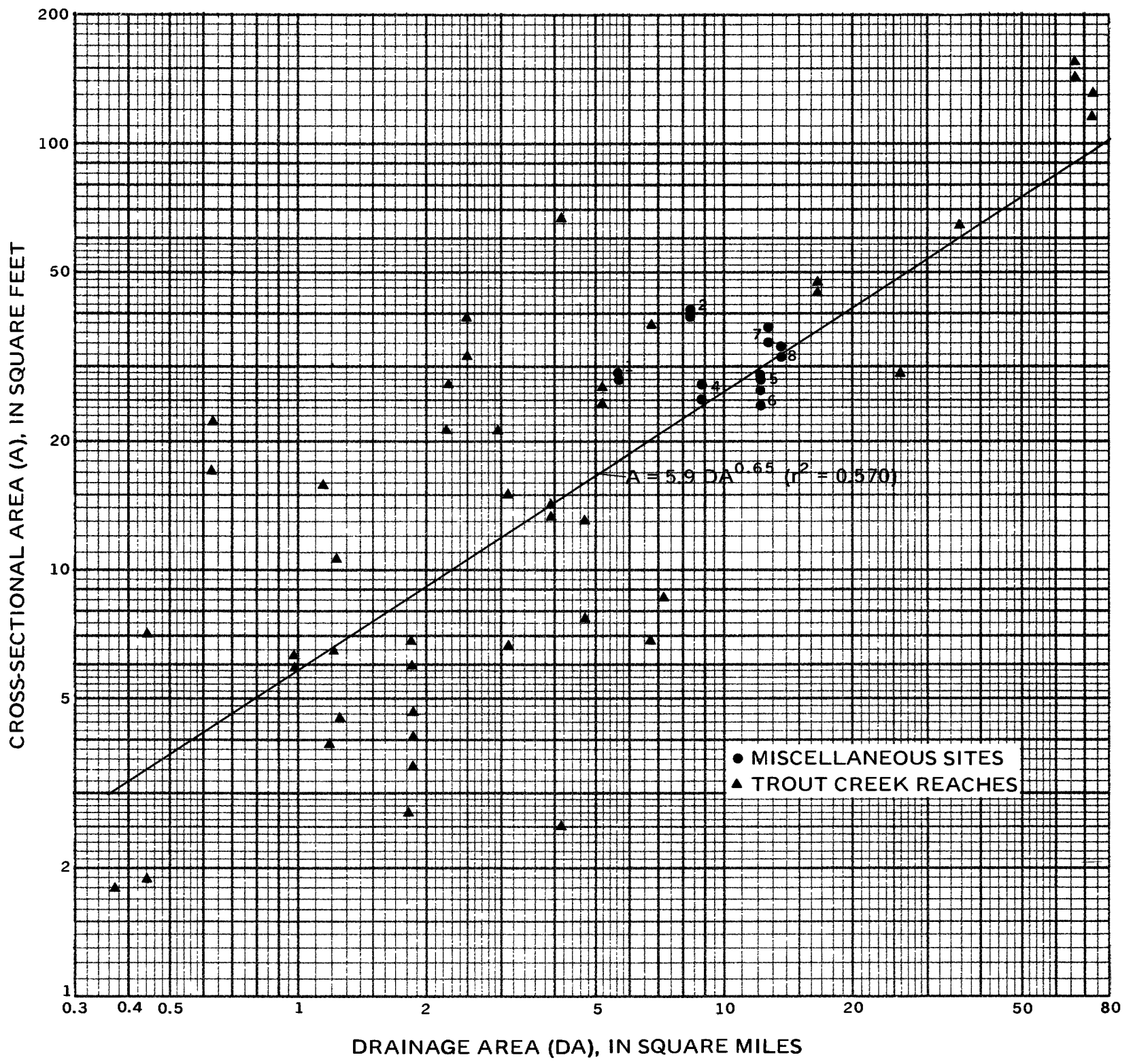

Figure 30. Relationship of channel cross-sectional area at bankfull discharge to drainage area, Trout Creek basin and vicinity, 1975-79. 
Table 13. Relationships of bankfull discharge and channel geometry to drainage area, Trout Creek basin and vicinity, 1975-79.

[QB, in $f t^{3} / s ; w, \bar{d}$, in $f t ; A$, in $f t^{2} ; D A$, in $\mathrm{mi}^{2}$ ]

$\begin{array}{ccc}\text { Equation Coefficient } & \text { Exponent } & \begin{array}{c}\text { Proportion of variation } \\ \text { explained }\left(\mathrm{r}^{2}\right)\end{array}\end{array}$

\begin{tabular}{llll}
$Q_{B}=c^{\prime} D^{n^{\prime}}$ & 23 & 0.49 & 0.318 \\
$w=o D A q$ & 6.0 & 0.37 & 0.508 \\
$\bar{d}=$ sDA $^{t}$ & 0.98 & 0.29 & 0.569 \\
$A=$ vDA $^{2}$ & 5.9 & 0.65 & 0.570 \\
\hline
\end{tabular}

Table 14. Comparisons of relationships of bankfull discharge and channel geometry to drainage area.

\begin{tabular}{|c|c|c|c|c|c|c|}
\hline Coefficient ${ }^{l}$ & $\begin{array}{l}\text { Trout Creek } \\
\text { basin and } \\
\text { vicinity } \\
\text { (this study) }\end{array}$ & $\begin{array}{l}\text { Upper Salmon } \\
\text { River, Idaho } \\
\text { (Emmett, 1975) }\end{array}$ & $\begin{array}{l}\text { Yukon River } \\
\text { region, Alaska } \\
\text { (Emmett, 1971) }\end{array}$ & $\begin{array}{l}\text { Upper Green } \\
\text { RIver, Wyoming } \\
\text { (Dunne and } \\
\text { Leopold, 1978) }\end{array}$ & $\begin{array}{l}\text { Pennsyl vania } \\
\text { (Dunne and } \\
\text { Leopold, 1978) }\end{array}$ & $\begin{array}{l}\text { West Cascades } \\
\text { and Puget Sound } \\
\text { (Dunne and } \\
\text { Leopold, 1978) }\end{array}$ \\
\hline $\begin{array}{l}c^{\prime} \\
0 \\
8 \\
v\end{array}$ & $\begin{array}{c}23 \\
6.0 \\
.98 \\
5.9\end{array}$ & $\begin{array}{c}28 \\
8.1 \\
.69 \\
5.6\end{array}$ & $\begin{array}{c}27.1 \\
9.63 \\
1.43 \\
13.7\end{array}$ & ב6 & $\begin{array}{l}61 \\
---- \\
----\end{array}$ & 55 \\
\hline
\end{tabular}

Exponent ${ }^{1}$

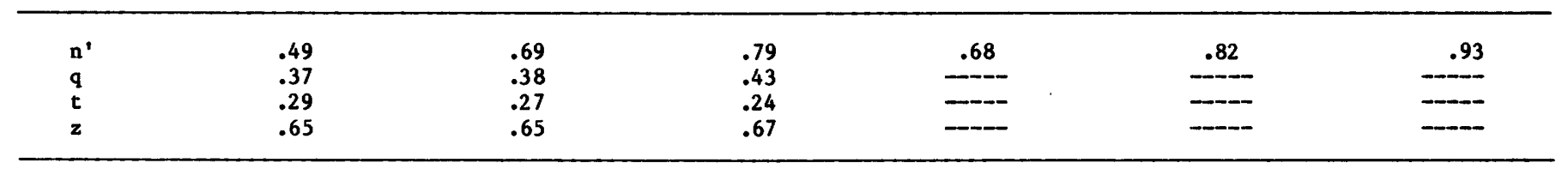

${ }^{1}$ See table 13 for description.

stream from the FRS has adjusted to reduced streamflow by depositing sediment transported from the FRS during low flows. As the bankfull capacity at this point is about equal to the FRS outflow, the channel may be in equilibrium with the current hydrologic regime. Farther downstream, near the mouth of Trout Creek, channel geometry and hydraulic geometry relationships indicate little effect of the FRS. A pipe designed to pass the bankfull discharge that existed before FRS construction would have minimized downstream changes in channel morphology and sediment transport.

Evidence suggests that, in the past, debris lodged in the inlet of the FRS has caused increased sedimentation in the channel of the flood pool. This resulted because water was impounded for a longer period than expected. Improved maintenance of the FRS during this study apparently prevented recurrence of this phenomenon and precluded its documentation. 


\title{
Arthropod Fauna
}

\author{
By William L. Hilsenhoff ${ }^{1}$
}

\section{INTRODUCTION}

In April 1975, a study was initiated to evaluate effects of a floodwater-retarding structure (FRS) on the arthropod fauna of Trout Creek, Iowa County, Wis., and to document the fauna. This research was supported by the College of Agricultural and Life Sciences, University of Wisconsin, Madison, by the U.S. Soil Conservation Service, and by the Wisconsin Department of Natural Resources.

\section{METHODS}

Six study sites were established: three upstream from and three downstream from the FRS (fig. 31). All sites were gravel riffles; sites 3 and 4 were the closest riffles to the FRS at the time the study began. Two samples were collected from each site in mid-April, mid-June, mid-August, and midOctober of 1975, 1976, 1977, and 1979. Additional samples were collected on February 25,1976 . In 1978 , additional insects were collected for laboratory rearing to enable species determination of some genera whose immature stages could be identified. Representative specimens of all species collected (at least 94) have been deposited in the University of Wisconsin collection.

At each site, two different riffles or different parts of the same riffle were sampled. Each sample was collected by placing a D-frame aquatic net (Wards Scientific Establishment, Rochester, New York) on the bottom, disturbing substrate above the net with one's feet, and allowing arthropods to drift into the net. The contents of the net were emptied in a shallow white pan containing a small amount of water. Arthropods clinging to the net were removed with a curved forceps and placed in a jar of 70 percent ethanol. Arthropods were similarly removed from the pan. Sample size was limited by a 15-minute period for picking arthropods from the net and the pan. Samples were sorted, identified, and enumerated in the laboratory.
A biotic-index value (Hilsenhoff, 1977) was calculated for each sample (table 15). The biotic index is a system for measuring organic pollution and related increases in trophic levels; it is a measure of oxygen depletion in the stream that results from trophism and decomposition of organic matter. Each species of arthropod is assigned a value of 0 to 5 based on its ability to tolerate oxygen depletion. A value of 0 is assigned to species unable to tolerate any oxygen depletion, and a value of 5 is assigned to species able to tolerate almost complete oxygen depletion. Intermediate values are assigned to species of intermediate tolerance. Values were initially assigned as a result of a study of 53 Wisconsin streams (Hilsenhoff, 1977); these values were revised in November 1980 after a study of more than 1,000 additional streams. Biotic-index values are always highest in summer, but adequate seasonal correction factors have not yet been developed. Using an average of spring and autumn biotic-index values, Wisconsin streams can be rated as follows:

Biotic Index Water quality State of the stream

$0-1.75$ Excellent No organic pollution

1.75-2.25 Very good Possible slight pollution

2.25-2.75 Good Some organic pollution

2.75-3.50 Fair Significant pollution

3.50-4.25 Poor Very significant pollution

4.25-5.00 Very poor Severe organic pollution

\section{RESULTS AND DISCUSSION}

When the study began, sediment depths in the stream channel between the FRS an site 3 were $1.5 \mathrm{ft}$ or more, apparently a result of obstruction by debris of the inlet of the pipe passing beneath the FRS. When the debris was removed and the inlet was kept free of obstructions, the sediment was washed from the channel upstream from the FRS. This took several weeks and caused the area downstream to be extremely turbid during late summer of 1975; there seemed to be no direct effect on the arthropod fauna. The riffle at site 3 , however, enlarged significantly, resulting in an increase of some species subsequent to 1975 . This was reflected

\footnotetext{
${ }^{1}$ Department of Entomology, University of Wisconsin, Madison Wisconsin.
} 


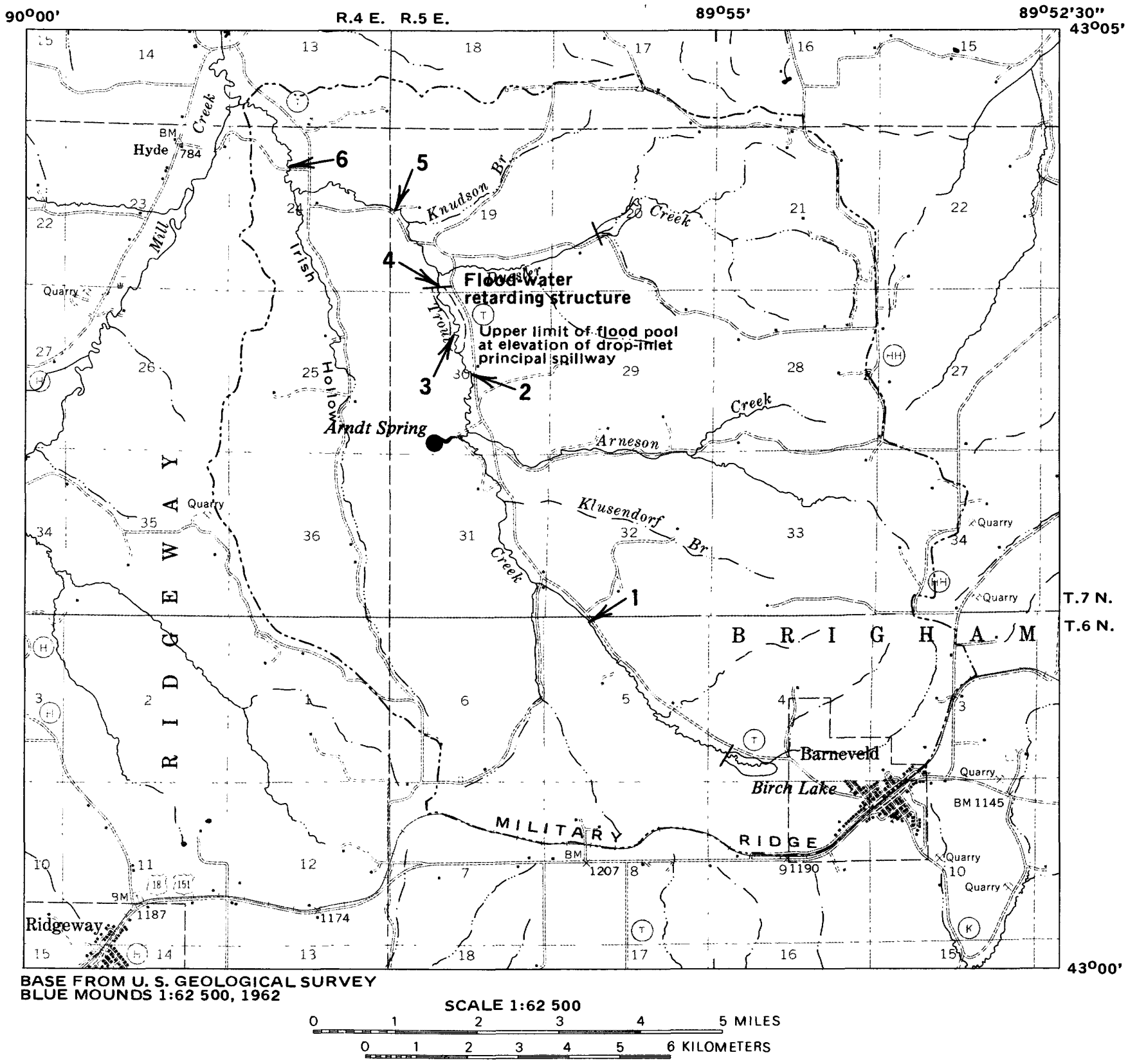

Figure 31. Locations of sampling sites for collection of arthropod fauna.

in the biotic-index values, which decreased after 1975. Considerable sediment also was deposited at site 4 in 1976, which temporarily reduced the fauna at that site and increased biotic-index values.

A yearly average biotic-index value greater than 1.75 indicates less than excellent water quality (Hilsenhoff, 1977 , table 6, p.10). This value generally was exceeded at site 1 and, in 1977 , at sites 5 and 6 . With these exceptions, there seems to be little differ- ence between biotic-index values for the sites upstream from the FRS and those sites downstream. Average index values were always highest at site 1, probably because of cattle pasturing upstream or the effects of Birch Lake. The significant increase in 1979 suggests more pasturing of cattle or some other upstream perturbation. The large volume of water from Arndt Spring just upstream from site 2, eliminated any effect on sites farther downstream. However, in 1977, biotic-index values rose signifi- 
Table 15. Biotic-index values.

\begin{tabular}{|c|c|c|c|c|c|c|c|c|}
\hline \multirow[b]{2}{*}{ Month } & \multirow[b]{2}{*}{ Year } & \multicolumn{6}{|c|}{ Site } & \multirow[b]{2}{*}{ Average } \\
\hline & & 1 & 2 & 3 & 4 & 5 & 6 & \\
\hline February & 1976 & 1.79 & 1.36 & 1.25 & 1.10 & 1.07 & 1.03 & 1.27 \\
\hline $\begin{array}{l}\text { April } \\
\text { April } \\
\text { April } \\
\text { April } \\
\text { April }\end{array}$ & $\begin{array}{l}1975 \\
1976 \\
1977 \\
1979 \\
\text { Average }\end{array}$ & $\begin{array}{l}1.61 \\
1.45 \\
1.52 \\
1.78 \\
1.59 \\
\end{array}$ & $\begin{array}{l}1.24 \\
1.07 \\
1.11 \\
1.12 \\
1.14 \\
\end{array}$ & $\begin{array}{l}1.16 \\
1.15 \\
1.13 \\
1.12 \\
1.14 \\
\end{array}$ & $\begin{array}{l}1.03 \\
1.14 \\
1.02 \\
1.10 \\
1.07 \\
\end{array}$ & $\begin{array}{l}1.05 \\
1.16 \\
1.09 \\
1.03 \\
1.08 \\
\end{array}$ & $\begin{array}{l}1.06 \\
1.04 \\
1.10 \\
1.09 \\
1.07 \\
\end{array}$ & $\begin{array}{l}1.19 \\
1.17 \\
1.16 \\
1.21 \\
1.18 \\
\end{array}$ \\
\hline $\begin{array}{l}\text { June } \\
\text { June } \\
\text { June } \\
\text { June } \\
\text { June }\end{array}$ & $\begin{array}{l}1975 \\
1976 \\
1977 \\
1979 \\
\text { Average }\end{array}$ & $\begin{array}{l}1.70 \\
2.00 \\
1.80 \\
2.42 \\
1.98 \\
\end{array}$ & $\begin{array}{l}1.36 \\
1.48 \\
1.29 \\
1.90 \\
1.51 \\
\end{array}$ & $\begin{array}{l}1.76 \\
1.53 \\
1.21 \\
1.40 \\
1.48 \\
\end{array}$ & $\begin{array}{l}1.18 \\
1.38 \\
1.10 \\
1.30 \\
1.24 \\
\end{array}$ & $\begin{array}{l}1.53 \\
1.25 \\
1.64 \\
1.34 \\
1.44 \\
\end{array}$ & $\begin{array}{l}1.28 \\
1.21 \\
2.12 \\
1.33 \\
1.49 \\
\end{array}$ & $\begin{array}{l}1.47 \\
1.48 \\
1.53 \\
1.62 \\
1.52 \\
\end{array}$ \\
\hline $\begin{array}{l}\text { August } \\
\text { August } \\
\text { August } \\
\text { August } \\
\text { August }\end{array}$ & $\begin{array}{l}1975 \\
1976 \\
1977 \\
1979 \\
\text { Average }\end{array}$ & $\begin{array}{l}1.73 \\
1.95 \\
2.18 \\
2.41 \\
2.07 \\
\end{array}$ & $\begin{array}{l}1.88 \\
1.75 \\
1.54 \\
1.77 \\
1.74 \\
\end{array}$ & $\begin{array}{l}1.95 \\
1.37 \\
1.32 \\
1.39 \\
1.48 \\
\end{array}$ & $\begin{array}{l}1.93 \\
1.70 \\
1.88 \\
1.61 \\
1.78 \\
\end{array}$ & $\begin{array}{l}2.06 \\
1.65 \\
2.26 \\
1.75 \\
1.93 \\
\end{array}$ & $\begin{array}{l}1.69 \\
2.03 \\
2.23 \\
1.82 \\
1.94 \\
\end{array}$ & $\begin{array}{l}1.87 \\
1.74 \\
1.90 \\
1.79 \\
1.82 \\
\end{array}$ \\
\hline $\begin{array}{l}\text { October } \\
\text { October } \\
\text { October } \\
\text { October } \\
\text { October }\end{array}$ & $\begin{array}{l}1975 \\
1976 \\
1977 \\
1979 \\
\text { Average }\end{array}$ & $\begin{array}{l}1.91 \\
1.95 \\
2.04 \\
2.16 \\
2.02 \\
\end{array}$ & $\begin{array}{l}1.49 \\
1.44 \\
1.34 \\
1.29 \\
1.39 \\
\end{array}$ & $\begin{array}{l}1.77 \\
1.26 \\
1.64 \\
1.17 \\
1.46 \\
\end{array}$ & $\begin{array}{l}1.85 \\
1.72 \\
1.76 \\
1.74 \\
1.77 \\
\end{array}$ & $\begin{array}{l}1.69 \\
1.66 \\
2.13 \\
1.63 \\
1.78 \\
\end{array}$ & $\begin{array}{l}1.76 \\
1.86 \\
2.09 \\
1.74 \\
1.86 \\
\end{array}$ & $\begin{array}{l}1.75 \\
1.65 \\
1.83 \\
1.62 \\
1.71 \\
\end{array}$ \\
\hline Average by & site & 1.92 & 1.45 & 1.39 & 1.47 & 1.56 & 1.59 & \\
\hline $\begin{array}{l}\text { Average } \\
\text { Average } \\
\text { Average } \\
\text { Average }\end{array}$ & $\begin{array}{l}1975 \\
1976 \\
1977 \\
1979\end{array}$ & $\frac{\frac{1.74}{1.84}}{\frac{1.89}{2.19}}$ & $\frac{\frac{1.49}{1.44}}{\frac{1.32}{1.52}}$ & $\frac{\frac{1.66}{1.33}}{\frac{1.33}{1.27}}$ & $\frac{\frac{1.50}{1.49}}{\frac{1.44}{1.44}}$ & $\frac{\frac{1.58}{1.43}}{\frac{1.78}{1.44}}$ & $\frac{\frac{1.45}{1.54}}{\frac{1.89}{1.50}}$ & $\frac{\frac{1.57}{1.51}}{\frac{1.61}{1.56}}$ \\
\hline
\end{tabular}

cantly in June, August, and October at sites 5 and 6. This suggests some organic pollution, perhaps the result of more intensive cattle pasturing below the FRS. In 1979, the biotic index indicated this section of the stream had returned to its former condition.

\section{SUMMARY AND CONCLUSIONS}

Downstream from Arndt Spring, Trout Creek has excellent water quality (biotic indices less than
1.75) and a large diverse arthropod fauna that has not been affected by the FRS. Between Arndt Spring and Birch Lake slight organic pollution is indicated by the arthropod fauna.

The distribution and abundance of the most common arthropods sampled in Trout Creek are summarized in table 16 . Because only riffles were sampled, arthropods that inhabit other habitats-such as, the bank vegetation, roots under the bank, pieces of decaying wood, or pools--may not be represented. 
Table 16. Numbers of each species of arthropod collected by site, month, and year.

\begin{tabular}{|c|c|c|c|c|c|c|c|c|c|c|c|c|c|c|c|}
\hline \multirow[b]{2}{*}{ Species } & \multicolumn{6}{|c|}{ Site } & \multicolumn{5}{|c|}{ Month } & \multicolumn{4}{|c|}{ Year } \\
\hline & 1 & 2 & 3 & 4 & 5 & 6 & Feb. & Apr. & June & Aug. & Oct. & 1975 & 1976 & 1977 & 1979 \\
\hline $\begin{array}{l}\text { Isoperla signata } \\
\text { Isoperla } \\
\text { Isoperla } \\
\text { Baetis issonae } \\
\text { Baetis } \frac{\text { brunsmarina }}{\text { flavistriga }}\end{array}$ & $\begin{array}{r}98 \\
0 \\
0 \\
424 \\
147\end{array}$ & $\begin{array}{r}73 \\
24 \\
0 \\
195 \\
326\end{array}$ & $\begin{array}{r}16 \\
29 \\
6 \\
507 \\
152\end{array}$ & $\begin{array}{r}32 \\
18 \\
14 \\
445 \\
335\end{array}$ & $\begin{array}{r}18 \\
39 \\
114 \\
356 \\
123\end{array}$ & $\begin{array}{r}6 \\
24 \\
82 \\
1,182 \\
416\end{array}$ & $\begin{array}{r}256 \\
148 \\
232 \\
0 \\
0\end{array}$ & $\begin{array}{r}173 \\
22 \\
109 \\
0 \\
0\end{array}$ & $\begin{array}{r}0 \\
0 \\
0 \\
448 \\
695\end{array}$ & $\begin{array}{r}0 \\
0 \\
0 \\
692 \\
556\end{array}$ & $\begin{array}{r}6 \\
75 \\
49 \\
1,969 \\
248\end{array}$ & $\begin{array}{r}45 \\
35 \\
28 \\
881 \\
604\end{array}$ & $\begin{array}{r}61 \\
23 \\
24 \\
687 \\
212\end{array}$ & $\begin{array}{r}49 \\
23 \\
96 \\
895 \\
472\end{array}$ & $\begin{array}{r}24 \\
16 \\
10 \\
646 \\
211\end{array}$ \\
\hline $\begin{array}{l}\frac{\text { Baet1s }}{\text { Pseudocloeon }} \frac{\text { vagans }}{\text { dublum }} \\
\frac{\text { Pseudocloeon }}{\text { Ephemerella }} \text { sp. } \\
\text { Peptagenta } \\
\text { Heptabasia }\end{array}$ & $\begin{array}{r}661 \\
0 \\
0 \\
1,166 \\
0\end{array}$ & $\begin{array}{r}939 \\
2 \\
0 \\
5,410 \\
2\end{array}$ & $\begin{array}{r}966 \\
165 \\
0 \\
4,043 \\
1\end{array}$ & $\begin{array}{r}494 \\
21 \\
2 \\
6,581 \\
0\end{array}$ & $\begin{array}{r}419 \\
6 \\
0 \\
3,962 \\
64\end{array}$ & $\begin{array}{r}507 \\
6 \\
40 \\
3,290 \\
93\end{array}$ & $\begin{array}{r}1,400 \\
0 \\
0 \\
11,292 \\
4\end{array}$ & $\begin{array}{r}1,197 \\
0 \\
0 \\
13,799 \\
5\end{array}$ & $\begin{array}{r}1,300 \\
196 \\
3 \\
7,162 \\
61\end{array}$ & $\begin{array}{r}545 \\
3 \\
36 \\
27 \\
69\end{array}$ & $\begin{array}{r}594 \\
1 \\
3 \\
641 \\
24\end{array}$ & $\begin{array}{r}797 \\
162 \\
10 \\
6,755 \\
77\end{array}$ & $\begin{array}{r}1,319 \\
27 \\
3 \\
4,233 \\
45\end{array}$ & $\begin{array}{r}509 \\
6 \\
25 \\
6,288 \\
14\end{array}$ & $\begin{array}{r}1,011 \\
5 \\
4 \\
4,353 \\
23\end{array}$ \\
\hline $\begin{array}{l}\text { Stenacron } \frac{\text { Interpunctatum }}{\text { Stenonema }} \text { terminatum } \\
\text { Brachycentrus occ1dentalis } \\
\text { Glossosoma Intermedium } \\
\text { Cheumatopsyche spp. }\end{array}$ & $\begin{array}{r}36 \\
0 \\
181 \\
0 \\
19\end{array}$ & $\begin{array}{r}1 \\
0 \\
2,041 \\
82 \\
122\end{array}$ & $\begin{array}{r}0 \\
2 \\
2,657 \\
87 \\
29\end{array}$ & $\begin{array}{r}2 \\
0 \\
402 \\
2 \\
7\end{array}$ & $\begin{array}{r}53 \\
11 \\
502 \\
1 \\
32\end{array}$ & $\begin{array}{r}21 \\
17 \\
262 \\
0 \\
7\end{array}$ & $\begin{array}{r}16 \\
8 \\
448 \\
4 \\
52\end{array}$ & $\begin{array}{r}6 \\
2 \\
13 \\
9 \\
16\end{array}$ & $\begin{array}{r}5 \\
3 \\
1,512 \\
31 \\
31\end{array}$ & $\begin{array}{r}11 \\
7 \\
1,919 \\
49 \\
42\end{array}$ & $\begin{array}{r}87 \\
16 \\
2,489 \\
82 \\
114\end{array}$ & $\begin{array}{r}15 \\
5 \\
483 \\
34 \\
51\end{array}$ & $\begin{array}{r}6 \\
6 \\
2,293 \\
66 \\
57\end{array}$ & $\begin{array}{r}68 \\
10 \\
1,559 \\
17 \\
22\end{array}$ & $\begin{array}{r}20 \\
7 \\
1,598 \\
54 \\
73\end{array}$ \\
\hline $\begin{array}{l}\frac{\text { Hydropsyche }}{\text { Symphitopsyche }} \frac{\text { betten } 1}{\text { bifida group }} \\
\text { Symphitopsyche } \\
\text { Symphitopsyche } \\
\text { Slossonae } \\
\text { Hellchus striatus }\end{array}$ & $\begin{array}{r}328 \\
0 \\
17 \\
143 \\
20\end{array}$ & $\begin{array}{r}13 \\
8 \\
591 \\
91 \\
5\end{array}$ & $\begin{array}{r}7 \\
1 \\
83 \\
32 \\
2\end{array}$ & $\begin{array}{r}11 \\
0 \\
135 \\
44 \\
12\end{array}$ & $\begin{array}{r}53 \\
3 \\
334 \\
319 \\
7\end{array}$ & $\begin{array}{r}26 \\
6 \\
55 \\
237 \\
1\end{array}$ & $\begin{array}{r}100 \\
4 \\
84 \\
180 \\
4\end{array}$ & $\begin{array}{r}44 \\
2 \\
267 \\
130 \\
4\end{array}$ & $\begin{array}{r}214 \\
1 \\
248 \\
61 \\
14\end{array}$ & $\begin{array}{r}49 \\
3 \\
264 \\
256 \\
14\end{array}$ & $\begin{array}{r}106 \\
11 \\
415 \\
374 \\
14\end{array}$ & $\begin{array}{r}114 \\
4 \\
449 \\
258 \\
3\end{array}$ & $\begin{array}{r}88 \\
4 \\
384 \\
211 \\
10\end{array}$ & $\begin{array}{r}81 \\
7 \\
181 \\
50 \\
26\end{array}$ & $\begin{array}{r}130 \\
2 \\
180 \\
302 \\
7\end{array}$ \\
\hline $\begin{array}{l}\text { Optioservus } \\
\frac{\text { fastiditus }}{\text { Stenelmis }} \text { 年enata } \\
\text { Simulium } \frac{\text { tuberosum }}{\text { Simulium }} \frac{\text { verecundum }}{\text { Simulium }} \\
\text { vittatum }\end{array}$ & $\begin{array}{r}739 \\
299 \\
178 \\
5 \\
40\end{array}$ & $\begin{array}{r}729 \\
177 \\
304 \\
1 \\
216\end{array}$ & $\begin{array}{r}376 \\
9 \\
67 \\
3 \\
119\end{array}$ & $\begin{array}{r}381 \\
42 \\
48 \\
1 \\
79\end{array}$ & $\begin{array}{r}522 \\
198 \\
166 \\
4 \\
105\end{array}$ & $\begin{array}{r}190 \\
18 \\
33 \\
24 \\
132\end{array}$ & $\begin{array}{r}548 \\
132 \\
0 \\
0 \\
188\end{array}$ & $\begin{array}{r}385 \\
124 \\
89 \\
0 \\
20\end{array}$ & $\begin{array}{r}748 \\
305 \\
304 \\
16 \\
346\end{array}$ & $\begin{array}{r}825 \\
204 \\
344 \\
18 \\
221\end{array}$ & $\begin{array}{r}842 \\
77 \\
59 \\
4 \\
57\end{array}$ & $\begin{array}{r}535 \\
181 \\
197 \\
1 \\
38\end{array}$ & $\begin{array}{r}662 \\
162 \\
337 \\
14 \\
217\end{array}$ & $\begin{array}{r}1,172 \\
232 \\
137 \\
21 \\
156\end{array}$ & $\begin{array}{r}431 \\
135 \\
125 \\
2 \\
233\end{array}$ \\
\hline $\begin{array}{l}\text { Atherix variegata } \\
\text { Chrysops spp. } \\
\text { Dicranota spp. } \\
\text { Tipula spp. } \\
\text { Cricotopus spp. }\end{array}$ & $\begin{array}{r}62 \\
0 \\
8 \\
78 \\
1\end{array}$ & $\begin{array}{r}34 \\
11 \\
113 \\
41 \\
7\end{array}$ & $\begin{array}{l}7 \\
32 \\
68 \\
21 \\
37\end{array}$ & $\begin{array}{r}48 \\
4 \\
15 \\
15 \\
0\end{array}$ & $\begin{array}{r}151 \\
1 \\
8 \\
14 \\
3\end{array}$ & $\begin{array}{r}74 \\
5 \\
2 \\
10 \\
5\end{array}$ & $\begin{array}{r}228 \\
12 \\
108 \\
128 \\
0\end{array}$ & $\begin{array}{r}58 \\
7 \\
0 \\
55 \\
0\end{array}$ & $\begin{array}{r}9 \\
6 \\
92 \\
25 \\
48\end{array}$ & $\begin{array}{r}148 \\
15 \\
69 \\
13 \\
5\end{array}$ & $\begin{array}{r}104 \\
22 \\
26 \\
54 \\
0\end{array}$ & $\begin{array}{r}118 \\
12 \\
10 \\
50 \\
9\end{array}$ & $\begin{array}{r}83 \\
6 \\
122 \\
29 \\
40\end{array}$ & $\begin{array}{r}91 \\
25 \\
8 \\
32 \\
2\end{array}$ & $\begin{array}{r}27 \\
7 \\
47 \\
36 \\
2\end{array}$ \\
\hline $\begin{array}{l}\text { Diamesa spp. } \\
\text { Eukiefferiella spp. } \\
\text { Orthocladius spp. } \\
\text { Gammarus pseudolimneus } \\
\text { Asellus intermedius }\end{array}$ & $\begin{array}{r}99 \\
1 \\
8 \\
2,347 \\
194\end{array}$ & $\begin{array}{r}29 \\
10 \\
5 \\
712 \\
0\end{array}$ & $\begin{array}{r}13 \\
9 \\
12 \\
1,635 \\
0\end{array}$ & $\begin{array}{r}9 \\
4 \\
4 \\
697 \\
0\end{array}$ & $\begin{array}{r}5 \\
8 \\
0 \\
193 \\
27\end{array}$ & $\begin{array}{r}18 \\
2 \\
0 \\
317 \\
6\end{array}$ & $\begin{array}{r}32 \\
0 \\
4 \\
2,644 \\
44\end{array}$ & $\begin{array}{r}73 \\
15 \\
13 \\
1,275 \\
25\end{array}$ & $\begin{array}{r}68 \\
13 \\
12 \\
890 \\
57\end{array}$ & $\begin{array}{r}16 \\
2 \\
0 \\
1,327 \\
76\end{array}$ & $\begin{array}{r}8 \\
4 \\
3 \\
1,748 \\
58\end{array}$ & $\begin{array}{r}14 \\
5 \\
0 \\
1,530 \\
24\end{array}$ & $\begin{array}{r}15 \\
11 \\
12 \\
1,467 \\
25\end{array}$ & $\begin{array}{r}31 \\
5 \\
9 \\
1,107 \\
35\end{array}$ & $\begin{array}{r}105 \\
13 \\
7 \\
1,136 \\
132\end{array}$ \\
\hline
\end{tabular}




\title{
Reproduction of Brown Trout
}

\author{
By Eddie L. Avery ${ }^{1}$
}

\section{INTRODUCTION}

This study was initiated to determine the influence of the Trout Creek floodwater-retarding structure (FRS) on the spawning environment and embryo survival of wild brown trout (Salmo trutta). Data were collected during three reproductive seasons--fall and winter 1975-76, 1976-77, and 1977-78. The procedures and results summarized in this section are presented in greater detail by Avery (1980).

Special credit is given Robert F. Carline, who was in charge of this study during the first year. Oscar Brynildson provided background information relating to Trout Creek, and this provided impetus for the study. Appreciation also is extended to Kent Niermeyer and Harrison Sheldon, who assisted in the fieldwork.

Funding was provided by the U.S. Soil Conservation Service, under contract number AG-55SCS00159, and by the Federal Aid in Fish Restoration Act, under Dingell-Johnson Project F-83-R.

\section{DESCRIPTION OF THE STUDY AREA}

Although the entire stream below Birch Lake is classified as trout water, natural reproduction occurs primarily in the 3.4-mi reach between Arndt Spring and the second downstream intersection of the stream with County Highway T (fig. 32). This reach is Class $I^{2}$ trout water and constitutes the study area. The FRS approximately bisects the study area.

\section{METHODS}

Numbered metal fenceposts designating 300-yd stream stations (fig. 32) were present on Trout Creek when the study began in October 1975 (see O. M. Brynildson, "Trout Populations"). The stream was walked during each reproductive season to determine the number and location of trout redds relative to these stations. Only one redd count was made during 1975-76. Bimonthly redd counts were made during the 1976-77 and $1977-78$ reproductive seasons to provide better estimates of the total number of redds.

Substrate samples were collected from redds during the 1975-76 reproductive season to determine substrate composition immediately following egg deposition, during egg development, and near the time of fry emergence. A substrate sampler similar to that described by McNeil and Ahnell (1964) was used. Samples were dried and sifted through seven standard soil sieves with mesh sizes ranging from 0.106 to $8.0 \mathrm{~mm}$. Each fraction was weighed and converted to a percentage of the total weight.

During the 1975-76 and 1976-77 reproductive seasons, intragravel dissolved-oxygen concentrations were monitored on study redds upstream and downstream from the FRS by procedures similar to those described by McNeil (1962). Two or three plastic standpipes with holes in the bottom 3 in. were driven into each redd. Sediment and turbid water were evacuated orally using a piece of flexible plastic tubing. Water samples were analyzed for dissolved-oxygen concentration using Harper's (1953) semimicro modification of the Winkler method.

\footnotetext{
${ }^{1}$ Wisconsin Department of Natural Resources, Bureau of Research, Route 1, Box 589, Waupaca, Wisconsin 54981.

${ }^{2}$ Class I--High-grade trout waters with good year-round stream temperatures and sufficient natural reproduction to fill the available habitat. Little or no stocking of hatchery trout is necessary.
} 


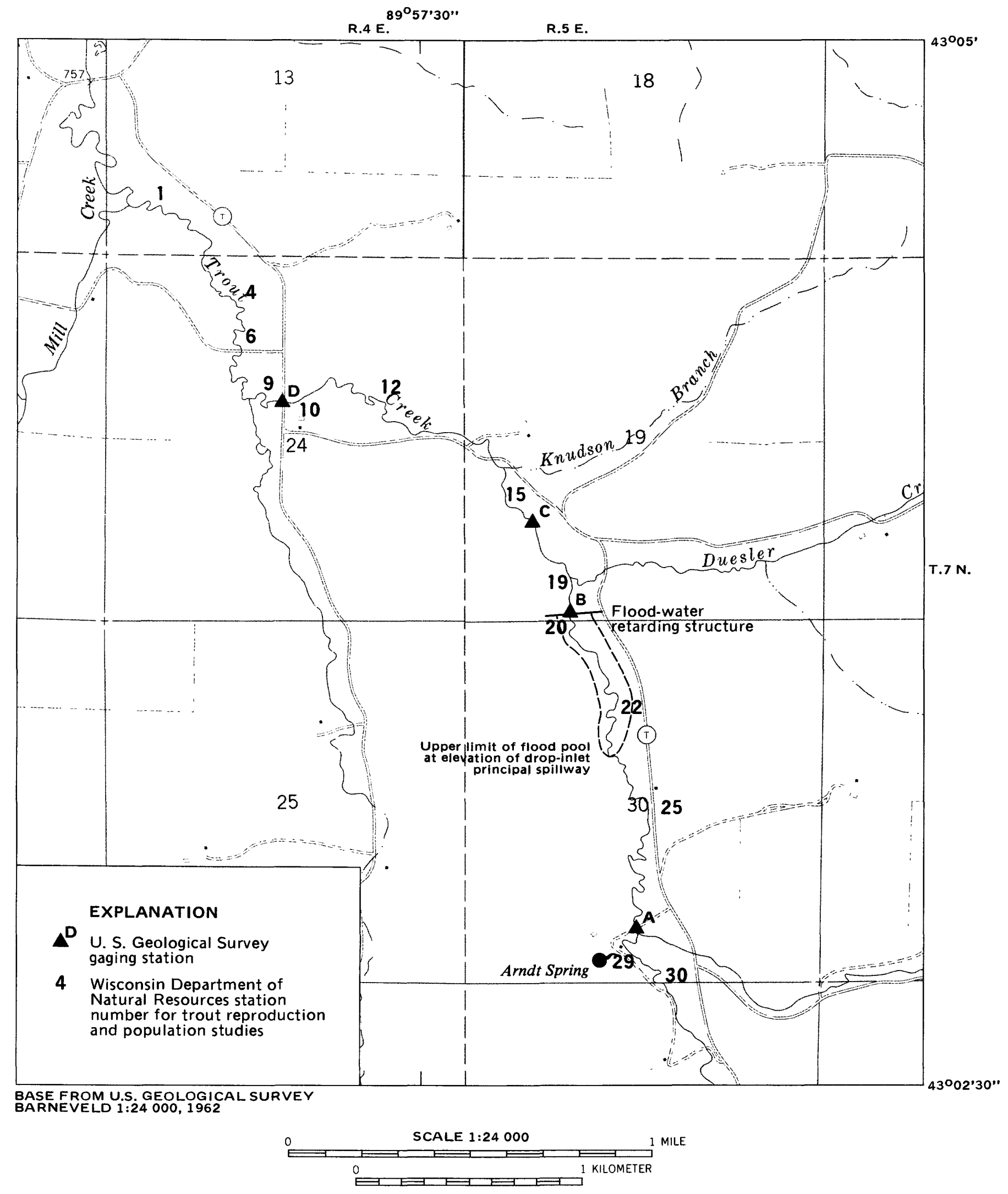

Figure 32. Locations of stations used in the trout reproduction and population studies. 
Intragravel water temperatures were measured in redds upstream and downstream from the FRS during the 1975-76 and 1976-77 reproductive seasons using a soil probe equipped with a thermistor; stream temperatures were measured with a handheld thermometer. Stream temperatures also were recorded continuously from November 1975 to February 1976 using submersible thermographs at stations 10 and 21. Also, stream temperatures were recorded continuously at sites A, C, and D (fig. 32) from August 1976 to September 1979. These data have been published by the U.S. Geological Survey $(1978,1979,1980)$.

Stream depth and current velocity over study redds upstream and downstream from the FRS were measured during the $1975-76$ and $1976-77$ reproductive seasons.

Redds upstream and downstream from the FRS were partly excavated in December 1975 and 1976 and also during January-March 1976, 1977, and 1978 to determine embryo survival and stage of development. Redds were excavated on March 2, 1977 , specifically to determine the effects of flooding in late February on embryo survival.

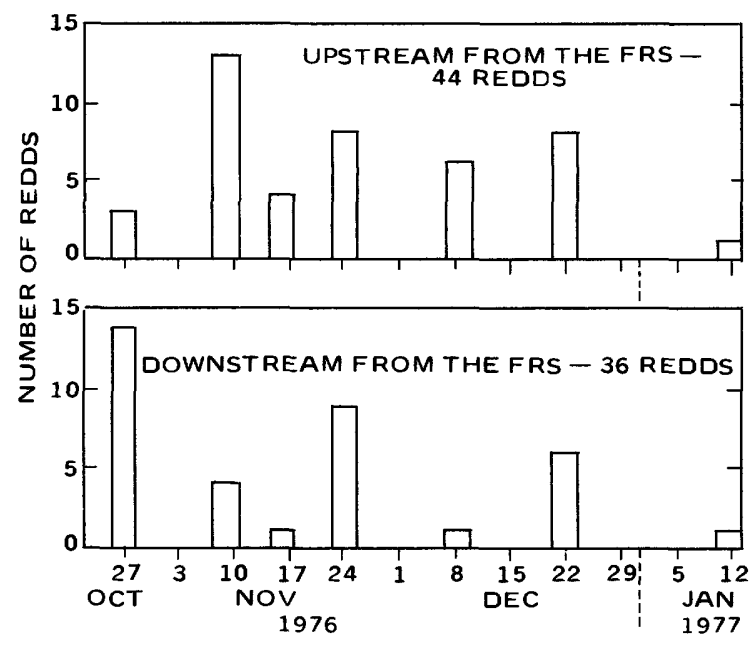

Figure 33. Chronology of redd construction by brown trout, 1976-77.

\section{RESULTS AND DISCUSSION}

\section{Enumeration of Trout Redds}

Eight to nine redds downstream and 31 to 37 redds upstream from the FRS were located during the 1975-76 reproductive season. Thirty-six redds downstream and 44 redds upstream from the FRS were located during the 1976-77 reproductive season. Fifty redds downstream and 118 redds upstream from the FRS were located during the 1977-78 reproductive seasons. No redds were found in the first 300-yd station (number 20) upstream from the FRS during the study.

The chronology of redd counts in the fall of 1976 (fig. 33) shows that spawning downstream from the FRS began 1 to 2 weeks earlier than upstream. This was also true during the fall of 1977 (fig. 34).

\section{Stream Temperature}

Stream-temperature data indicate that most ground water probably discharges at stations 30 and

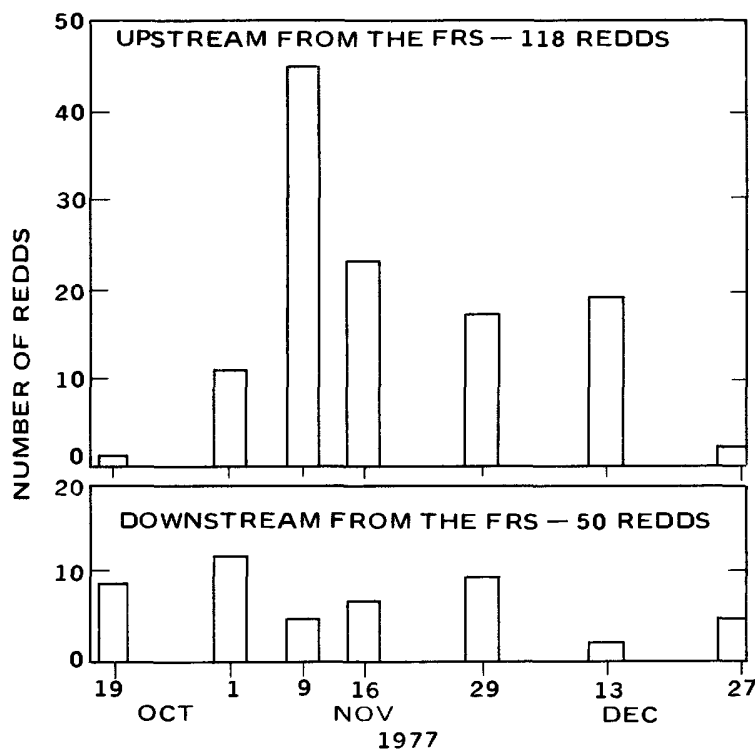

Figure 34. Chronology of redd construction by brown trout, fall 1977. 
29 near Arndt Spring (fig. 32). Some discharge occurs between stations 28 and 21 , but downstream from the FRS little ground-water discharge is evident. (See also D. J. Graczyk, S. J. Field, and D. A. Wentz, "Streamflow, Sedimentation Processes, and Channel Morphology").

Weekly mean water temperatures upstream from the FRS at station 21 were $0.4^{\circ}$ to $3.1^{\circ} \mathrm{C}$ higher than corresponding temperatures downstream at station 10 throughout the winter of 1975-76 (table 17). Weekly mean stream temperatures during the winter of 1976-77 also were higher upstream from the FRS (fig. 35). Weekly mean temperatures at station 29, upstream from the FRS, ranged from $5.0^{\circ}$ to $6.7^{\circ} \mathrm{C}$ from early November through mid-February, while at stations 17 and 10 , downstream, corresponding temperatures ranged from $0^{\circ}$ to $4.4^{\circ} \mathrm{C}$. During three weeks in January 1977 , weekly mean stream temperatures at station
10 ranged from $0.2^{\circ}$ to $0.7^{\circ} \mathrm{C}$. The stream froze, and 1 to 3 in. of anchor ice covered the streambed as far upstream as station 12.

\section{Substrate Composition, Water Depth, and Current Velocity}

Fine materials in trout redds reduce their permeability. Low permeability, in turn, inhibits both influx of fresh oxygenated water to buried eggs and the removal of metabolic wastes. Changes in the percentage composition of fine particles $(<1$ $\mathrm{mm}$ diameter) in trout redds were inconsistent during the egg incubation period of 1975-76 (table 18). There were no marked differences in the percentages of fine materials in redds upstream and downstream from the FRS (table 18), and there was no detectable relationship between water depth or current velocity over the redds and substrate composition.

Table 17. Weekly mean stream temperatures at station 10 , downstream from the floodwaterretarding structure (FRS), and at station 21, upstream from the FRS.

\begin{tabular}{|c|c|c|}
\hline \multirow[b]{2}{*}{ Week of } & \multicolumn{2}{|c|}{ Stream temperature, $\left({ }^{\circ} \mathrm{C}\right)$} \\
\hline & Station $10^{1}$ & Station $21^{1}$ \\
\hline \multicolumn{3}{|l|}{1975} \\
\hline $\begin{array}{ll}\text { November } & 9 \\
\text { November } & 16 \\
\text { November } & 23 \\
\text { November } & 30\end{array}$ & $\begin{array}{l}5.1 \\
6.8 \\
2.6 \\
3.4\end{array}$ & $\begin{array}{l}6.0 \\
7.4 \\
3.3 \\
3.8\end{array}$ \\
\hline $\begin{array}{ll}\text { December } & 7 \\
\text { December } & 14 \\
\text { December } & 21 \\
\text { December } & 28\end{array}$ & $\begin{array}{l}3.9 \\
3.1 \\
3.5 \\
3.7\end{array}$ & $\begin{array}{l}4.8 \\
5.3 \\
4.6 \\
4.7\end{array}$ \\
\hline \multicolumn{3}{|l|}{1976} \\
\hline $\begin{array}{ll}\text { January } & 4 \\
\text { January } & 11 \\
\text { January } & 18 \\
\text { January } & 25\end{array}$ & $\begin{array}{l}.7 \\
2.1 \\
2.5 \\
2.9\end{array}$ & $\begin{array}{l}3.8 \\
--- \\
--\end{array}$ \\
\hline February 1 & 1.9 & -- \\
\hline
\end{tabular}

${ }^{1}$ See figure 32 for locations. 
Table 18. Water depths and current velocities over trout redds and percent, by weight, of redd substrates downstream and upstream from the floodwater-retarding structure (FRS), 1975-76.

\begin{tabular}{|c|c|c|c|c|}
\hline Station ${ }^{1}$ & Month & $\begin{array}{c}\text { Current velocity } \\
\text { over redd } \\
(\mathrm{ft} / \mathrm{s})\end{array}$ & $\begin{array}{l}\text { Water depth } \\
\text { over redd } \\
\text { (ft) }\end{array}$ & $\begin{array}{l}\text { Percent, by weight } \\
\text { of redd substrate } \\
(<1.0 \mathrm{~mm})\end{array}$ \\
\hline \multicolumn{5}{|c|}{$\begin{array}{c}\text { Downstream } \\
\text { from FRS } \\
\end{array}$} \\
\hline $\begin{array}{l}10 \\
10 \\
10\end{array}$ & $\begin{array}{l}\text { November } \\
\text { January } \\
\text { February }\end{array}$ & 1.37 & 0.50 & $\begin{array}{r}4.9 \\
27.4 \\
15.7\end{array}$ \\
\hline $\begin{array}{l}13 \\
13 \\
13\end{array}$ & $\begin{array}{l}\text { November } \\
\text { January } \\
\text { February }\end{array}$ & 1.70 & $\cdots$ & $\begin{array}{l}---- \\
23.2 \\
25.4\end{array}$ \\
\hline $\begin{array}{l}15 \\
15 \\
15\end{array}$ & $\begin{array}{l}\text { November } \\
\text { January } \\
\text { February }\end{array}$ & 1.23 & .50 & $\begin{array}{l}35.4 \\
23.5 \\
28.6\end{array}$ \\
\hline $\begin{array}{l}18 \\
18 \\
18\end{array}$ & $\begin{array}{l}\text { November } \\
\text { January } \\
\text { February }\end{array}$ & 2.50 & .55 & $\begin{array}{l}31.5 \\
22.1 \\
26.6\end{array}$ \\
\hline $\begin{array}{l}19 \\
19 \\
19\end{array}$ & $\begin{array}{l}\text { November } \\
\text { January } \\
\text { February }\end{array}$ & 2.48 & .45 & $\begin{array}{l}23.7 \\
25.6 \\
18.2\end{array}$ \\
\hline \multicolumn{5}{|l|}{$\begin{array}{l}\text { Upstream } \\
\text { from FRS } \\
\end{array}$} \\
\hline $\begin{array}{l}21 \\
21 \\
21\end{array}$ & $\begin{array}{l}\text { November } \\
\text { January } \\
\text { February }\end{array}$ & 2.10 & .45 & $\begin{array}{r}11.0 \\
9.4 \\
12.8\end{array}$ \\
\hline $\begin{array}{l}24 \\
24 \\
24\end{array}$ & $\begin{array}{l}\text { November } \\
\text { January } \\
\text { February }\end{array}$ & 1.65 & 1.20 & $\begin{array}{l}19.1 \\
25.7 \\
26.2\end{array}$ \\
\hline $\begin{array}{l}24 \\
24 \\
24\end{array}$ & $\begin{array}{l}\text { November } \\
\text { January } \\
\text { February }\end{array}$ & 1.48 & 1.50 & $\begin{array}{l}57.0 \\
16.9 \\
26.7\end{array}$ \\
\hline $\begin{array}{l}26 \\
26 \\
26\end{array}$ & $\begin{array}{l}\text { November } \\
\text { January } \\
\text { February }\end{array}$ & 2.50 & $-\infty$ & $\begin{array}{l}15.3 \\
24.6 \\
24.9\end{array}$ \\
\hline $\begin{array}{l}27 \\
27 \\
27\end{array}$ & $\begin{array}{l}\text { November } \\
\text { January } \\
\text { February }\end{array}$ & 2.50 & $-\infty$ & $\begin{array}{l}11.0 \\
19.7 \\
34.7\end{array}$ \\
\hline
\end{tabular}

${ }^{1}$ See figure 32 for locations.

¿ Two redds were sampled at station 24. 
Table 19. Water depths and current velocities over trout redds downstream and upstream from the floodwater-retarding structure (FRS), 1976-77.

\begin{tabular}{|c|c|c|c|}
\hline Station 1 & Date & $\begin{array}{l}\text { Depth } \\
\text { (in.) }\end{array}$ & $\begin{array}{l}\text { Velocity } \\
(\mathrm{ft} / \mathrm{s})\end{array}$ \\
\hline \multicolumn{4}{|c|}{$\begin{array}{l}\text { Downstream } \\
\text { from FRS }\end{array}$} \\
\hline 10 & $\begin{array}{lr}\text { Nov. } 24,1976 \\
\text { Feb. } 9,1977\end{array}$ & $\begin{array}{r}0.50 \\
.45\end{array}$ & $\begin{array}{l}1.58 \\
1.58\end{array}$ \\
\hline 13 & $\begin{array}{lll}\text { Nov. } & 9,1976 \\
\text { Feb. } & 9,1977\end{array}$ & $\begin{array}{l}.60 \\
.55\end{array}$ & $\begin{array}{r}1.78 \\
.82\end{array}$ \\
\hline 13 & $\begin{array}{lr}\text { Nov. } 24,1976 \\
\text { Feb. } 9,1977\end{array}$ & $\begin{array}{l}.40 \\
.50\end{array}$ & $\begin{array}{l}1.49 \\
1.35\end{array}$ \\
\hline 15 & $\begin{array}{lr}\text { Nov. } 24,1976 \\
\text { Feb. } 9,1977\end{array}$ & $\begin{array}{l}.50 \\
.55\end{array}$ & $\begin{array}{l}1.41 \\
1.55\end{array}$ \\
\hline 19 & 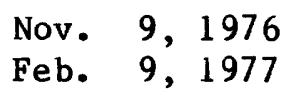 & $\begin{array}{l}.60 \\
.50\end{array}$ & $\begin{array}{l}2.17 \\
2.22\end{array}$ \\
\hline \multicolumn{4}{|l|}{$\begin{array}{l}\text { Upstream } \\
\text { from FRS } \\
\end{array}$} \\
\hline 22 & $\begin{array}{lll}\text { Nov. } & 9, & 1976 \\
\text { Feb. } & 9, & 1977\end{array}$ & $\begin{array}{l}.90 \\
.75\end{array}$ & $\begin{array}{r}1.71 \\
.84\end{array}$ \\
\hline 25 & $\begin{array}{lll}\text { Nov. } & 9, & 1976 \\
\text { Feb. } & 9, & 1977\end{array}$ & $\begin{array}{l}.60 \\
.70\end{array}$ & $\begin{array}{l}2.17 \\
1.17\end{array}$ \\
\hline 27 & $\begin{array}{lr}\text { Nov. } & 24,1976 \\
\text { Feb. } & 9,1977\end{array}$ & $\begin{array}{l}.85 \\
.55\end{array}$ & $\begin{array}{l}1.61 \\
1.24\end{array}$ \\
\hline 28 & $\begin{array}{lll}\text { Nov. } & 9,1976 \\
\text { Feb. } & 9, & 1977\end{array}$ & $\begin{array}{l}.55 \\
.35\end{array}$ & $\begin{array}{r}1.52 \\
.52\end{array}$ \\
\hline
\end{tabular}

${ }^{1}$ See figure 32 for locations.

${ }^{2}$ Two redds were sampled at station 13 . 


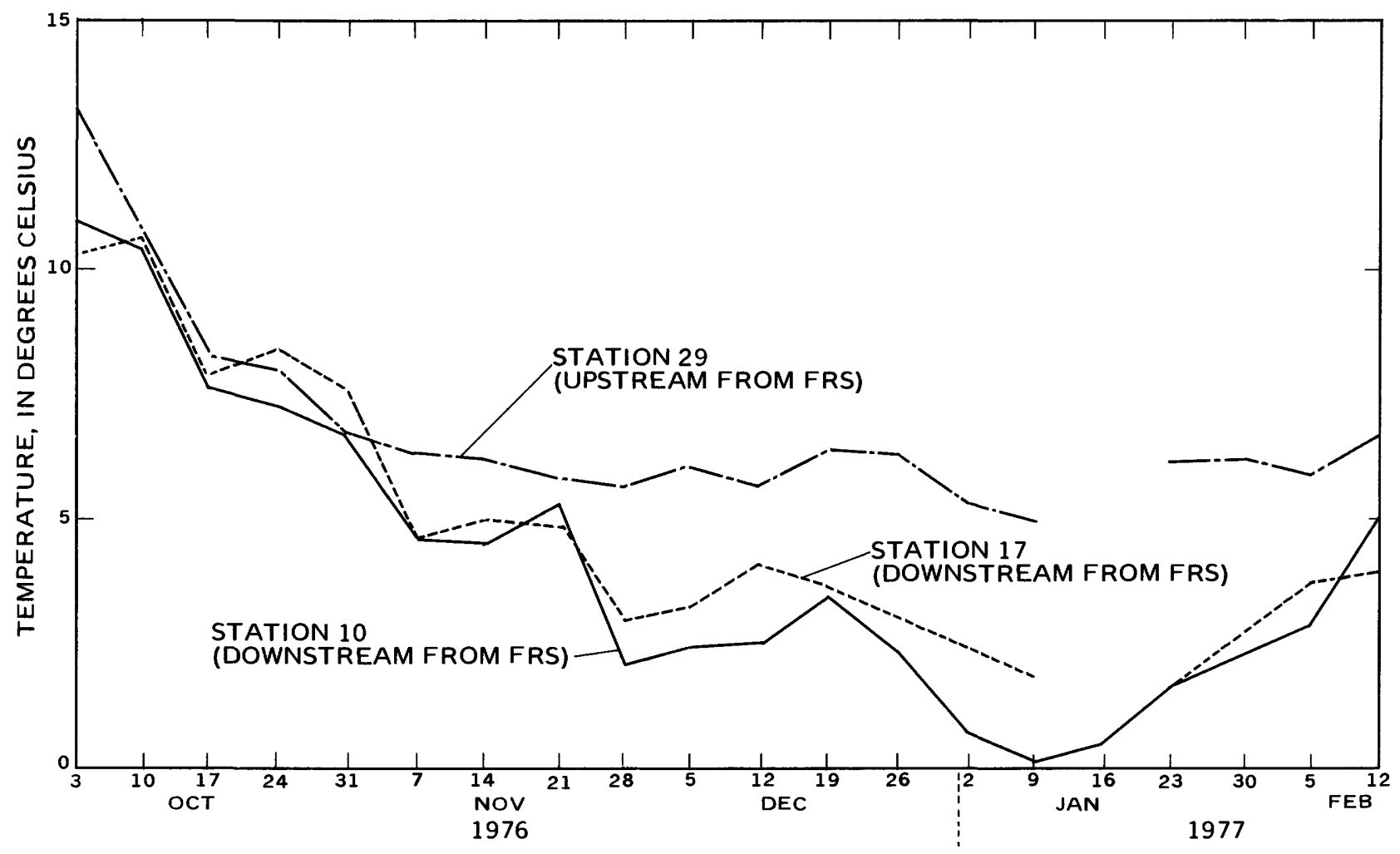

Figure 35. Weekly mean stream temperatures upstream and downstream from the floodwater-retarding structure (FRS) during the fall 1976-77 reproductive season.

During the 1976-77 egg-incubation period, both depth and velocity of water over redds in Trout Creek showed a general decline (table 19). Over six of nine redds, decreases in stream depths ranged from 0.05 to $0.3 \mathrm{ft}$. Increases in stream depth ranged from 0.05 to $0.1 \mathrm{ft}$ over three redds. Declines in stream velocity ranged from 0.37 to $1.0 \mathrm{ft} / \mathrm{s}$ over six of nine redds, whereas velocity was stable over one and increased 0.05 to $0.14 \mathrm{ft} / \mathrm{s}$ over the other two redds.

Declines in stream depth and current velocity over trout redds were more apparent upstream from the FRS during the 1976-77 reproductive season (table 19). Water depths declined over three of the four redds monitored, while stream velocity declined over all four redds. This is consistent with the observed prevalence of more aquatic vegetation, primarily watercress, upstream from the FRS; this vegetation tended to constrict and braid the stream into deep narrow channels with high current velocities. Winter die off of the watercress allowed stream depths and current velocities to decrease.

\section{Intragravel Dissolved-Oxygen Concentrations}

Intragravel concentrations of dissolved oxygen differed considerably within and between trout redds during the 1975-76 reproductive season (table 20 ). Based on other studies of the effects of dissolved oxygen upon egg survival of salmon species (Alderdice and others, 1958; Coble, 1961; Silver and others, 1963), $5.0 \mathrm{mg} / \mathrm{L}$ is an approximate concentration above which reasonable survival of trout embryos can be expected. Mean intragravel dissolved-oxygen concentrations were less than 5.0 $\mathrm{mg} / \mathrm{L}$ in two of five redds downstream from the FRS and in two of five redds upstream from the 
Table 20. Intragravel dissolved-oxygen concentrations in trout redds downstream and upstream from the floodwater-retarding structure (FRS), 1975-76.

\begin{tabular}{|c|c|c|c|c|c|c|}
\hline \multirow[b]{2}{*}{ Station ${ }^{2}$} & \multicolumn{6}{|c|}{ Dissolved-oxygen concentration (mg/L) } \\
\hline & Dec. 11 & Dec. 23 & Jan. 22 & Feb. 13 & Mean & Variance \\
\hline \multicolumn{7}{|c|}{$\begin{array}{l}\text { Downstream } \\
\text { from FRS }\end{array}$} \\
\hline 10 & $\frac{0.3}{.6}$ & $\begin{array}{l}\frac{3.2}{9.7} \\
-\end{array}$ & $\begin{array}{l}7.2 \\
8.4 \\
---\end{array}$ & -- & $\underline{4.34}$ & 15.9 \\
\hline 13 & $\begin{array}{l}6.6 \\
7.3\end{array}$ & $\begin{array}{l}5.1 \\
8.2\end{array}$ & $\begin{array}{l}9.9 \\
9.6\end{array}$ & $\begin{array}{l}7.2 \\
9.2\end{array}$ & 7.88 & 2.76 \\
\hline 15 & $\frac{4.5}{2.6}$ & $\begin{array}{l}6.1 \\
4.2 \\
\end{array}$ & $\begin{array}{l}9.2 \\
5.1\end{array}$ & $\frac{2.3}{4.7}$ & $\underline{4.84}$ & 4.75 \\
\hline 18 & $\begin{array}{l}7.1 \\
7.7\end{array}$ & $\frac{4.8}{6.4}$ & $\frac{3.8}{---}$ & $\frac{2.4}{---}$ & 5.66 & 4.00 \\
\hline 19 & $\begin{array}{l}8.5 \\
8.9\end{array}$ & $\begin{array}{r}7.3 \\
10.3\end{array}$ & $\begin{array}{l}7.8 \\
---\end{array}$ & $\frac{3.4}{3.8}$ & 7.16 & 6.66 \\
\hline \multicolumn{7}{|l|}{$\begin{array}{l}\text { Upstream } \\
\text { from FRS }^{3}\end{array}$} \\
\hline 21 & $\begin{array}{l}7.0 \\
6.1\end{array}$ & $\begin{array}{l}5.8 \\
---\end{array}$ & $\begin{array}{r}9.6 \\
10.6\end{array}$ & $\begin{array}{l}7.2 \\
7.9\end{array}$ & 7.64 & 6.97 \\
\hline 24 & $\begin{array}{l}\frac{3.4}{5.2} \\
6.4\end{array}$ & $\begin{array}{l}6.3 \\
1.2 \\
--\end{array}$ & $\begin{array}{l}8.0 \\
---\end{array}$ & $\frac{3.7}{---}$ & 4.86 & 5.26 \\
\hline 24 & -- & $\begin{array}{l}5.0 \\
4.0 \\
\end{array}$ & $\begin{array}{l}7.8 \\
6.3\end{array}$ & $\begin{array}{l}7.5 \\
6.4\end{array}$ & 6.16 & 2.12 \\
\hline 26 & $\begin{array}{l}\frac{1.3}{7.3} \\
5.6\end{array}$ & $\begin{array}{l}6.7 \\
4.1 \\
-\end{array}$ & $\begin{array}{l}5.8 \\
4.4 \\
--\end{array}$ & $\begin{array}{l}6.8 \\
1.7 \\
--\end{array}$ & $\underline{4.87}$ & 4.69 \\
\hline 27 & $\begin{array}{l}6.1 \\
6.6\end{array}$ & $\begin{array}{l}5.8 \\
4.7 \\
\end{array}$ & $\begin{array}{l}9.9 \\
9.1\end{array}$ & $\begin{array}{l}5.1 \\
7.6\end{array}$ & 6.84 & 3.46 \\
\hline
\end{tabular}

${ }^{1}$ Concentrations less than $5.0 \mathrm{mg} / \mathrm{L}$ are underlined; data for November were not considered because of sampling problems.

${ }^{2}$ See figure 32 for locations.

${ }^{3}$ Two redds were sampled at station 24 . 
Table 21. Intragravel dissolved-oxygen concentrations in trout redds downstream and upstream from the floodwater-retarding structure (FRS), 1976-77.

Dissolved-oxygen concentration ( $\mathrm{mg} / \mathrm{L}$ )

\begin{tabular}{|c|c|c|c|c|c|c|c|c|}
\hline Station ${ }^{2}$ & Nov. 9 & Nov. 23 & Dec. 8 & Dec. 22 & Jan. 12 & Jan. 26 & Feb. 8 & Mean \\
\hline \multicolumn{9}{|c|}{$\begin{array}{l}\text { Downstream } \\
\text { from FRS }^{3}\end{array}$} \\
\hline 10 & $\begin{array}{r}9.4 \\
10.3\end{array}$ & $\begin{array}{r}10.4 \\
6.1\end{array}$ & $\begin{array}{l}6.5 \\
4.7 \\
\end{array}$ & $\begin{array}{r}10.3 \\
.8 \\
\end{array}$ & $\begin{array}{l}\mathrm{F}^{4} \\
\mathrm{~F}^{4}\end{array}$ & $\frac{3.4}{4.2}$ & $\begin{array}{l}9.1 \\
1.5 \\
\end{array}$ & 5.55 \\
\hline 10 & $\begin{array}{l}9.5 \\
9.0 \\
---\end{array}$ & $\begin{array}{l}\frac{1.7}{11.0} \\
10.9\end{array}$ & $\begin{array}{r}7.0 \\
10.4 \\
9.1\end{array}$ & $\begin{array}{l}\frac{.2}{9.1} \\
6.7\end{array}$ & $\begin{array}{l}\mathrm{F}^{4} \\
\mathrm{~F}^{4} \\
\mathrm{~F}^{4}\end{array}$ & $\frac{.9}{.9}$ & $\overline{--}$ & 5.52 \\
\hline 13 & -- & $\begin{array}{l}17.4 \\
11.1\end{array}$ & $\begin{array}{r}8.9 \\
10.9\end{array}$ & $\begin{array}{l}7.7 \\
8.2\end{array}$ & $\begin{array}{l}10.8 \\
14.0\end{array}$ & $\begin{array}{l}6.2 \\
6.8\end{array}$ & $\begin{array}{l}7.0 \\
8.0\end{array}$ & 9.75 \\
\hline 13 & $\begin{array}{l}7.1 \\
8.0\end{array}$ & $\frac{1.5}{4.4}$ & $\begin{array}{r}12.6 \\
6.4\end{array}$ & $\frac{3.5}{7.2}$ & $\begin{array}{l}\mathbf{S I}^{3} \\
\mathbf{S I}^{3}\end{array}$ & $\frac{.7}{4.4}$ & $\frac{3.3}{3.1}$ & 5.18 \\
\hline 15 & -- & $\begin{array}{l}9.1 \\
6.7\end{array}$ & $\begin{array}{r}10.1 \\
8.9\end{array}$ & $\begin{array}{l}7.8 \\
8.7\end{array}$ & $\frac{2.7}{0.0}$ & $\frac{3.6}{1.1}$ & $\begin{array}{l}9.4 \\
3.6 \\
\end{array}$ & 5.98 \\
\hline 19 & $\begin{array}{l}8.3 \\
6.1\end{array}$ & $\begin{array}{l}8.5 \\
4.2 \\
\end{array}$ & $\begin{array}{l}7.3 \\
6.9\end{array}$ & $\begin{array}{l}5.9 \\
6.1\end{array}$ & $\begin{array}{r}10.5 \\
6.0\end{array}$ & $\frac{3.2}{4.1}$ & $\begin{array}{l}6.3 \\
5.7\end{array}$ & 6.36 \\
\hline
\end{tabular}

\begin{tabular}{l} 
Upstream \\
from FRS \\
\hline
\end{tabular}

21

7.47 .8

7.8

7.2

6.2

7.9

$\frac{4.8}{7.5}$

8.5

$-$

$\frac{2.0}{7.9}$

7.28

22

5.98 .3

7.8

9.5

7.2

7

$9.3 \quad 10.1$

6.9

4.9

7.7

9.8

7.1

10.0

8.06

22

$\begin{array}{ll}-- & 3.8 \\ -- & 6.4 \\ - & 3.8\end{array}$

5.9

5.2

$\frac{4.6}{5.0}$

4.2

$-$

25

7.6
8.9

9.2

$\frac{4.3}{5.2}$

5.1

4.4

4.6

$\frac{4.1}{5.5}$

$-$

$4.4 \quad 5.9$

$--$

7.1

7.1

7.7

6.6

8.5

7.62

27

$\longrightarrow$

8.5

$9.6 \quad 10.0$

7.6

9.9

5.8

6.4

4.5

7.63

28

$\begin{array}{rrrrrrrr}6.4 & 7.7 & 8.5 & 8.6 & 6.0 & 8.1 & 6.8 & \\ 7.9 & 7.7 & 8.6 & 9.2 & 7.7 & 4.3 & 9.3 & 7.99 \\ 9.1 & 7.8 & 9.8 & 10.0 & 5.9 & 9.6 & 8.9 & \end{array}$

${ }^{1}$ Concentrations less than $5.0 \mathrm{mg} / \mathrm{L}$ are underlined.

${ }^{2}$ See figure 32 for locations.

${ }^{3}$ Two redds were sampled at stations 10,13 , and 22 .

${ }^{4} \mathrm{~F}=$ stream frozen over; anchor ice present; assumed $\leq 0.5 \mathrm{mg} / \mathrm{L}$ dissolved oxygen.

${ }^{5} \mathrm{SI}=$ shelf ice over redd. 
FRS. There appeared to be little difference between intragravel dissolved-oxygen concentrations upstream and downstream from the FRS during 1975-76.

Two generalities emerged from determination of intragravel dissolved-oxygen concentrations during the 1976-77 reproductive season (table 21). On a given date, intragravel dissolved-oxygen concentrations were more consistent within individual redds upstream from the FRS than downstream from the FRS, and concentrations generally were higher in redds upstream from the FRS than downstream from the FRS.

\section{Egg Development and Survival}

Neither of two redds excavated downstream from the FRS in late December 1975 contained trout eggs. Such empty redds are known as false redds. Two of seven redds excavated upstream from the FRS were false redds, but egg survival in the remaining five redds averaged 43.6 percent.

In mid-February 1976,17 additional redds were excavated, and three were empty. Hatching of sac fry was evident in three of five redds containing eggs downstream from the FRS and in five of nine redds containing eggs upstream from the FRS. Survival of embryos ranged from 7.9 to 17.4 percent, with a mean of 12.9 percent, in four redds downstream from the FRS (table 22). A survival of 86.7 percent was noted in the fifth redd (station 13); this was the only redd with detectable ground-water discharge, as evidenced by intragravel water temperatures $4.1^{\circ} \mathrm{C}$ warmer than stream temperatures. Upstream from the FRS, embryo survival averaged 52.9 percent and ranged from 0 to 93.2 percent in the nine redds.

Egg survivals in one redd excavated upstream from the FRS and in one redd excavated downstream from the FRS in late December 1976 were 97 and 99 percent, respectively. In the upstream redd, two size groups of eggs with different pigmentation indicated that superimposition (one redd constructed on top of another by different trout) had occurred.

In January and February 1977 , six redds were excavated upstream from the FRS and six redds were excavated downstream from the FRS. Upstream from the FRS, embryo survival ranged from more than 66 to 100 percent in five redds; survival was nil in the sixth redd due to exposure of the redd following winter die off of watercress and lowered stream levels. Embryo survival was nil in three redds downstream from the FRS, and one redd did not contain any eggs (table 23). Survival was 80 and
91 percent in the other two redds. Embryos were well developed, but no live sac fry were found. From 60 to 65 percent of all redds found downstream from the FRS were located at stations 13 and 15.

Excavation of three redds upstream from the FRS and four redds downstream from the FRS were made on March 2, 1977, following heavy rains and flooding that occurred in late February. Live eggs were found in all but one redd downstream from the FRS; whereas upstream from the FRS, live sac fry were present in two of three redds. Apparently, hatching had not occurred downstream from the FRS. Floodwaters in late February had little or no adverse effect upon the survival of eggs and fry still remaining in streambed gravels.

Eggs or sac fry were present in 12 of 17 redds sampled upstream from the FRS and in 10 of 16 redds sampled downstream from the FRS in February and early March 1978 (table 24). Superimposition was noted in one of the redds downstream from the FRS, and live sac fry were found in redds both upstream and downstream from the FRS. Embryo development generally was not as far along in the redds downstream from the FRS as it was in redds upstream from the FRS. Survival of brown trout eggs during the 1977-78 reproductive season averaged 46 percent upstream from the FRS and 52 percent downstream from the FRS. There was a 91 percent increase in the number of redds upstream from the FRS compared to the 1976-77 reproductive season. Downstream from the FRS, there was a 42 percent increase in number of redds relative to 1976-77.

\section{Survival and Abiotic Factors}

Embryo survival during the $1975-76$ reproductive season was not correlated with substrate composition of redds or with water depth or current velocities over individual redds. Mean percentage, by weight, of substrate particles smaller than 1.0 $\mathrm{mm}$ are 23.1 percent for the five redds with the lowest survival (10.3 percent) and 24.9 percent for the five redds with the highest survival (60.3 percent). A significant difference in the mean values of substrate particles smaller than $1.0 \mathrm{~mm}$ was not present at the 5 percent level. Mean current velocities over the five redds with the poorest survival and the five redds with the best survival were identical at $2.0 \mathrm{ft} / \mathrm{s}$. Embryo survival also was not correlated with changes in water depth or current velocities over individual redds during the 1976-77 reproductive season.

Mean intragravel dissolved-oxygen concentrations ranged from 4.8 to $7.9 \mathrm{mg} / \mathrm{L}$ in redds moni- 
Table 22. Embryo survival in trout redds downstream and upstream from the floodwater-retarding structure (FRS), February 12, 1976.

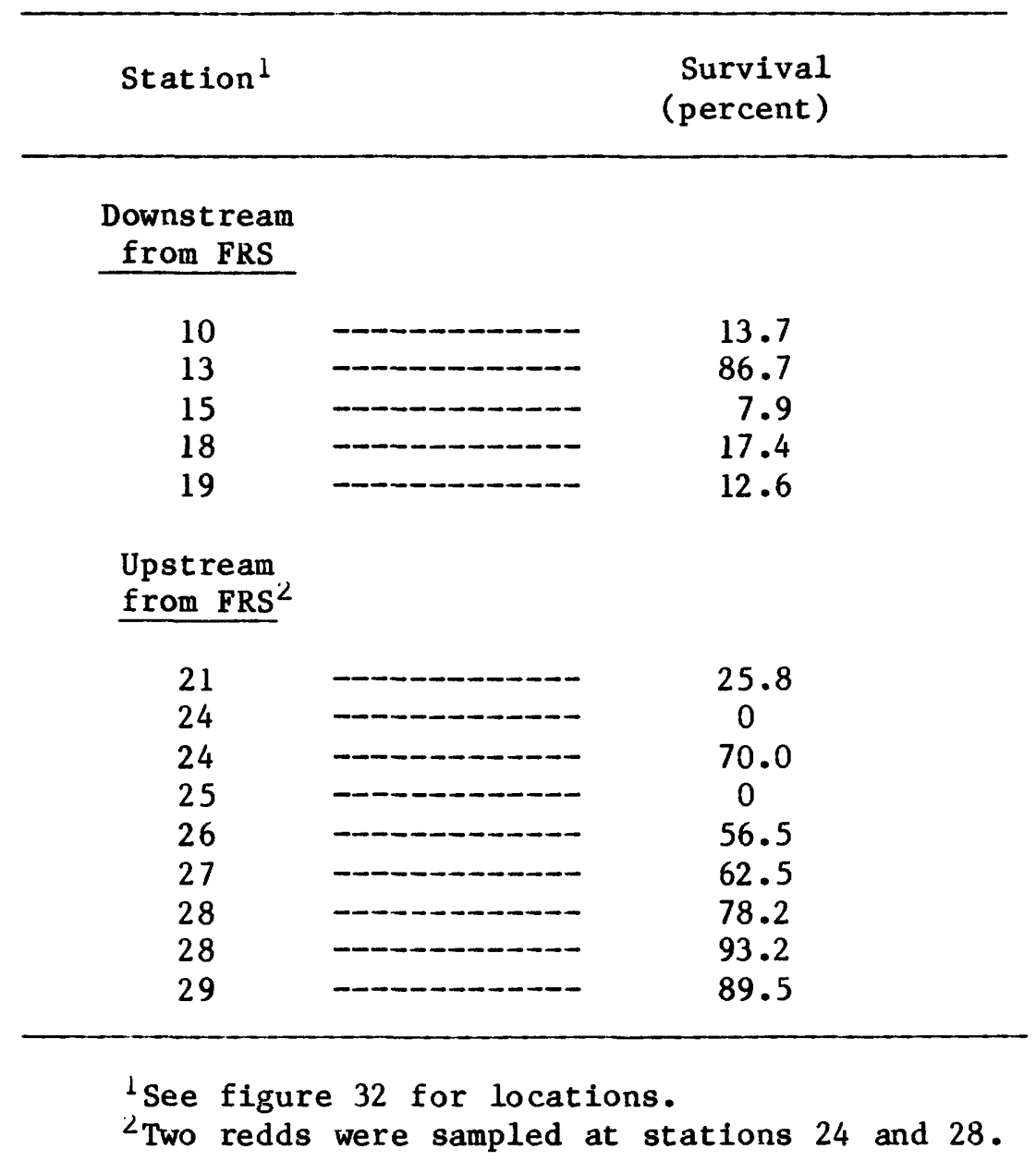

tored in 1975-76; however, a positive correlation between survival of embryos and mean dissolvedoxygen concentration was not apparent. During the 1976-77 reproductive season, good survival was positively correlated with mean dissolved-oxygen concentrations equal to or greater than $6.0 \mathrm{mg} / \mathrm{L}$. (See also Avery, 1980.)

There was a strong positive trend between embryo survival and warmer water temperatures. Stream temperatures, and thus egg-incubation temperatures, were warmer upstream from the FRS where most ground-water discharge occurs (fig. 35). Six of seven redds in which embryo survival was greater than 50 percent in 1976 were upstream from the FRS (table 22). The seventh redd was located downstream from the FRS but also was directly influenced by ground-water discharge. Five of seven redds in which embryo survival exceeded 50 percent also were upstream from the FRS in 1977 (table 23); in 1978 five of nine redds in which embryo survival was greater than 50 percent were upstream from the FRS (table 24).

\section{SUMMARY AND CONCLUSIONS}

Spawning activities of brown trout in Trout Creek begin in late October and extend into January. Peak activity occurs during November, and activity remains high through mid-December. Hatching and emergence take place from February through March. False redds and superimposition were more prevalent downstream from the FRS where substrates suitable for spawning were less abundant. 
Table 23. Embryo survival in trout redds downstream and upstream from the floodwater-retarding structure (FRS), January-February 1977.

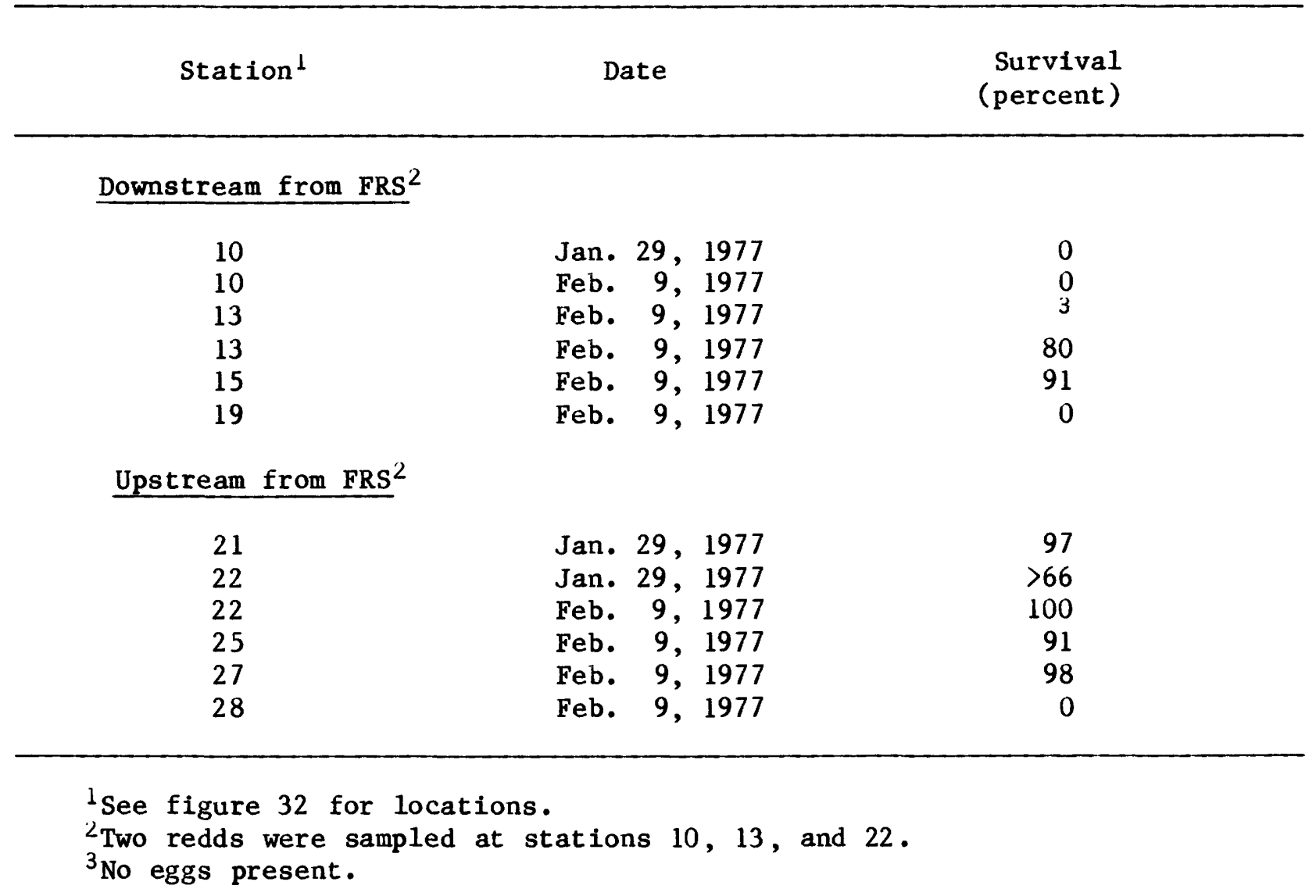

The single most important factor affecting egg survival and fry emergence in Trout Creek during the 3 years of this study was the stream temperature regime. Stream temperatures became progressively colder downstream, and egg survival became poorer. Anchor ice below station 12, downstream from the FRS, destroyed eggs in this reach of Trout Creek in January 1977. The warmer stream temperatures upstream from the FRS also are manifested by faster embryo development, despite the fact that spawning occurs later here than below the FRS.

An important secondary factor affecting egg survival was intragravel dissolved- oxygen concentration. For the stream as a whole, best survival of trout eggs occurred in redds having the highest mean dissolved-oxygen concentrations. Significant differences in intragravel dissolved-oxygen concentrations were not apparent in redds upstream from the FRS compared to those downstream from the FRS.
Water velocity and depth over trout redds declined more upstream from the FRS than downstream from the FRS during the egg-incubation period. Aquatic vegetation, primarily watercress, was far more abundant upstream from the FRS, and by late summer restricted and braided the stream into deep narrow channels with high current velocities. Normal winter die off of watercress occurred in December and January. This decreased water depths and mean current velocities, and allowed sediment, formerly anchored by the vegetation, to erode. No direct effect upon egg survival in trout redds was determined, however, except in one redd which was left partially exposed to freezing air temperatures and in which egg survival was nil.

False redds, superimposition, variability in the number of eggs deposited per redd, and variability in egg survival between redds make redd counts an unreliable index to reproductive potential in trout streams. Repetitive, total redd counts in a specified 
Table 24. Embryo survival in trout redds downstream and upstream frem the floodwater-retarding structure (FRS), February-March 1977.

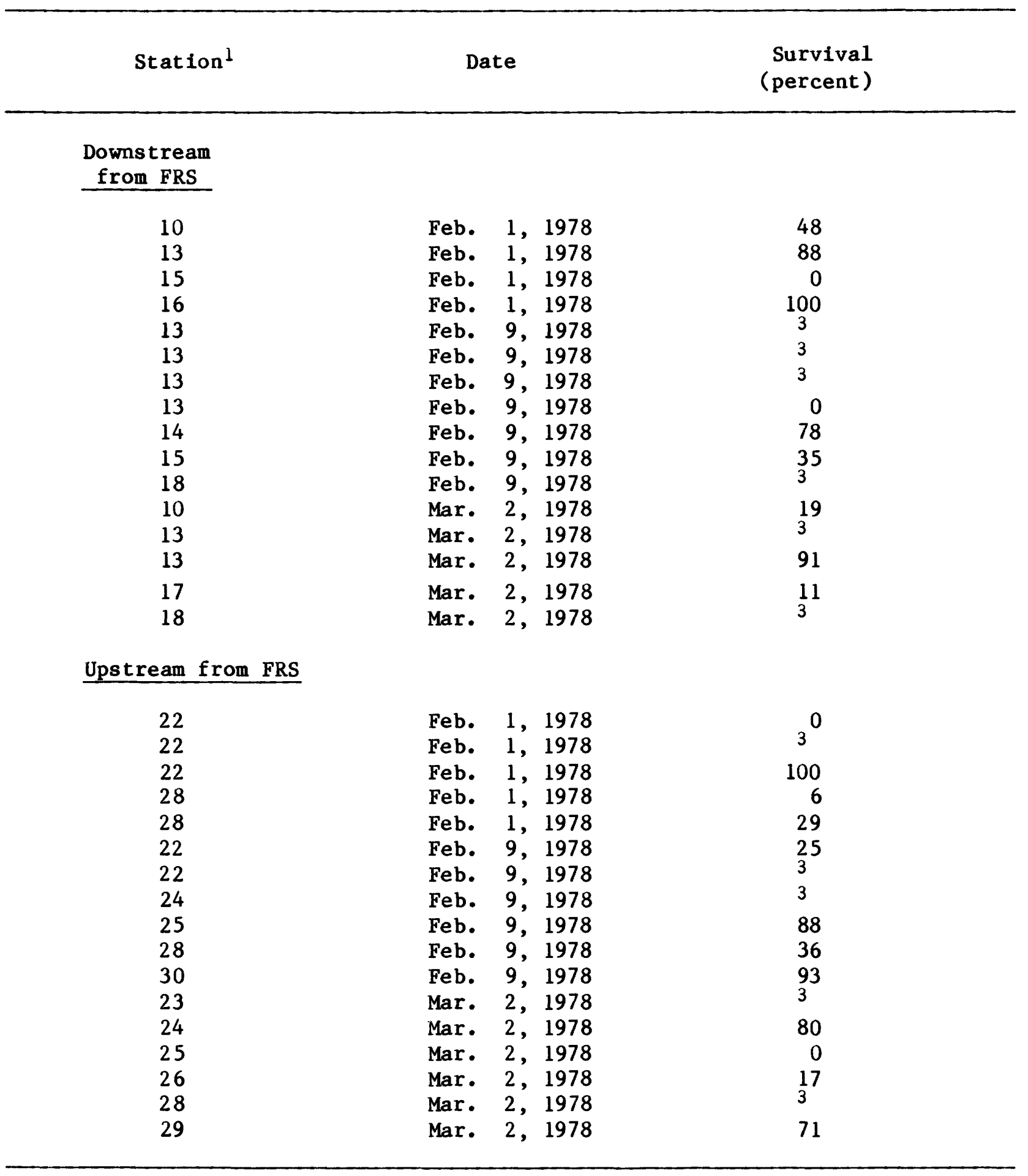

${ }^{1}$ See figure 32 for locations.

2 From 2 to 7 redds were sampled at stations $10,13,15,18,22,24,25$, and 28.

${ }^{3}$ False redds containing $\leq 8$ eggs or sac fry. 
area can indicate a change in substrate quality if sufficient spawners are present and the number of redds increase or decrease appreciably. During this study, the absence of brown trout redds at station 20 just upstream from the FRS was due to the absence of exposed gravels. Before FRS construction, gravel was common in this stream reach, and trout used the area extensively for spawning. Intermittent impoundment of water behind the FRS and subsequent sedimentation of fine materials have destroyed this area for spawning purposes. However, arguments as to whether this loss has affected year class strength of wild brown trout in Trout Creek cannot be substantiated by this study. The FRS had no significant effect upon natural reproduction of brown trout, at least from egg deposition to fry emergence, during the 3 years of this study. This probably was due partly to the relative absence of high water and stream impoundment until after the majority of fry had emerged from the streambed.

Finally, with the initiation of this study by the Wisconsin Department of Natural Resources, the maintenance of the spillway pipe through the FRS was improved. Before this study, debris often partially plugged the flared end-section inlet of the pipe and was responsible for extended periods of stream impoundment following major storms. The extended impoundment of water subjected the stream reach downstream from the FRS to abnormally long periods of sedimentation due to the release of turbid water from the impoundment. Proper maintenance of the pipe inlet also has resulted in some improvement of the streambed upstream from the FRS. Proper maintenance of such inlets allows them to function as designed, particularly during the spawning and incubation periods for trout. 


\title{
Trout Populations
}

\author{
By O. M. Brynildson ${ }^{1}$
}

\section{INTRODUCTION}

Research on trout populations of Trout Creek began in 1960. Until 1973, the focus of this research was to determine survival and growth of domesticated brook (Salvelinus fontinalis), brown (Salmo trutta), and rainbow (Salmo gairdneri) trout stocked as fingerlings (age 0 , that is, less than 1 year old) in the lower $2 \mathrm{mi}$ of the stream during June or October (Brynildson, 1965; Mason and others, 1966). Since 1973, the principal objective of the study has been to determine the impact, on the wild brown trout population, of construction of a floodwater-retarding structure (FRS) in an area of Trout Creek containing prime trout-spawning grounds.

During floods, Trout Creek is subjected to channel erosion. When these floods occur during winter, they can kill developing trout eggs and sac fry in the gravel (redds) when the gravel is washed away by the flood waters. This can result in partial or near destruction of a potential year class of wild trout. Such flood damage to trout redds is well documented (Allen, 1951; Brynildson, 1956, 1957; McFadden and Cooper, 1962; White, 1962, 1964; Frankenburger and Fassbender, 1967; Elwood and Waters, 1969; Seegrist and Gard, 1972; Brynildson and Mason, 1975).

\section{DESCRIPTION OF THE STUDY AREA}

The study area begins at Arndt Spring and continues to the confluence of Mill and Trout Creeks, $5.1 \mathrm{mi}$ downstream (fig. 32). Thirty stations, each about $300 \mathrm{yd}$ in length were established in this stream reach.

Since observations were begun in 1960 , the study area has been ice free during the winter from approximately $165 \mathrm{ft}$ upstream from Arndt Spring (station 29) downstream to station 19. Edge ice forms during the coldest periods from stations 19 to 14. From stations 14 to 9 , ice cover is intermittent; downstream from station 9, ice covers the stream during normal winters.

During the relatively cold winter of 1976-77, anchor ice formed on a gravel cattle crossing at station 10 (1.8 mi downstream from the FRS). This was as far downstream as trout redds were found during the study. Trout redds were present at this station in November 1975 and 1976; but trout eggs in these redds never developed to the sac-fry stage, due to freezing water temperatures.

Water temperatures in the study area rarely exceed $24^{\circ} \mathrm{C}$ during the summer (U.S. Geological Survey, 1978, 1979, 1980). This temperature has been suggested as the upper limit for short-term survival of brook trout (U.S. Environmental Protection Agency, 1976). Water temperatures upstream from the study area may become too warm for trout (except near springs) during most summers. However, during winter, a few trout (probably fall migrants from the study area downstream) have been captured by electrofishing, upstream from the study area, and anglers have reported catching trout here during spring and fall.

\section{EFFECTS OF THE FRS ON UPSTREAM MOVEMENT OF FISH}

In 1964 , there was speculation whether the 12-in. high waterfall from the pipe exit of the FRS and the high velocity of water flowing through the pipe were barriers to upstream movement of trout, white suckers, and other fishes in Trout Creek. Therefore, on September 8, 1964, 64 wild brown trout (age 1 and older; 8-17 in.) and 81 wild brownand 24 wild rainbow-trout fingerlings (age 0; 4-6 in.) from stations 24-26 upstream from the FRS were captured, marked, and transferred to stations 17-19 downstream from the FRS. In addition to the trout, 189 white suckers (4-14 in.) collected from stations 24-26 also were marked and transferred to stations 17-19.

During a trout population estimate conducted September 15-21, 1964, three of the transferred rainbow-trout fingerlings and eight of the transferred, age 1 and older, brown trout were recaptured upstream from the FRS, indicating they had migrated upstream through the pipe despite the 12-in. waterfall. None of the transferred browntrout fingerlings or white suckers were captured upstream from the FRS. Moreover, none of the transferred brown-trout fingerlings or the white suckers were found upstream from the FRS during a trout population estimate conducted April 22-24,

\footnotetext{
${ }^{1}$ Wisconsin Department of Natural Resources, Route 1, Box 66, Black River Falls, Wisconsin 54615.
} 
1965, a period when the white sucker upstream spawning run occurs.

By 1973, the height of the waterfall from the pipe exit of the FRS had increased to 26 in. due to erosion of the lip of the stilling basin. To determine whether this waterfall would block the October upstream spawning run of wild brown trout from below the FRS, the anal fins were removed from 159 spawning-age (age 2 and older; 10-19 in.) wild brown trout in the study area downstream from the FRS during a trout population estimate on September 17-20, 1973. In addition, on September 18, 1973, 30 wild brown trout (age 3; 12-19 in.) were captured at stations 25-26 upstream from the FRS, their dorsal fins were removed, and these spawning-age trout were released into the stilling basin below the FRS. Of the 159 spawning-age wild brown trout marked downstream from the FRS and the 30 wild brown trout that were transferred from above the FRS to below the FRS, 22 and 18, respectively, were recaptured by electrofishing at stations 20-29 upstream from the FRS on October 24, 1973 (C. Brynildson, oral commun., 1979).

Brook, brown, and rainbow trout that were stocked in the stream downstream from the FRS rarely were found during electrofishing in the stream upstream from the FRS. The occasional stocked trout captured upstream from the FRS would usually be a spawning-age brown trout; these account for less than 1 percent of the stocked brown trout. Before construction of the FRS in 1964, a reiatively high number of brown-trout fingerlings stocked May 20, 1963, at stations 5-10 (fig. 31) had moved upstream to station 29 by September 1963 (Brynildson, 1967).

Upstream migrating (from Mill Creek, fig. 32) northern pike, hybrid muskellunge, grass pickerel, bluegills, largemouth bass, burbot, and carp have never been captured upstream from the FRS during electrofishing conducted as part of this study. These fishes were present in the study area upstream from the site of the FRS before the structure was completed in 1964. The FRS apparently is a barrier to these fishes and, thus, benefits the wild browntrout population upstream from the FRS by: (1) eliminating competition for food and living space from stocked trout and other migrating fishes, and (2) eliminating trout predators, such as northern pike and hybrid muskellunge, which feed mainly on trout below the FRS. Stomachs of northern pike and hybrid muskellunge captured downstream from the FRS during 1976-79 contained mainly trout (up to 11 in.). The rest of the stomachs examined were either empty or contained the abundant white sucker.

\section{REPRODUCTION}

The potential number of wild brown trout fry emerging from redds in Trout Creek during February and March was calculated from the estimated egg production of the female parent as determined for wild brown trout in New Zealand (Allen, 1951). The estimate of 80 percent fry emerging from the redds was based on the observed average success of egg development to sac fry within the redds in Trout Creek during flood-free winters. During such winters, even when wild mature female trout were relatively few in number, they still produced a relatively large number of September fingerlings (table 25). Before October 1975, determination of the relative magnitudes of winter floods was based on records from the U.S. Geological Survey's streamflow gaging station, 05406500, Black Earth Creek at Black Earth, $15 \mathrm{mi}$ to the northeast. For October 1975 through September 1979, this determination was based on streamflow data collected by the U.S. Geological Survey at Trout Creek.

During this study, winter floods appear to have had a greater influence on survival of developing trout eggs and sac fry than any other observed environmental factor in Trout Creek (table 25). Sediment deposition from standing water temporarily ponded by the FRS may have smothered developing trout eggs and sac fry by depriving them of adequate oxygen. It is also possible that fry upstream from the standing water were carried downstream by floods. Instead of continuing downstream, perhaps to some safety below the FRS, they could have been interrupted by the standing water behind the FRS. Here the fry could have spread out in the ponded water and become stranded among winter remains of the tall and densely growing, nonwoody vegetation as the ponded water receded.

Survival of potential February and March trout fry to September fingerlings in Trout Creek ranged from 0.2 to 4.5 percent with an average of 1.5 percent over the 20-year span of investigation (table 25). This survival rate is similar to that in Black Earth and Mt. Vernon Creeks in Dane County. In these two similar streams, survival of potential February and March trout fry to September fingerlings averaged 1.7 and 1.2 percent, respectively, for the period 1955-72. For those February and March 
Table 25. Potential reproduction and estimated survival of various year classes of wild brown trout to September fingerlings (age 0 ).

\begin{tabular}{|c|c|c|c|c|c|}
\hline $\begin{array}{c}\text { Year class } \\
\text { (year } \\
\text { hatched) }\end{array}$ & $\begin{array}{l}\text { Number of mature } \\
\text { females preceding } \\
\text { September }{ }^{1}\end{array}$ & $\begin{array}{l}\text { Potential number } \\
\text { of eggs deposited } \\
\text { in November }\end{array}$ & $\begin{array}{l}\text { Potential number } \\
\text { of fry in } \\
\text { February-March }\end{array}$ & $\begin{array}{l}\text { Number of } \\
\text { fingerlings } \\
\text { in September }\end{array}$ & $\begin{array}{l}\text { Survival of fry } \\
\text { to September } \\
\text { fingerlings } \\
\text { (percent) }\end{array}$ \\
\hline $\begin{array}{l}1960 \\
1961 \\
1962 \\
1963 \\
1964\end{array}$ & $\begin{array}{r}112 \\
116 \\
43 \\
58 \\
91\end{array}$ & $\begin{array}{r}121,440 \\
125,280 \\
46,580 \\
53,500 \\
84,300\end{array}$ & $\begin{array}{r}97,150 \\
100,220 \\
37,260 \\
42,800 \\
67,440\end{array}$ & $\begin{array}{r}487 \\
826 \\
1,678 \\
1,539 \\
1,402\end{array}$ & $\begin{array}{r}20.5 \\
2.8 \\
4.5 \\
3.6 \\
2.1\end{array}$ \\
\hline $\begin{array}{l}1965 \\
1966 \\
1967 \\
1968 \\
1969\end{array}$ & $\begin{array}{l}148 \\
162 \\
218 \\
123 \\
188\end{array}$ & $\begin{array}{l}156,850 \\
139,360 \\
217,500 \\
143,480 \\
169,530\end{array}$ & $\begin{array}{l}125,480 \\
111,490 \\
174,080 \\
114,880 \\
135,620\end{array}$ & $\begin{array}{r}428 \\
2,113 \\
777 \\
3,168 \\
4,142\end{array}$ & 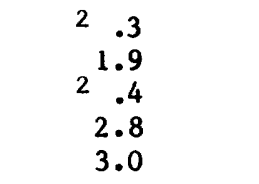 \\
\hline $\begin{array}{l}1970 \\
1971 \\
1972 \\
1973 \\
1974\end{array}$ & $\begin{array}{l}153 \\
287 \\
499 \\
202 \\
352\end{array}$ & $\begin{array}{l}155,860 \\
265,530 \\
307,460 \\
202,640 \\
324,860\end{array}$ & $\begin{array}{l}124,690 \\
212,420 \\
245,970 \\
162,110 \\
259,890\end{array}$ & $\begin{array}{r}2,918 \\
1,672 \\
663 \\
351 \\
1,645\end{array}$ & $\begin{array}{lr}2 & .3 \\
2 & .8 \\
2 & .3 \\
2 & .3 \\
2 & .6\end{array}$ \\
\hline $\begin{array}{l}1975 \\
1976 \\
1977 \\
1978 \\
1979\end{array}$ & $\begin{array}{l}216 \\
101 \\
188 \\
345 \\
336\end{array}$ & $\begin{array}{l}207,800 \\
108,260 \\
168,560 \\
293,700 \\
341,040\end{array}$ & $\begin{array}{r}166,240 \\
86,610 \\
134,480 \\
234,960 \\
272,830\end{array}$ & $\begin{array}{r}2,002 \\
536 \\
972 \\
2,876 \\
3,498\end{array}$ & $\begin{array}{rr} & 1.2 \\
2 & .6 \\
2 & .7 \\
1.2 \\
1.3\end{array}$ \\
\hline Mean & 197 & 181,680 & 133,030 & 1,685 & 1.5 \\
\hline
\end{tabular}

\footnotetext{
lMature wild female brown trout outnumbered the wild male brown trout by an average of 60 percent (range 51-68) during the 20 years of investigation.

2 Years of recorded winter floods.
}

fry that live to become September fingerlings, survival rate is relatively high during the following 6 to 7 months. For example, in Trout Creek the overwinter survival of the September fingerlings (4-5 in.) to the following April was 72 percent at stations 28-29 during 1978-79.

No reproduction of trout has occurred at station 20 since the FRS was completed. The gravel, needed by trout for spawning, was covered by sediment from the lower half of station 21 through station 20 after the water velocity dropped due to ponding by the debris-clogged flared end-section inlet of the spillway pipe through the FRS. The sediment deposited in the lower half of station 21 eroded during the 4 years that hte pipe inlet manually was kept free of debris. As a result, the amount of gravel exposed in the lower half of station 21 increased during that period.

\section{DISTRIBUTION AND DENSITY}

Estimates of the trout populations in the Trout Creek study area began in September 1960 and continued through 1979. Estimates were made during April or early May and during September. Direct-current electrofishing units were employed to capture trout for estimates of their population within each of the 30 stations in the study area. The mark and recapture method employed was based on two runs with the electrofishing units. Details on the procedure and the efficiency of the electrofishing technique are discussed by McFadden (1961), Hunt, Brynildson, and McFadden (1962), and White (1964). Recapture values, during the second run, on trout 4 to 6 in. were 50 to 60 percent of the original numbers captured, marked, and released. On larger trout, recapture values rose to 70 to 90 
percent. For future identification of wild brown trout year classes, specific fins were removed from different year classes. Fingerlings from each year class (age 0) were marked in September, and unmarked yearlings (age 1) were marked during the following spring. All trout captured on the first run were weighed and measured.

Numbers of September fingerlings downstream from the FRS have been relatively stable since the structure was completed in 1964, even though winter floods and ponded water have killed trout eggs and fry upstream from the FRS. This stability of September fingerlings probably is due to the controlled streamflow below the FRS. For example, floods during early 1972, 1973, and 1976 all but eliminated the 1972, 1973, and 1976 year classes ${ }^{1}$ upstream from the FRS but did not affect the September fingerling numbers downstream from the FRS. In September 1972, 1973, and 1976, when fingerling populations were low in the study area, 90,86 , and 89 percent, respectively, of the fingerling numbers were resident downstream from the FRS. This compares to 24,17 , and 27 percent in September 1969, 1978, and 1979, respectively, when prior winter streamflow in Trout Creek was relatively stable.
The number of September fingerlings decreased sharply at station 20 (just upstream from the FRS) after 1964 when the FRS was completed (table 26). The relatively high number of fingerlings at station 20 during September 1979 may be attributed to a drift of fry and fingerlings from upstream stations, for example, stations 28-29, where fingerling numbers (table 26) and population pressures were high.

Apparently, the adult wild brown trout have compensated for the lost spawning grounds at stations 20 and 21 by utilizing spawning grounds at stations 23-29 more extensively and intensively, because most of the trout reproduction has occurred there since 1976. The wild brown trout at stations 28-29 during 1978-79 had reached their highest population levels recorded during the 20 years of this investigation. In September 1979, numerical density of wild brown trout at stations $28-29$ was 60 trout per $100 \mathrm{~m}^{2}$, of which 63 percent were fingerlings. Their combined biomass reached $32.8 \mathrm{~g} / \mathrm{m}^{2}$ (adults; $29.0 \mathrm{~g} / \mathrm{m}^{2}$ ). Station 28 alone contained 64 wild brown trout per $100 \mathrm{~m}^{2}$, of which 61 percent were fingerlings. Their combined biomass reached $38.8 \mathrm{~g} / \mathrm{m}^{2}$ (adults; $34.0 \mathrm{~g} / \mathrm{m}^{2}$ ), the highest recorded during the 20-year study. In comparison, the highest biomass of wild brown trout recorded in Black

${ }^{1}$ A year class is designated by the year in which hatching occurs; hatching of trout eggs normally occurs during February and March in Trout Creek.

Table 26. Number of wild brown trout fingerlings (age 0 ) per 100 square meters during September.

\begin{tabular}{|c|c|c|c|c|c|c|c|}
\hline 1962 & 1963 & 1964 & 1966 & 1969 & 1975 & 1978 & 1979 \\
\hline \multicolumn{8}{|c|}{ Stations $17-19^{2}$} \\
\hline 8.4 & 2.7 & 7.9 & 6.6 & 10.6 & 4.6 & 5.7 & 4.0 \\
\hline \multicolumn{8}{|c|}{ Station $20^{2}$} \\
\hline 11.2 & 11.4 & 22.2 & 5.2 & .7 & 1.0 & .2 & 7.6 \\
\hline \multicolumn{8}{|c|}{ Station $21^{2}$} \\
\hline 6.8 & 20.0 & 6.0 & 18.9 & 34.1 & 2.8 & 1.5 & 7.8 \\
\hline \multicolumn{8}{|c|}{ Stations $28-29^{2}$} \\
\hline 11.2 & 6.1 & 8.9 & 6.9 & 27.0 & 6.8 & 24.0 & 37.7 \\
\hline
\end{tabular}


Earth Creek was $45.8 \mathrm{~g} / \mathrm{m}^{2}$ in a section receiving nutrients from a sewage-treatment facility (Brynildson and Mason, 1975).

\section{PRODUCTION}

Production of trout is defined as the growth in weight by all trout in the population during a period of time, including growth by trout that died during that period. Production was calculated for each year class of trout as the product of the average standing crop and its instantaneous rate of growth during the period of production. The average weight of individual wild brown trout fry at time of emergence from redds was assumed to be $0.1 \mathrm{~g}$, based on data from Bagenal (1969).

Trout production in relation to biomass in Trout Creek was fairly uniform at various stations during different years (table 27). The high number of wild brown trout at stations 28-29 during the September 1978 to September 1979 period depressed the growth rate but not production in relation to biomass; this resulted because of the high number of fast-growing fingerling trout, which have relatively higher efficiency of production than slowergrowing adult trout. At stations 28-29 during this period, the production/biomass ratio was 5.5 for the fingerling trout, compared to 0.8 for the adult trout. Fingerling trout accounted for 50 percent of the total production by all wild trout at stations 28-29 during the period September 1978 to September 1979. During that period, total production by all trout combined at stations 28-29 reached 36.0 $\mathrm{g} / \mathrm{m}^{2}$, the highest recorded in Trout Creek (table 27). This figure is close to the highest recorded production $\left(39.6 \mathrm{~g} / \mathrm{m}^{2}\right)$ for wild brown trout in Black Earth Creek (Brynildson and Mason, 1975).

\section{SUMMARY AND CONCLUSIONS}

The results of this study indicate that winter floods have had a greater adverse effect on the survival of developing trout eggs and sac fry in

Table 27. Density and annual production of wild brown trout.

\begin{tabular}{|c|c|c|c|c|c|c|c|}
\hline Station ${ }^{1}$ & & $\begin{array}{l}\text { Periods of } \\
\text { production }\end{array}$ & & $\begin{array}{c}\text { Number of } \\
\text { trout/ } \\
100 \mathrm{~m}^{2}\end{array}$ & $\begin{array}{l}\text { Biomass } \\
\left(\mathrm{g}^{2}\right)\end{array}$ & $\begin{array}{l}\text { Production } \\
\left(\mathrm{g}^{2}\right)\end{array}$ & $\begin{array}{l}\text { Production/ } \\
\text { biomass } \\
\text { ratio }\end{array}$ \\
\hline $7-8$ & $\begin{array}{l}\text { Sept. } \\
\text { Sept. } \\
\text { Sept. } \\
\text { Sept. }\end{array}$ & $\begin{array}{l}\text { 1962-Sept. } \\
\text { 1966-Sept. } \\
\text { 1974-Sept. } \\
\text { 1978-Sept }\end{array}$ & $\begin{array}{l}1963 \\
1967 \\
1975 \\
1979\end{array}$ & $\begin{array}{l}2.5 \\
1.8 \\
4.0 \\
3.3\end{array}$ & $\begin{array}{l}2.1 \\
2.0 \\
1.0 \\
3.6\end{array}$ & $\begin{array}{l}2.9 \\
1.6 \\
3.3 \\
4.2\end{array}$ & $\begin{array}{l}1.4 \\
.80 \\
3.3 \\
1.2\end{array}$ \\
\hline $17-19$ & $\begin{array}{l}\text { Sept. } \\
\text { Sept. } \\
\text { Sept. } \\
\text { Sept. }\end{array}$ & $\begin{array}{l}\text { 1962-Sept. } \\
\text { 1966-Sept. } \\
\text { 1974-Sept. } \\
\text { 1978-Sept. }\end{array}$ & $\begin{array}{l}1963 \\
1967 \\
1975 \\
1979\end{array}$ & $\begin{array}{l}7.4 \\
6.8 \\
5.5 \\
8.0\end{array}$ & $\begin{array}{l}4.2 \\
4.5 \\
3.5 \\
4.2\end{array}$ & $\begin{array}{l}5.5 \\
7.6 \\
4.4 \\
4.0\end{array}$ & $\begin{array}{l}1.3 \\
1.7 \\
1.3 \\
.95\end{array}$ \\
\hline $20-21$ & $\begin{array}{l}\text { Sept. } \\
\text { Sept. } \\
\text { Sept. } \\
\text { Sept. }\end{array}$ & $\begin{array}{l}\text { 1962-Sept. } \\
\text { 1966-Sept. } \\
\text { 1974-Sept. } \\
\text { 1978-Sept. }\end{array}$ & $\begin{array}{l}1963 \\
1967 \\
1975 \\
1979\end{array}$ & $\begin{array}{r}16.4 \\
7.1 \\
6.6 \\
9.2\end{array}$ & $\begin{array}{l}5.0 \\
4.8 \\
4.9 \\
8.4\end{array}$ & $\begin{array}{r}10.8 \\
7.3 \\
10.8 \\
9.0\end{array}$ & $\begin{array}{l}2.2 \\
1.5 \\
2.2 \\
1.1\end{array}$ \\
\hline $28-29$ & $\begin{array}{l}\text { Sept. } \\
\text { Sept. } \\
\text { Sept. } \\
\text { Sept. }\end{array}$ & $\begin{array}{l}\text { 1962-Sept. } \\
\text { 1966-Sept. } \\
\text { 1974-Sept. } \\
\text { 1978-Sept. }\end{array}$ & $\begin{array}{l}1963 \\
1967 \\
1975 \\
1979\end{array}$ & $\begin{array}{l}12.3 \\
14.8 \\
13.9 \\
51.7\end{array}$ & $\begin{array}{r}5.8 \\
16.1 \\
8.3 \\
25.1\end{array}$ & $\begin{array}{r}9.5 \\
15.7 \\
10.7 \\
36.0\end{array}$ & $\begin{array}{l}1.6 \\
.98 \\
1.3 \\
1.4\end{array}$ \\
\hline
\end{tabular}

${ }^{1}$ See figure 32 for locations. 
Trout Creek than any other environmental factor. This may result when sedimentation from ponded water behind the floodwater-retarding structure (FRS) suffocates eggs and fry, and (or) when fry are stranded beyond the channel after the ponded water recedes. No reproduction of trout has occurred at station 20 immediately upstream from the FRS since its completion in 1964 . When the spawning grounds at station 20 and the lower half of station 21 were covered by sediment deposited from ponded water behind the debris-clogged flared end-section inlet of the spillway pipe through the FRS, spawning trout apparently compensated by using spawning grounds at stations 23-29 more extensively and intensively. The sediment covering the lower half of station 21 eroded during the period October 1975 through September 1979, when the inlet manually was kept free of debris.

The destruction of prime trout spawning grounds above the FRS due to sedimentation and to standing water cannot be alleviated easily. Installation of stream deflectors in the channel of the stream flowing through the FRS flood pool to remove and prevent deposition of sediments on spawning gravel during normal flow conditions would attract spawning trout to these areas, only to have their progeny suffocate in the developing egg and sac-fry stages by sediment-laden standing water from winter floods. Leaving the channel just upstream from the FRS as is would encourage trout to continue further upstream to spawn above the flood pool of the FRS, where some of the spawning gravel is inferior but where water temperatures and sediment deposition are moderate.

There have been no obvious adverse effects of the FRS on trout production in Trout Creek.

Positive factors of the FRS include: (1) the controlled water flow below the structure during winter floods has been a stabilizing influence on the limited trout reproduction below the structure; (2) the FRS blocks the upstream movement of fishes competing with and preying on the wild trout population above the FRS, but does not block the upstream migration of spawning wild trout. 


\title{
Summary of Findings
}

\author{
By David J. Graczyk ${ }^{1}$
}

The floodwater-retarding structure (FRS) on Trout Creek, Wis., influences the hydrology and, in turn, the trout fishery both upstream and downstream from the structure.

The FRS attentuates flood peaks: reductions during the study ranged from 58 to 92 percent. Flood discharges from the FRS generally were between 58 and $71 \mathrm{ft}^{3} / \mathrm{s}$; this is about equal to the independently determined bankfull capacity of 65 $\mathrm{ft}^{3} / \mathrm{s}$ to which the channel just downstream from the FRS has adjusted. The FRS also extends the time base of flood hydrographs.

There is considerable channel storage upstream from the FRS. When high flows enter the area of the flood-storage pool, stream velocities decrease, and much of the sediment is deposited on the channel bottom. Consequently, sediment concentrations in the outflow from FRS decrease. When the pool begins to recede, velocities in the channel increase, and the sediment is remobilized and flushed downstream. Thus, sediment concentrations in the outflow increase, while discharge from the FRS decreases. This remobilization and removal of sediment during flood recession contributes to the low sediment-trapping efficiency of about 7 percent for the period of study. Suspended-sediment concentrations remain high below the FRS for extended periods (up to several months) following storms; above the FRS flood pool, sediment concentrations normally remain high only for several days.

The FRS also has caused changes in the channel morphology downstream from the structure. The bankfull discharge just downstream from the FRS has been reduced to less than one-half the upstream value (from 154 to $65 \mathrm{ft}^{3} / \mathrm{s}$ ). Just downstream from the FRS, the channel is slightly wider and considerably shallower than upstream. The channel in this area has adjusted to reduced streamflow by depositing sediment eroded from the flood pool of the FRS during low flows. Farther downstream, near the mouth of Trout Creek, channel geometry and hydraulic geometry relationships indicate little effect of the FRS.

Despite the influences on streamflow, sedimentation processes, and channel morphology, there have been no obvious effects of the FRS on the arthropod fauna of Trout Creek.

Within a given reproductive season, the most important factor affecting egg survival and fry emergence of brown trout in Trout Creek from the fall of 1975 to the winter of 1978 was the stream temperature regime. Stream temperatures became progressively lower downstream, and egg survival was poorer. Higher stream temperatures upstream from the FRS resulted from greater ground-water discharges in this area; these higher temperatures contributed to faster embryo development, despite the fact that spawning occurred 1 to 2 weeks later here than downstream from the FRS.

A secondary factor affecting brown trout survival was intragravel dissolved-oxygen concentration. Best survival of trout eggs occurred in redds with highest mean dissolved-oxygen concentrations. There were no significant differences in intragravel dissolved-oxygen concentration upstream and downstream from the FRS.

The FRS was not found to have any significant effect upon natural reproduction, from egg deposition to fry emergence, from the fall of 1975 to the winter of 1978 . This probably was due, at least partly, to the relative absence of floods and stream impoundment during this period. In contrast to this, winter floods did occur during the period from 1960 to 1979 , and they appear to have had a greater adverse effect on the survival of trout eggs and sac fry than any other environmental factor.

The absence of brown trout redds at station 20 just upstream from the FRS, since its completion in 1964 , is due to the absence of exposed gravels. Before FRS construction, gravel was common and trout used this area for spawning. Impoundment of water during storms deposits fine materials and has destroyed this area for spawning purposes. When spawning grounds just upstream from the FRS were covered by sediment, trout apparently compensated by utilizing spawning grounds farther upstream more extensively and intensively. Continued use of these upstream spawning grounds is encouraged by not attracting spawning trout to the channel of the flood pool through the use of stream deflectors.

\footnotetext{
${ }^{1}$ U.S. Geological Survey, 1815 University Avenue, Madison, Wisconsin 53706.
} 
Trout production apparently has not been affected by construction of the FRS.

The FRS has provided some advantages (1) by controlling streamflow and thus stabilizing the limited trout reproduction downstream from the structure, and (2) by blocking upstream movement of fishes that compete with and prey on the trout population.

Location of the FRS at an alternate site so that trout-spawning grounds were not intersected by the structure nor flooded by impounded water would have eliminated direct effects on wild trout reproduction. Construction at a site farther downstream would have had additional benefits by protecting a greater upstream reach from competition and predation by other fish species. However, alternate locations and the benefits derived must be tempered with possible increased costs of construction at a less ideal site.

Effects of the FRS on sediment transport and channel morphology would have been minimized by installation of a pipe designed to pass the bankfull discharge that existed before FRS construction. Regular maintenance of the structure, that is removal of debris clogging the inlet following floods, should prevent large accumulations in the channel upstream from the FRS and extended periods of sediment-laden streamflows downstream from the FRS. 


\section{References}

Alderdice, D. F., Wickett, W. P., and Brett, J. P., 1958, Some effects of temporary exposure to low dissolved oxygen levels on Pacific salmon eggs: Journal of the Fisheries Research Board of Canada, v. 15, p. 229-249.

Allen, K. R., 1951, The Horokivi stream, a study of a trout population: New Zealand Marine Department Fisheries Bulletin, no. 10, 231 p.

Avery, E. L., 1980, Factors influencing reproduction of brown trout above and below a flood water detention dam on Trout Creek, Wisconsin: Madison, Wisconsin Department of Natural Resources, Research Report 106, 26 p.

Bagenal, T. B., 1969, The relationship between food supply and fecundity in brown trout Salmo trutta L.: Journal Fishery Biology, v. 1, p. 167-182.

Bean, E. F., 1949, Geologic maps of Wisconsin: Wisconsin Geological and Natural History Survey map, scale $1: 1,000,000$.

Brune, G. M., 1953, Trap efficiencies of reservoirs: Transactions of the American Geophysical Union, v. 34, p.407-418.

Brynildson, O. M., 1956, The reproductive potential in Mt. Vernon, Black Earth and Dell Creeks: Madison, Wisconsin Conservation Department, Southern Area Investigational Memorandum, No. 174, Dingell-Johnson Project F-4-R-3, 4 p.

---1957, Success of natural reproduction of trout in Mt. Vernon and Black Earth Creeks: Madison, Wisconsin Conservation Department Annual Progress Report, Dingell-Johnson Project F4-R-4, 4 p.

---1965, Survival of trout stocked at different sizes: Madison, Wisconsin Conservation Department Fishery Research Quarterly Report, April-June, $5 \mathrm{p}$.

---1967, Dispersal of stocked trout in five Wisconsin streams: Madison, Wisconsin Conservation Department Research Report (Fisheries), No. $26,30 \mathrm{p}$.

Brynildson, O. M., and Mason, J. W., 1975, Influence of organic pollution on the density and production of trout in a Wisconsin stream: Madison, Wisconsin Department of Natural Resources Technical Bulletin No. 81, 61 p.

Buchanan, T. J., and Somers, W. P., 1968, Stage

- measurement at gaging stations: U.S. Geological Survey Techniques of Water-Resources Investigations, Book 3, Chapter A7, 28 p.

---1969, Discharge measurements at gaging stations: U.S. Geological Survey Techniques of Water-Resources Investigations, Book 3, Chapter A8, $65 \mathrm{p}$.
Cheetham, R. N., Jr., and Wilke, R. F., 1976, Sedimentation in Birch Lake, Iowa County, Wisconsin, in Proceedings of the Third Federal Inter-Agency Sedimentation Conference, Denver, Colorado, March 22-25, 1976: National Technical Information Service Report PB 245 100 , p. 1-110 to 1-122.

Coble, D. W., 1961, Influence of water exchange and dissolved oxygen in redds on survival of steelhead trout embroys: Transactions of the American Fisheries Society, v. 90, p. 469-474.

Colby, B. R., 1963, Fluvial sediments--A summary of source, transportation, deposition, and measurement of sediment discharge: U.S. Geological Survey Bulletin 1181-A, 47 p.

Colby, B. R., and Hembree, C. H., 1955, Computations of total sediment discharge, Niobrara River near Cody, Nebraska: U.S. Geological Survey Water-Supply Paper $1357,187 \mathrm{p}$.

Colby, B. R., and Hubbell, D. W., 1961, Simplified methods for computing total sediment discharge with the modified Einstein procedure: U.S. Geological Survey Water-Supply Paper $1593,17 \mathrm{p}$.

Curtis, L. W., 1965, Sedimentation in the Miami Conservancy District's retarding basins: Dayton, Ohio, Miami Conservancy District, 27 p.

Dalrymple, Tate, and Benson, M. A., 1967, Measurement of peak discharge by the slope-area method: U.S. Geological Survey Techniques of Water-Resources Investigations, Book 3, Chapter A2, $12 \mathrm{p}$.

Dunne, Thomas, and Leopold, L. B., 1978, Water in environmental planning: San Francisco, W. H. Freeman and Co., $818 \mathrm{p}$.

Elwood, J. W., and Waters, T. F., 1969, Effects of floods on food consumption and production rates of a stream brook trout population: Transactions of the American Fisheries Society, v. 98, p. 253-262.

Emmett, W. W., 1972, The hydraulic geometry of some Alaskan streams south of the Yukon River: U.S. Geological Survey open-file report, $102 \mathrm{p}$.

---1975, The channels and waters of the Upper Salmon River area, Idaho: U.S. Geological Survey Professional Paper 870-A, 116 p.

Environmental Data Service, 1973, Monthly normals of temperature, precipitation, and heating and cooling degree days for Wisconsin: Washington, D.C., U.S. Department of Commerce, Climatography of the United States, no. 81.

-.-1974-79, Climatological data--annual summary for Wisconsin: Washington, D.C., U.S. Department of Commerce, v. 79-84. 
Frankenberger, Ludwig, and Fassbender, Ronald, 1967, Evaluation of the effects of the habitat management program and the watershed planning program on the brown trout fishery in Bohemian Valley Creek, La Crosse County: Madison, Wisconsin Department of Natural Resources, Management Report No. 16, 19 p.

Gebert, W. A., 1978, Low-flow characteristics of streams in the lower Wisconsin River basin: U.S. Geological Survey Water-Resources Investigations 77-118, $80 \mathrm{p}$.

Gottschalk, L. C., 1964, Reservoir sedimentation, in Chow, V. T., ed., Handbook of applied hydrology: New York, McGraw-Hill Book Co., p. 17-1 to 17-34.

Guy, H. P., 1969, Laboratory theory and methods for sediment analysis: U.S. Geological Survey Techniques of Water-Resources Investigations, Book 5, Chapter C1, 58 p.

Guy, H. P., and Norman, V. W., 1970, Field methods for measurement of fluvial sediment: U.S. Geological Survey Techniques of WaterResources Investigations, Book 3, Chapter C2, $59 \mathrm{p}$.

Harper, E. L., 1953, Semimicro determination of dissolved oxygen: Analytical Chemistry, v. 25, p. 187-188.

Hilsenhoff, W. L., 1977, Use of arthropods to evaluate water quality of streams: Wisconsin Department of Natural Resources Technical Bulletin 100, p. 1-15.

Hunt, R. L., Brynildson, O. M., and McFadden, J. T., 1962, Effects of angling regulations on a brook trout fishery: Madison, Wisconsin Conservation Department Technical Bulletin No. $26,58 \mathrm{p}$.

Komura, Saburo, and Simmons, D. B., 1967, River-bed degradation below dams: Journal of the Hydraulics Division, ASCE, Proceedings Paper 5335, v. 93, p. 1-14.

Leopold, L. B., Wolman, M. G., and Miller, J. P., 1964, Fluvial processes in geomorphology: San Francisco, W. N. Freeman and Co., 522 p.

Martin, Lawrence, 1932, The physical geography of Wisconsin: Madison, Wisconsin Geological and Natural History Survey, 608 p.

Mason, J. W., Brynildson, O. M., and Degurse, P. E., 1966, Survival of trout-fed dry and meatsupplemented dry diets: Progressive Fish Culturist, v. 28, p. 187-192.

McFadden, J. T., 1961, A population study of brook trout, Salvelinus fontinalis: Wildlife Monographs, no. 7, 73 p.

McFadden, J. T., and Cooper, E. L., 1962, An ecological comparison of six populations of brown trout (Salmo trutta): Transactions of the American Fisheries Society, v. 91, p. 53-62.

McNeil, W. J., 1962, Variation in the dissolved oxygen content of intragravel water in four spawning streams of southeastern Alaska: U.S.
Fish and Wildlife Service, Special Scientific Report--Fisheries, no. 402, 15 p.

McNeil, W. J., and Ahnell, W. H., 1964, Success of pink salmon spawning relative to size of spawning bed materials: U.S. Fish and Wildlife Service Special Scientific Report--Fisheries, no. $469,15 \mathrm{p}$.

Porterfield, George, 1972, Computation of fluvialsediment discharge: U.S. Geological Survey Techniques of Water-Resources Investigations, Book 3, Chapter C3, $66 \mathrm{p}$.

Seegrist, D. W., and Gard, Richard, 1972, Effects of floods on trout in Saghen Creek, California: Transactions of the American Fisheries Society, v. 101, p. 478-482.

Silver, S. J., Warner, C. E., and Doudoroff, Peter, 1963, Dissolved oxygen requirements of developing steelhead trout and chinook salmon embryos at different water velocities: Transactions of the American Fisheries Society, v. 92, p. 327-343.

Thwaites, F. T., 1956, Glacial features of Wisconsin: Wisconsin Geological and Natural History Survey map, scale 1:1,000,000.

U.S. Environmental Protection Agency, 1976, Quality criteria for water: Washington, D.C., U.S. Environmental Protection Agency, 256 p.

U.S. Geological Survey, 1977, Water resources data for Wisconsin, 1976: U.S. Geological Survey Water-Data Report WI-76-1, 596 p.

---1978, Water resources data for Wisconsin, 1977: U.S. Geological Survey Water-Data Report WI-77-1, $639 \mathrm{p}$.

---1979, Water resources data for Wisconsin, 1978: U.S. Geological Survey Water-Data Report WI-78-1, $500 \mathrm{p}$.

---1980, Water resources data for Wisconsin, 1979: U.S. Geological Survey Water-Data Report WI-79-1, $514 \mathrm{p}$.

U.S. Soil Conservation Service, 1962, Soil survey manual: Washington, D.C., U.S. Department of Agriculture Handbook No. 18, 503 p.

U.S. Water Resources Council, 1977, Guidelines for determining flood flow frequency: Washington, D.C., Bulletin No. 17.

White, R. J., 1962, Trout reproduction: Madison, Wisconsin Conservation Department Annual Progress Report, 8 p.

---1964, Progress report on a study of the wild brown trout population and its habitat in Black Earth Creek, Wisconsin: Madison, University of Wisconsin, unpublished MS thesis, $109 \mathrm{p}$.

Williams, G. P., 1978, Bankfull discharge of rivers: Water Resources Research, v. 14, p. 1, 141-1, 154.

Wolman, M. G., and Leopold, L. B., 1957, River flood plains: Some observations on their formation: U.S. Geological Survey Professional Paper 282-C, p. 87-109. 